\title{
Nonassociated Gas Resources in Low-Permeability Sandstone Reservoirs, Lower Tertiary Wasatch Formation, and Upper Cretaceous Mesaverde Group, Uinta Basin, Utah
}

\section{Topical Report}

Thomas D. Fouch

James W. Schmoker

Lynn E. Boone

Craig ]. Wandrey

Robert A. Crovelli

William C. Butler

August 1994

Work Performed Under Interagency Agreement No.: DE-AT21-93MC30139

For

U.S. Department of Energy

Office of Fossil Energy

Morgantown Energy Technology Center

Morgantown, West Virginia

By

U.S. Department of Interior

U.S. Geological Survey

Lakewood, Colorado 


\section{DISCLAIMER}

This report was prepared as an account of work sponsored by an agency of the United States Government. Neither the United States Government nor any agency thereof, nor any of their employees, makes any warranty, express or implied, or assumes any legal liability or responsibility for the accuracy, completeness, or usefulness of any information, apparatus, product, or process disclosed, or represents that its use would not infringe privately owned rights. Reference herein to any specific commercial product, process, or service by trade name, trademark, manufacturer, or otherwise does not necessarily constitute or imply its endorsement, recommendation, or favoring by the United States Government or any agency thereof. The views and opinions of authors expressed herein do not necessarily state or reflect those of the United States Government or any agency thereof.

This report has been reproduced directly from the best available copy.

Available to DOE and DOE contractors from the Office of Scientific and Technical Information, 175 Oak Ridge Turnpike, Oak Ridge, TN 37831; prices available at (615) 576-8401.

Available to the public from the National Technical Information Service, U.S. Department of Commerce, 5285 Port Royal Road, Springfield, VA 22:161; phone orders accepted at (703) $487-4650$. 


\section{DISCLAIMER}

Portions of this document may be illegible in electronic image products. Images are produced from the best available original document. 


\title{
Nonassociated Gas Resources in Low-Permeability Sandstone Reservoirs, Lower Tertiary Wasatch Formation, and Upper Cretaceous Mesaverde Group Uinta Basin, Utah
}

\section{Topical Report}

\author{
Thomas D. Fouch \\ James W. Schmoker \\ Lynn E. Boone \\ Craig ]. Wandrey \\ Robert A. Crovelli \\ William C. Butler
}

Work Performed Under Interagency Agreement No.: DE-AT21-93MC30139

\author{
For \\ U.S. Department of Energy \\ Office of Fossil Energy \\ Morgantown Energy Technology Center \\ P.O. Box 880 \\ Morgantown, West Virginia 26507-0880 \\ By \\ U.S. Department of Interior \\ U.S. Geological Survey \\ P.O. Box 25046 \\ Lakewood, Colorado 80225-0046
}


This page intentionally left blank. 


\section{Contents}

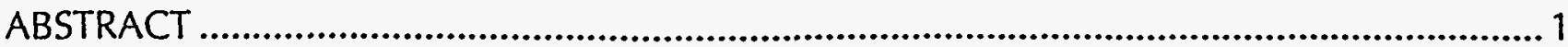

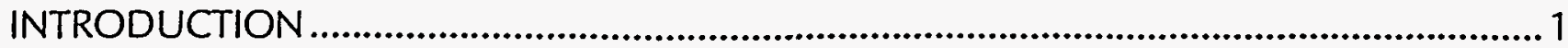

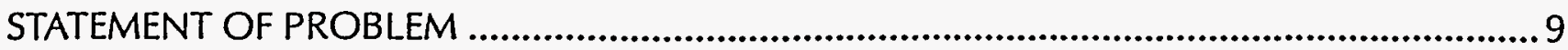

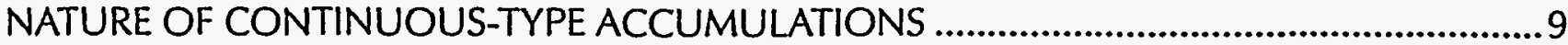

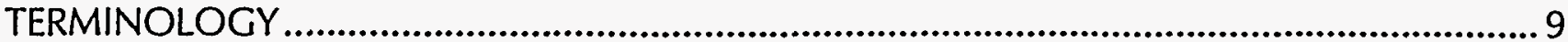

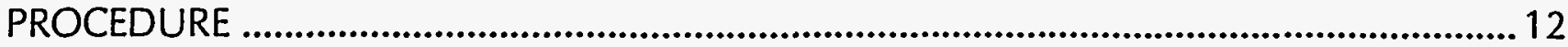

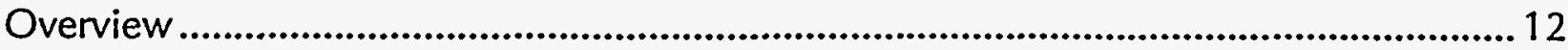

Represent Continuous-Type Accumulations by Plays ...................................................12

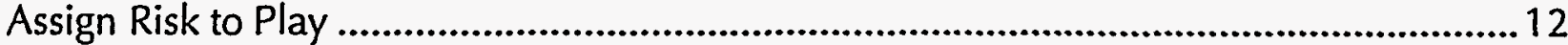

Estimate Number of Untested Cells in Play ................................................................13

Estimate Success Ratio for Untested Cells of Play ...............................................................13

Establish Estimated Ultimate Recovery (EUR) Probability Distribution for Productive,

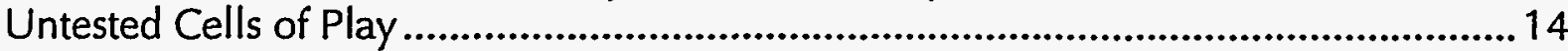

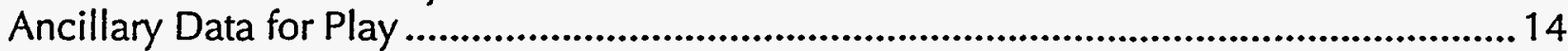

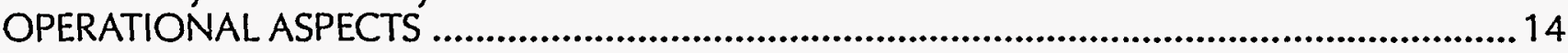

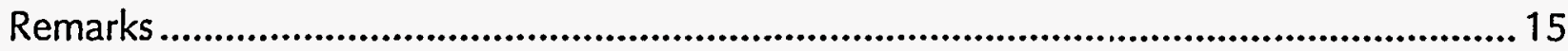

PROBABILISTIC METHODOLOGY FOR ASSESSMENT OF PETROLEUM RESOURCES FROM CONTINUOUS-TYPE ACCUMULATIONS ….......................................................... 15

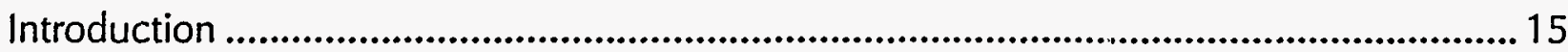

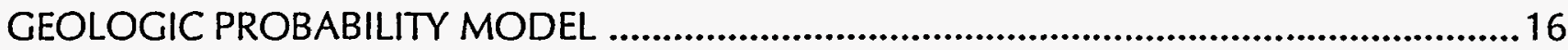

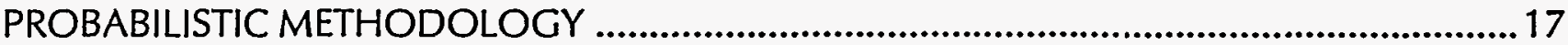

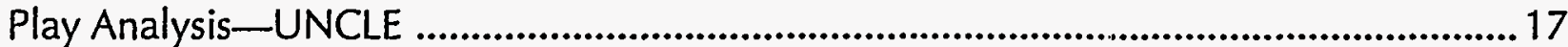

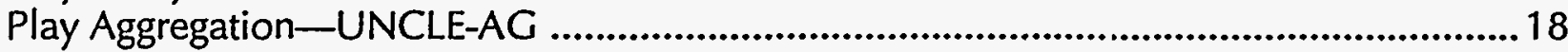

Relationship Between UNCLE and UNCLE-AG ................................................................20

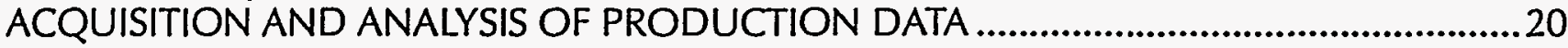

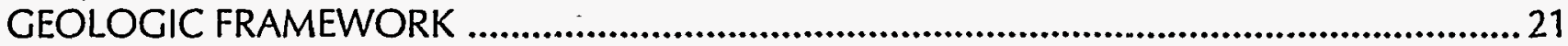

Upper Cretaceous Mesaverde Group and Associated Rocks ................................................22

Paleocene and Eocene Wasatch Formation and Associated Rocks ................................. 21

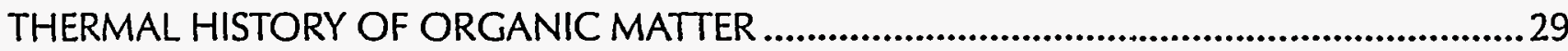

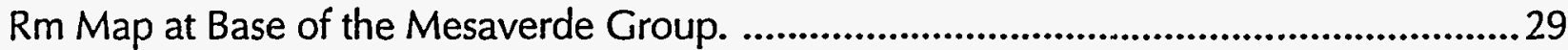

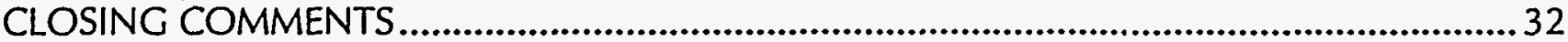

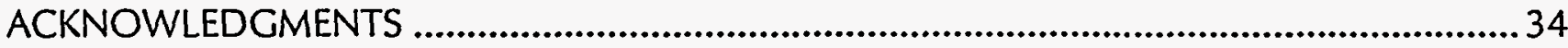

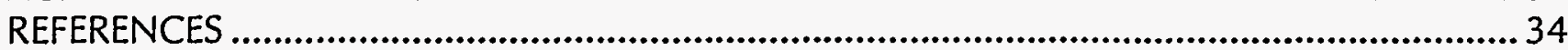

APPENDIX A-PLAY DEFINITIONS, STRATIGRAPHIC COMPONENTS, EUR

DISTRIBUTIONS, AND ANCILLARY DATA ..................................................................

APPENDIX B-GUIDELINES FOR COMPLETING DATA FORM FOR ASSESSMENT OF

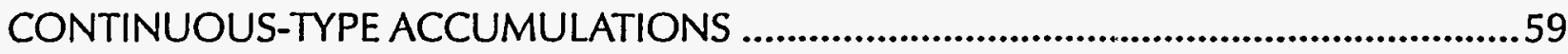

\section{List of Tables and Figures}

Table 1. Resources (potential additions to reserves)(TCF) Nonassociated Gas............................................ 2

Figure 1. Map of Uinta Basin, Utah showing generalized area of plays 2015 and 2016, gas-saturated strata in the lower Tertiary Wasatch Formation.

Figure 2. Map of Uinta Basin, Utah showing generalized area of play 2017 , reservoirs in which both gassaturated strata and rocks with gas/water contacts seem to coexist in the lower Tertiary Wasatch Formation 


\section{List of Tables and Figures}

\section{(Continued)}

Figure 3. Map of Uinta Basin, Utah showing generalized area of play 2018, gas-saturated strata in the Upper Cretaceous Mesaverde Group < 15,000 ft ................................................................................ 6

Figure 4. Map of Uinta Basin, Utah showing generalized area of play 2019, reservoirs in which both gassaturated strata and rocks with gas/water contacts seem to coexist in the Upper Cretaceous Mesaverde Group

Figure 5. Map of Uinta Basin, Utah showing generalized area of play 2018, gas-saturated strata in the Upper Cretaceous Mesaverde Group > 15,000 ft

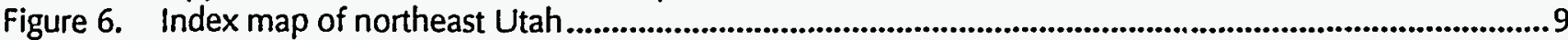

Figure 7. Index map of the Uinta and Piceance basins showing area of principal hydrocarbon accumulations in sedimentary rocks

Figure 8. Diagram showing geologic column and a summary of geologic events for the area of the central part of the Uinta Basin, Utah.

Figure 9. Geologic setting of continuous-type gas or oil accumulations relative to discrete accumulations in structural or stratigraphic traps.

Figure 10. Flow diagram emphasizing geologically based portion of protocol (above wavy line) used to assess continuous-type gas and oil accumulations

Figure 11. Sketch depicting a continuous-type play as a collection of cells of area equal to typical spacing expected for wells of the play

Figure 12. Illustration using hypothetical data of estimated ultimate recovery (EUR) probability distribution for productive, untested cells of a continuous-type play

Figure $\mathrm{C1}$. Flowchart for analytic method of play analysis (UNCLE).

Figure C2. Flowchart for analytic method of play aggregation (UNCLE-AG).

Figure 13. Production rate curve (thousands of cubic feet per day versus year) for a Wasatch producer located in the Uinta Basin, Utah

Figure 14. Estimated ultimate recovery (EUR) distribution of a 45 well sample set representing the untested cells in a Wasatch, Uinta Basin play

Figure 15. Albian to middle Eocene chronostratigraphic diagram along cross section line illustrating nomenclature and temporal relations of major strata from the Sanpete Valley of central Utah to the Book Cliffs of eastern Utah via the southern part of the Uinta Basin, Utah

Figure 16. Stratigraphic cross section of upper Campanian through lowest Eocene rocks extending from Price Canyon to Natural Buttes area showing lithofacies and interpreted depositional environments.

Figure 17. Paleogeographic map including Mesaverde Group depositional-facies at the time of the Campanian marine fossil zone of Baculites asperiformis and its nonmarine extensions.................... 26

Figure 18. Paleogeographic map including Mesaverde Group depositional-facies map) at the time of the Campanian marine fossil zone of Baculites perplexus and its nonmarine extensions

Figure 19. Paleogeographic map including Mesaverde Group depositional-facies at the time of the Campanian marine fossil zone of Didymoceras nebrascense and its nonmarine extensions .............. 27

Figure 20. Paleogeographic map including Mesaverde Group depositional-facies at the time of the Campanian marine fossil zone of Baculites cuneatus and its nonmarine extensions

Figure 21. Stratigraphic diagram B-B' that extends east from the Altamont-Bluebell oil field to the Red Wash and Hells Hole areas of the east end of the basin by way of Gate Canyon and Thompson Canyon of the basin's south flank

Figure 22. Paleogeographic map including depositional-facies of a zone consisting of beds adjacent and laterally equivalent to the lower marker of the Paleocene and Eocene Flagstaff Member of the Green River Formation

Figure 23. Paleogeographic map including depositional-facies in a zone consisting of beds adjacent and laterally equivalent to the Paleocene-Eocene boundary

Figure 24. Paleogeographic map including depositional-facies in a zone consisting of beds adjacent and laterally equivalent to the middle marker of the Green River Formation

Figure 25. Cross section $A-A^{\prime}$ which extends from outcrops on the southwest flank of the Uinta Basin, through Duchesne and Altamont-Bluebell oil fields, to the north-central part of the basin

Figure 26. Vitrinite reflectance $(\mathrm{Rm})$ map showing thermal maturity on the base of the Mesaverde Group, Uinta Basin, Utah. 


\title{
NONASSOCIATED GAS RESOURCES IN LOW-PERMEABILITY SANDSTONE RESERVOIRS, LOWER TERTIARY WASATCH FORMATION, AND UPPER' CRETACEOUS MESAVERDE GROUP, UINTA BASIN, UTAH
}

\author{
by \\ Thomas D. Fouch, James W. Schmoker, Lynn E. Boone, Craig J. Wandrey, \\ Robert A. Crovelli and William C. Butler \\ Contract No. DE-AT21-93MC30139
}

\section{ABSTRACT}

The U.S. Geological Survey recognizes six major plays for nonassociated gas in Tertiary and Upper Cretaceous low-permeability strata of the Uinta Basin, Utah. For purposes of this study, plays without gas/water contacts are separated from those with such contacts (i.e., continuous-saturationaccumulations). Continuous-saturation accumulations are essentially single fields, so large in areal extent and so heterogeneous that their development cannot be properly modeled as field growth. Fields developed in gas-saturated plays are not restricted to structural or stratigraphic traps and they are developed in any structural position where permeability conduits occur such as that provided by natural open fractures. Other fields in the basin have gas/water contacts and the rocks are water-bearing away from structural culmination's. The plays can be assigned to two groups. Group I plays are those in which gas/water contacts are rare to absent and the strata are gas saturated. Group II plays contain reservoirs in which both gas-saturated strata and rocks with gas/water contacts seem to coexist. Most units in the basin that have received a Federal Energy Regulatory Commission (FERC) designation as tight are in the main producing areas and are within Group I plays. Some rocks in Group II plays may notmeetFERC requirements astight reservoirs. However, we suggest that in the Uinta Basin that the extent of low-permeability rocks, and therefore resources, extends well beyond the limits of current FERC designated boundaries for tight reservoirs.

Potential additions to gas reserves from gas-saturated tight reservoirs in the Tertiary Wasatch Formation and Cretaceous Mesaverde Group in the Uinta Basin, Utah is 10 TCF (Group I sum of means of plays). If the potential additions to reserves in strata in which both gas-saturated and free water-bearing rocks exist (Group II plays sum of means) are added to those of Group I plays, the volume is $13 \mathrm{TCF}$. Of this latter number, as much as $7.4 \mathrm{TCF}$ will be recovered from Tertiary reservoirs and 5.8 TCF from Upper Cretaceous rocks.

\section{INTRODUCTION}

Oil and gas compositions indicate that at least three petroleum systems occur within the greater Uinta-Piceance basin. The nonassociated gas fields produce mostly from Messozoic reservoir rocks with some gas migrating into the overlying Tertiary strata. ${ }^{*}$ Most of this gas is thought to originate from the underlying Cretaceous Mancos Formation and (or) Mesaverde Group, and it is interpreted to be part of one or more gas systems. The second petroleum system is represented by the relatively high sulfur oil in the Ashley Valley and Rangely oil fields. This oil probably originated from the Phosphoria Formation source rock sometime in late Mesozoic time. In the third system, production from the Green River Petroleum system is largely restricted to the Uinta Basin in northeastern Utah. The Green River Formation contains the source rocks as well as most of the reservoir and seal rocks (some in Wasatch Formation) in this prolific petroleum system, and levels of maturity have been sufficient to generate exceptionally large volumes of paraffinic high pourpoint oil and wet gas. Currently, economically viable oil in the Uinta Basin is recovered from the subsurface where the oil is above pour point temperatures and is moveable, and where strata are especially porous and permeable.

The gas accumulations in Tertiary and Upper Cretaceous low-permeability strata of the Uinta Basin were grouped into plays, that is, hydrocarbon accumulations with common characteristics. The play has as its essence the notion that variance in stratal or rock properties, generally factors involving petroleum source, reservoir, and trapping units, has served to isolate accumulations to restricted areas. If conditions are favorable for discovery and exploitation, the accumulations may become fields. In other words, groups of fields and undiscovered hypothesized 
Table 1. Resources (potential additions to reserves)(TCF) Nonassociated Gas

\begin{tabular}{lllllll}
\hline Mean & F95 & F75 & - F50 & - F25 & F05 & $\begin{array}{c}\text { EUR/cell } \\
\text { (mean) }\end{array}$ \\
\hline
\end{tabular}

Some of means of all Wasatch and Mesaverde Plays

(Wasatch Plays 2015, 2016, 2017 and Mesaverde Plays 2018, 2019 \& 2020)

13.2

Some of means of Wasatch and Mesaverde Plays without Gas/Water Contacts

(Wasatch Plays 2015 \& 2016 and Mesaverde Plays 2018 \& 2020)

10.1

Some of means of Wasatch Plays 2015 and 1016 without Gas/Water Contacts

5.75

Wasatch Play 2015 without Gas/Water Contacts

4.65 see Appendix A for analysis by plausible scenarios

Wasatch Play 2016 without Gas/Water Contacts

1.1 See Appendix A for analysis by plausible scenarios

Wasatch Play 2017 with Gas/Water Contacts
1.62
0.54
0.94
1.34
3.5
0.74

Some of means of all Wasatch Plays $(2015,1016, \& 2017)$

\subsection{7}

Some of means of Mesaverde Plays 2018 \& 2020 Without Gas/Water Contacts

\subsection{5}

Mesaverde Play 2018 Without Gas/Water Contacts
3.78
1.83
2.09
3.50
4.57
6.69
1.06

Mesaverde Play 2019 With and Without Gas/Water Contacts
1.48
0.5
0.86
1.3
1.85
3.21
0.59

Mesaverde Play 2020 Without Gas/Water Contacts
0.57
0.25
0.39

0.52

0.70

1.08

1.06

Some of means of all Mesaverde Plays $(2018,2019,2020)$

\subsection{3}

accumulations with similar geologic and engineering (production) characteristics constitute a play. These common characteristics or factors establish a basis for understanding such that their presence can be predicted in undrilled and otherwise unexplored areas, and so that the amount of oil and gas resources in the undrilled areas can be estimated.
For purposes of this study, gas plays without gas/ water contacts were separated from those with such contacts. Fields developed in "gas-saturated" plays are not restricted to structural highs and they are developed in any structural position where natural open fractures occur. Field boundaries ignore local structural attitudes. Other gas-bearing fields in the 
Uinta Basin have gas/water contacts and the rocks are water-bearing away from structural culminations.

Six major plays for nonassociated gas in lowpermeability rocks were identified in Tertiary and Upper Cretaceous low-permeability strata of the Uinta Basin. The six are: number 2015, the main Wasatch Formation play; number 2016, the westem extension of the Wasatch Formation play; number 2017, The Wasatch Formation Transitional play; number 2018, the Basin Flank Mesaverde Group play; number 2019, The Mesaverde Group Transition play; and number 2020, the Synclinal Low Mesaverde Group play (Figs. 1-5). The plays can be assigned to two groups. Group I plays 2015, 2016, 2018, and 2020 are those in which gas/water contacts are rare to absent and the strata are gas saturated. Group II plays 2017 and 2019 contain reservoirs in which both gas-saturated strata and those with gas/water contacts seem to coexist. The plays meet the needs of this study but could be further subdivided for other purposes.

The FERC Order 99 (1980) defined a tight reservoir as one whose in situ permeability throughout the pay or gas producing section is 0.1 md or less to gas (exclusive of fracture permeability). Many Uinta Basin gas reservoirs have been described as being tight and have qualified as being tight, although core-plug porosity values for these tight reservoirs vary greatly and range from 1-16 percent (Boardman, C.R., and C.F. Knutson, 1980; Knutson, C.T., Hodges, L.T., and Righter, S.B., 1981; Keighin and Fouch, 1981; Fouch 1985; Pitman, J.K., Anders, D.E., Fouch, T.D., and Nichols, D.J., 1986).

Some rocks in Group II plays may not meet FERC requirements as "tight" reservoirs. Mostunitsin the basin that have received a FERC designation are in the main producing areas and are within Group I plays. However, we suggest that in the Uinta Basin, Utah the extent of low-permeability rocks, and therefore resources, extends well beyond the limits of FERC designated boundaries for tight reservoirs.

Gas-bearing Cretaceous and Tertiary strata have been identified in drill holes distributed over much of the eastern and north-central parts of Uinta Basin, Utah (Figs. 6 and 7). Most known accumulations of nonassociated gas are associated with fields that occur east of the GreenRiverwhere they are found within rocks of the Upper Cretaceous Mesaverde Group, uppermost Cretaceous to lower Eocene North.Hom Formation, and the Paleocene and Eocene Wasatch, Colton, and Green River Formations (Fig. 8).
The U.S. Geological Survey, at the request of the United States Department of Energy, was asked to characterize nonassociated gas in lower Tertiary Wasatch Formation and Upper Cretaceous Mesaverde Group reservoirs and to assess their resources. We did not assess gas associated with oil reservoirs. We have reported on the geologic habitat of the gas in a number of recent publications that serve with several additional sources as the primary source of our geologic models. Discussions of geologic considerations herein are restricted and gerierally limited to graphical presentations. The user is referred to Fouch et al. (1992a, 1992b, 1992c,), Harmann and MacMillan (1992), MacMillan (1992), Nuccio et al. (1992), Osmond (1992), Rice et al. (1992), and Schmoker et al. (1992) for a more thorough discussion of the petroleum geology of the basin's low-permeability strata. Fouch et al. (1994) presents a discussion and evaluation of oil and gas resources in strata underlying Naval Oil Shale Reserves 1 and 3, Colorado, and Reserve 2, Utah. They provides data and ideas that are used hereirh, and their report includes an analyses of gas and oil in older Mesozoic and Paleozoic rocks in the region of the Uinta and Piceance basins. In addition, Fouch et al. (1994) provide data on play EUR distributions that are critical to this report. This report assesses Upper Cretaceous Campanian and Maastrichtian, and lower Tertiary gas-bearing rocks in the Uinta Basin with special emphasis on those units that contain gas in reservoirs that have been described as being tight. The report represents the second part of a two-report series that was prepared for the U.S. Department of Energy whose Westem Tight Gas Sandstone Program who cofunded much of this research in conjunction with the U.S. Geological Survey's Evolution of Sedimentary Basins, and Onshore Oil and Gas Programs.

Oil and gas compositions indicate that at least three petroleum systems occur within the greater Uinta-Piceance basin. The nonassociated gas fields produce mostly from Mesozoic reservoir rocks with some gas migrating into the overlying Tertiary strata. Most of this gas is thought to originate from the underlying Cretaceous Mancos Formation and (or) Mesaverde Group, and it is interpreted to be part of one or more gas systems. The second petroleum system is represented by the relatively high sulfur oil in the Ashley Valley and Rangely oil fields. This oil probably originated from the Phosphoria Formation source rock sometime in late Mesozoic time. In the third system, production from the Green River Petroleum system is largely restricted to the Uinta Basin in 


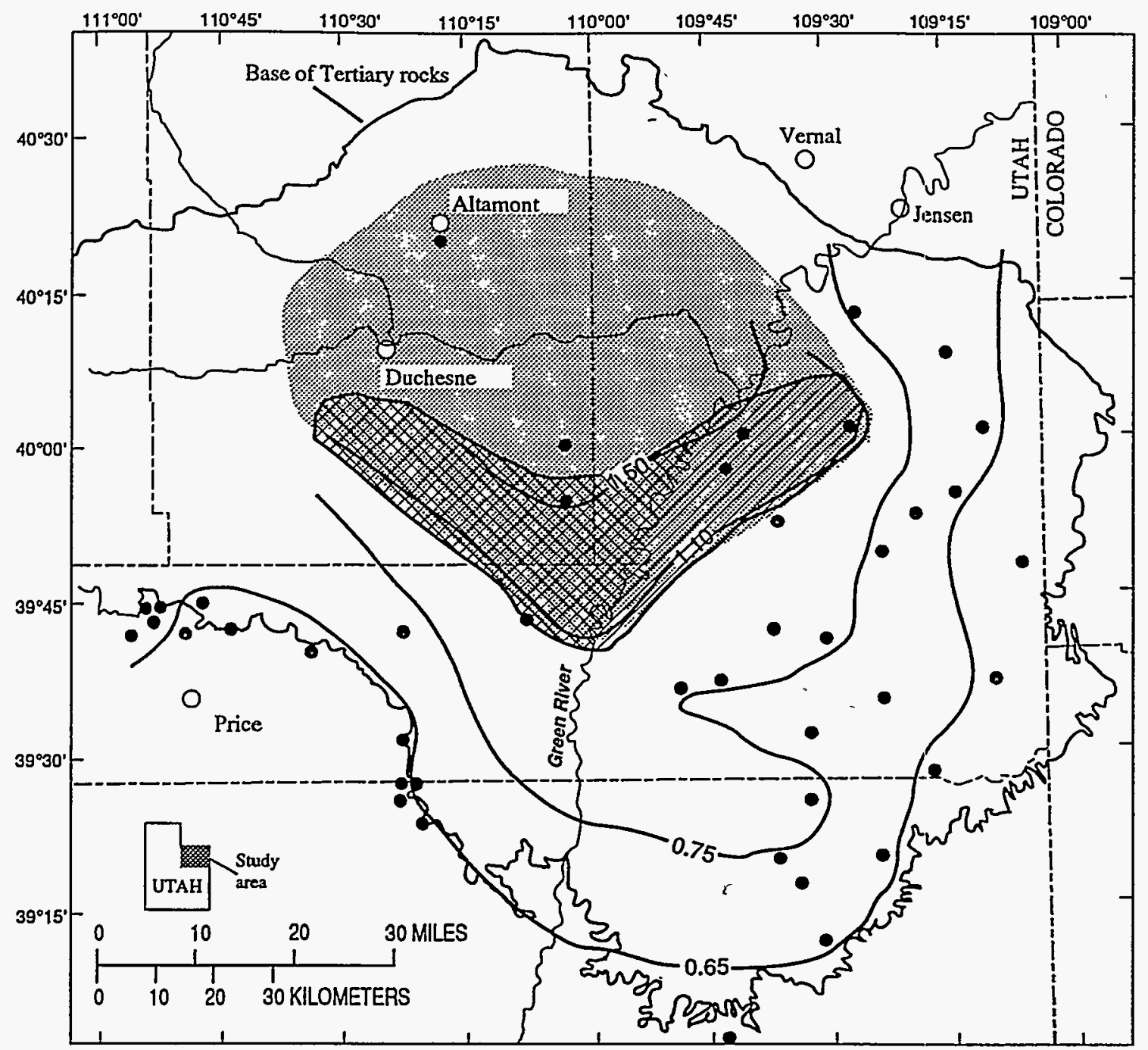

Plays 2015 \& 2016: Gas-Saturated Wasatch Formation

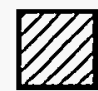

Area of Play 2015: Wasatch Production (includes Uteland Butte, Chapita, \& Buck Canyon zones) from this area:

Area of Play 2016: Wasatch Production (includes Uteland Butte, Chapita, \& Buck Canyon zones) from this area:

Area of maximum gas generation from Type III orgainic matter near the base of the Mesaverde Group (Ro > 1.10\%).

- Control point for measures of vitrinite reflectance

Figure 1. Map of Uinta Basin, Utah showing generalized area of plays 2015 and 2016, gas-saturated strata in the lower Tertiary Wasatch Formation. Play boundaries are approximate.

northeastem Utah. The Green River Formation con-

- tains the source rocks as well as most of the reservoir and seal rocks (some in Wasatch Formation) in this prolific petroleum system, and levels of maturity have been sufficient to generate exceptionally large volumes of paraffinic high pour-point oil and wet gas. Currently, economically viable oil in the Uinta Basin is recovered from the subsurface where the oil is above pour point temperatures and is moveable, and where strata are especially porous and permeable. 


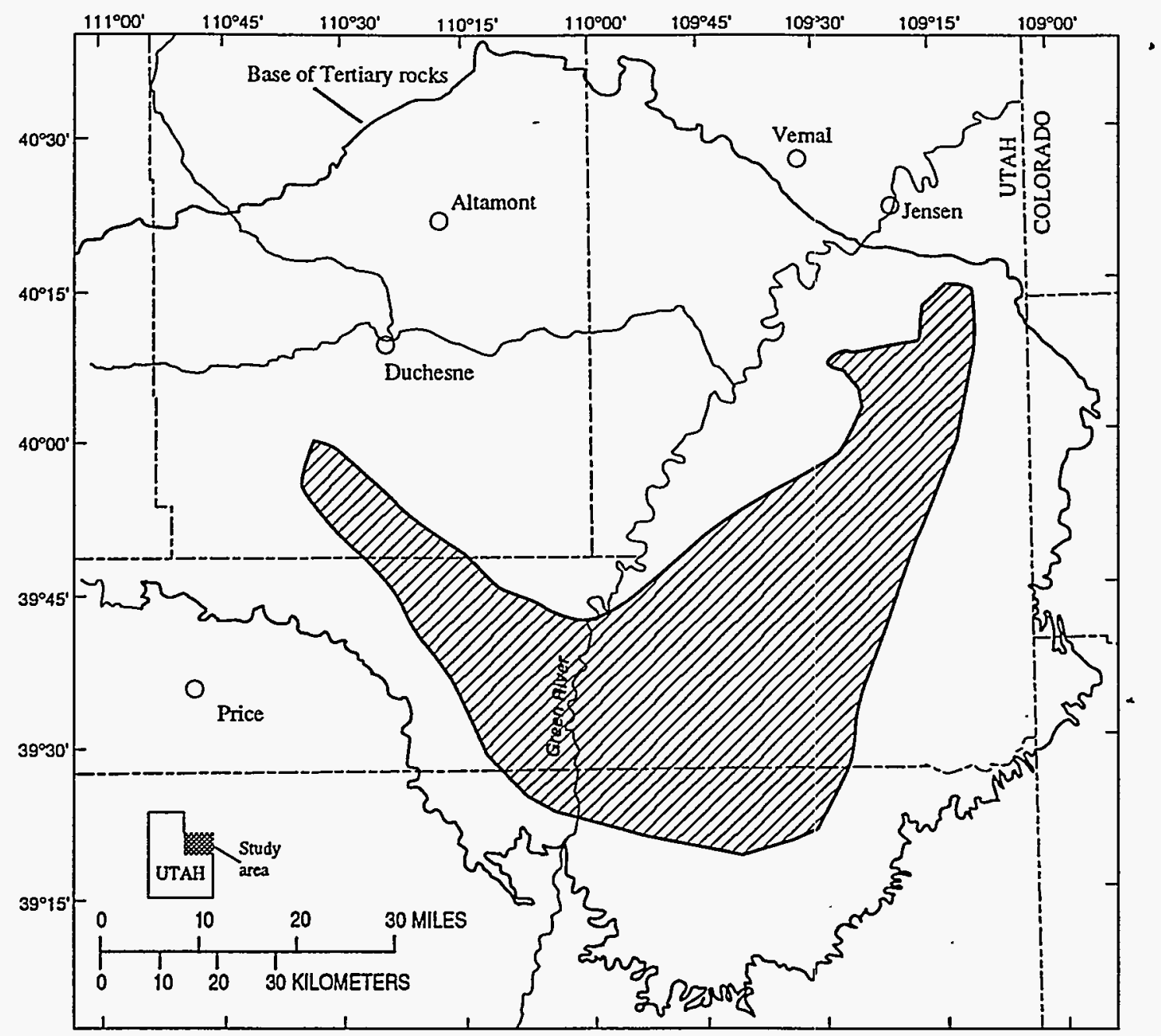

Play 2017: Gas with water contacts: Wasatch Formation

Area of Play 2017: Wasatch Production (includes Uteland Butte, Chapita, \& Buck Canyon zones):

Figure 2. Map of Uinta Basin, Utah showing generalized area of play 2017, reservoirs in which both gas-saturated strata and rocks with gas/water confacts seem to coexist in the lower Tertiary Wasatch Formation. Play boundaries are approximate.

Hydrocarbons that underlie the Uinta Basin, Utah were assigned to: Eastern Wasatch Gas-Saturated 2015; the westem extension of the Wasatch Formation play 2016; Wasatch Formation Transitional 2017; the Basin Flank Mesaverde Group 2018; Mesaverde Group Transitional 2019; and Mesaverde Deep Basinal 2020.

Eastern Wasatch Gas-Saturated Play 2015, Play 2016, and Play 2017 (Appendix A): These plays includes Paleogene fluvial and lacustrine strata commonly assigned to the Wasatch or Colton Formations in the southeast part of the Uinta Basin, Utah.
Of particular note is the absence of gas/water contacts from within the area of primary production at the Natural Buttes field. A key component of assignment of hydrocarbons to plays was their position relative to the line described by the surface projection of the vitrinite reflectance value $(\mathrm{Rm})>1.10$ at the base of the Mesaverde. The line serves to separate the Wasatch Formation into domains in which a region where free water seems to coexists with zones of continuous gas saturation (Play 2017) from those believed to be characterized be continuos-gas saturation (Plays 2015 


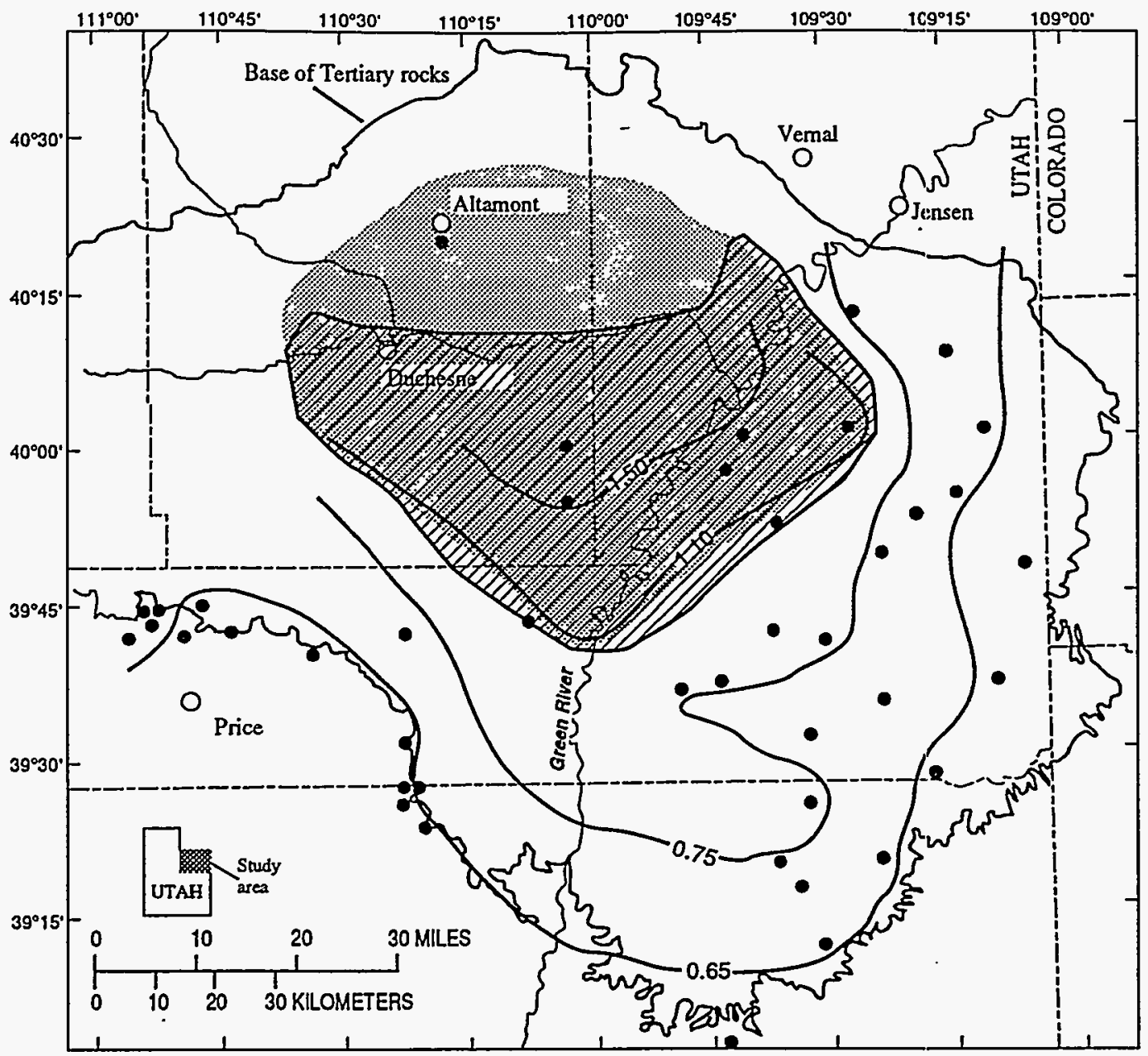

Play 2018: Basin flank Gas-Saturated Mesaverde $15,000 \mathrm{ft}$

Area of Play 2018: Mesaverde Group gas-saturated reservoirs at drilling depths near and less than 15,000 ft . Mesaverde Group strata include the Rim Rock, Castlegate, and Sego Sandstones, and the Blackhawk, Tuscher, Farrer, Price River, and Neslen Formations.

Area of maximum gas generation from Type III orgainic matter near the base of the Mesaverde Group (Ro > 1.10\%).

- Control point for measures of vitrinite reflectance that relatie to this play

Figure 3. Map of Uinta Basin, Utah showing generalized area of play 2018, gas-Saturated strata in the Upper Cretaceous Mesaverde Group < 15,000 ft. Play boundaries are approximate.

and 2016). The large Natural Buttes gas field serves as the core of play 2015 and it is developed above the area where gas is being generated in the underlying Mesaverde Group and rising directly to be trapped in reservoirs of the Wasatch Formation. As a result, source, reservoir rocks, and trap are in close proximity and drilling success is relatively high. Play 2016 is that region of continuous gas saturation where source and reservoir rocks are separated by an northwest thickening wedge of lower Tertiary strata and the resultant drilling success is not as high as that for play 2015.

Mesaverde Deep Basin Play 2020; Basin Flank Mesaverde Group Play 2018; The Mesaverde Group Transitional Play 2019 (Appendix A): The plays consist of mixed stratigraphic and structural accumulations of gas in sandstone reservoirs of the 


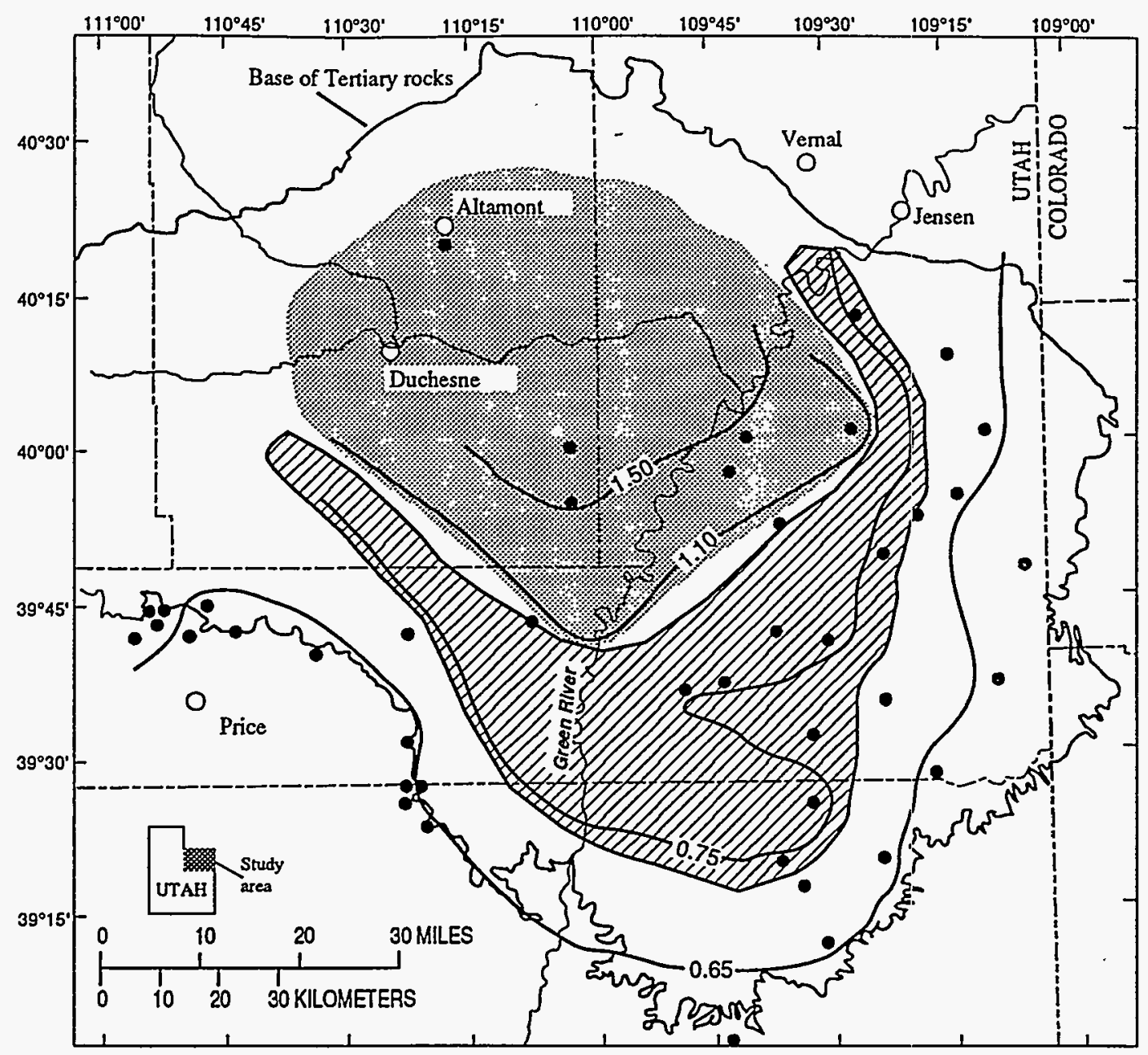

Play 2019: Cretaceous Mesaverde Gas-Water Transitional.

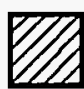

Area of Play 2019 : Mesaverde Group reservoirs at drilling depths near and less than15,000ft . Mesaverde Group strata include the Rim Rock, Castlegate, and Sego Sandstones, and the Blackhawk, Tuscher, Farrer, Price River, and Neslen Formations. Contains mixed water and gas-bearing strata.

Area of maximum gas generation from Type III orgainic matter near the base of the Mesaverde Group (Ro > 1.10\%).

Control point for measures of vitrinite reflectance that relate to this play

Figure 4. Map of Uinta Basin, Utah showinggeneralized area of play 2019, reservoirs in which both gas-saturated strata and rocks with gas/water contacts seem to coexist in the Upper Cretaceous Mesaverde Group. Play boundaries are approximate.

Upper Cretaceous Mesaverde Group. Reconstructions of the burial history of the strata and measures of vitrinite reflectance $(\mathrm{Rm})$, indicate that gas is currently being generated from source rocks within the Upper Cretaceous section. Of particular note is the absence of gas/water contacts from within the area of primary production from the Mesaverde at the Natural Buttes field. As mentioned earlier, a key component of assignment of hydrocarbons to plays was their position relative to the line described by the surface projection of the vitrinite reflectance value $(\mathrm{Rm})>1.10$ at the base of the Mesaverde. Again, the line serves to separate the Mesaverde into domains in which a region where free water seems to coexists with zones of continuous gas saturation (Play 2019) from those believed to be characterized be continuous-gas saturation (Plays 2018 and 2020). 


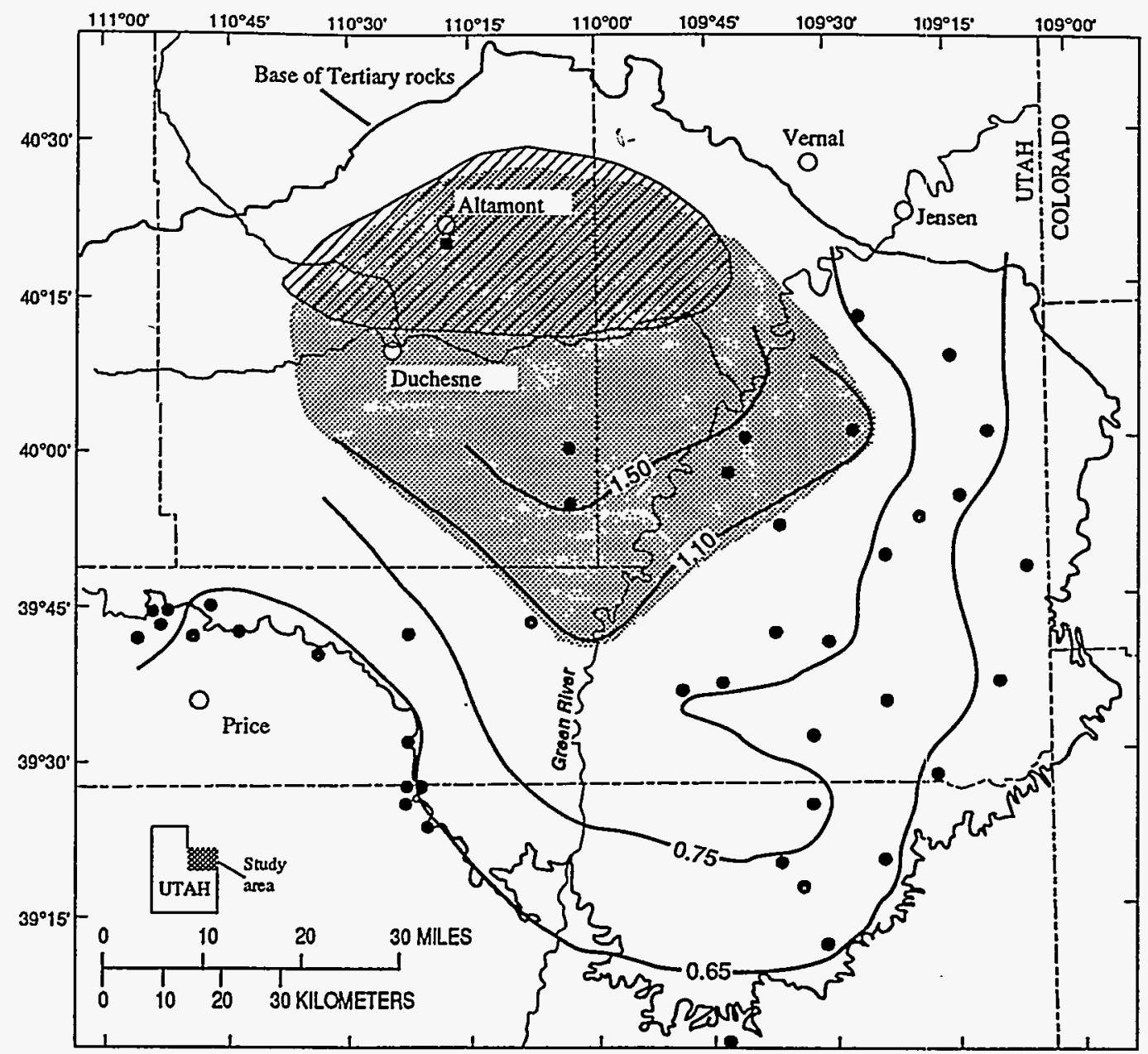

Play 2020: Gas-Saturated Deep Synclinal Low: Cretaceousi Mesaverde
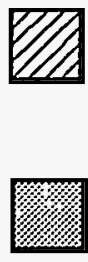

-

Area of Play 2020: Mesaverde Group reservoirs at drilling depths near and >15,000 ft . Accumulation spans the basin's synclinal axis. Mesaverde Group strata include the RimRock, Castlegate, and Sego Sandstones, and the Blackhawk, Tuscher, Farrer, Price River, and Neslen Formations.

Area of maximum gas generation from Type III orgainic matter near the base of the Mesaverde Group (Ro > 1.10\%).

Control point for measures of vitrinite reflectance that relate to this play

Figure 5. Map of Uinta Basin, Utah showing generalized area of play 2018, gas-saturated strata in the Upper Cretaceous Mesaverde Group $>15,000 \mathrm{ft}$. Play boundaries are approximate.

We believe that the rapid and ongoing generation of gas has led to the strata's high fluid-pressure gradi- ents, and that gradients more than $0.5 \mathrm{psi} / \mathrm{ft}$ can be expected in unexplored units. Porosity for units below $10,000 \mathrm{ft}$ is commonly below $10 \%$ and may be as low as 6 to $8 \%$. Many of these reservoirs will be characterized by values of matrix permeability less than $0.1 \mathrm{md}$ in situ to gas.

The composition of source rocks in the Upper Cretaceous (Type III organic matter-high oxygen to hydrogen ratio) units is such that most hydrocarbons generated from thena are gas. In addition, the 


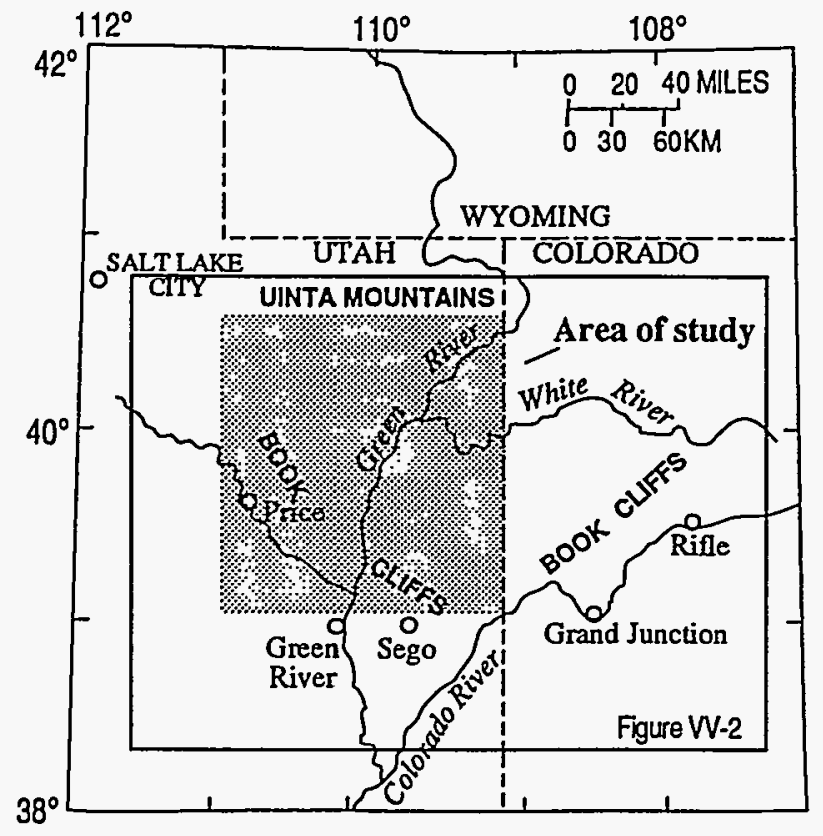

Figure 6. Index map of northeast Utah. Study area is shaded.

gas generating section appears to be continuously saturated and relatively free of water/gas contacts (Plays 2018 and 2020). These relations suggest that the regional extent of the gas-saturated zone will be much larger than that established by current drilling.

\section{STATEMENT OF PROBLEM}

The hydrocarbon accumulations addressed in this section are defined as "continuous-type" gas or oil accumulations, not significantly affected by hydrodynamic influences, for which assessment methodologies based on sizes and numbers of fields are not appropriate. We describe here the protocol that we used to assess potential additions to gas and oil reserves from continuous-type accumulations of the study areas.

Continuous-type accumulations are essentially single fields, so large in areal extent and so heterogeneous that their development cannot be properly modeled as field growth. Many assessment methodologies, such as that which will be used by the U.S. Geological Survey for conventional plays of their 1995 National Assessment, are inappropriate for continuous-type accumulations because such accumulations cannot be represented as groups of discrete, countable units (fields) delineated by down-dip hydrocarbon-water contacts.

\section{NATURE OF CONTINUOUS-TYPE ACCUMULATIONS}

Our definition of a continuous-type unconventional hydrocarbon accumulation is based on the observed setting and inferred dynamics of the accumulation; the definition does not incorporate criteria that are commonly associated with other types of unconventional accumulations such as low API gravity, low matrix permeability (tight), or special regulatory status. For example, tight-gas production may or may not be from a continuous-type accumulation that requires the special resource-assessment methodology described here.

The geologic setting typical of continuous-type accumulations is illustrated in Figure 9. Common geologic characteristics of a continuous-type accumulation include occurrence downdip from water-saturated rocks, lack of obvious trap and seal, crosscutting of lithologic boundaries, large areal extent, relątively low matrix permeability, abnormal pressure (high or low), and close association with source rocks. The boundary between a continuous-type accumulation and up-dip, water-saturated rocks (Fig. 9) may be transitional rather than abrupt.

Aspects of hydrocarbon production common to a continuous-type accumulation include large in-place hydrocarbon volume, low recovery factor, low water production, no truly dry holes, and a heterogeneous "hit or miss" character for production rates and ultimate recoveries of wells. Unlike undiscovered accumulations in discrete structural and stratigraphic traps, the locations of continuous-type accumulations are often known.

\section{TERMINOLOGY}

The assessment of continuous-type hydrocarbon accumulations is based on play analysis. In play analysis, an assessment area is partitioned into geologic plays and the plays are analyzed individually.

Selected definitions of particular importance to the assessment of continuous-type accumulations are presented here. These definitions should be viewed more as explanations than as inflexible technical rules.

Cell. A subdivision of a play with an area or size (acres, or $\mathrm{mi}^{2}=$ acres/640) equal to the typical spacing expected for wells of the play. Virtually all cells in a continuous-type accumulation are capable of producing some hydrocarbons. For purposes of this 


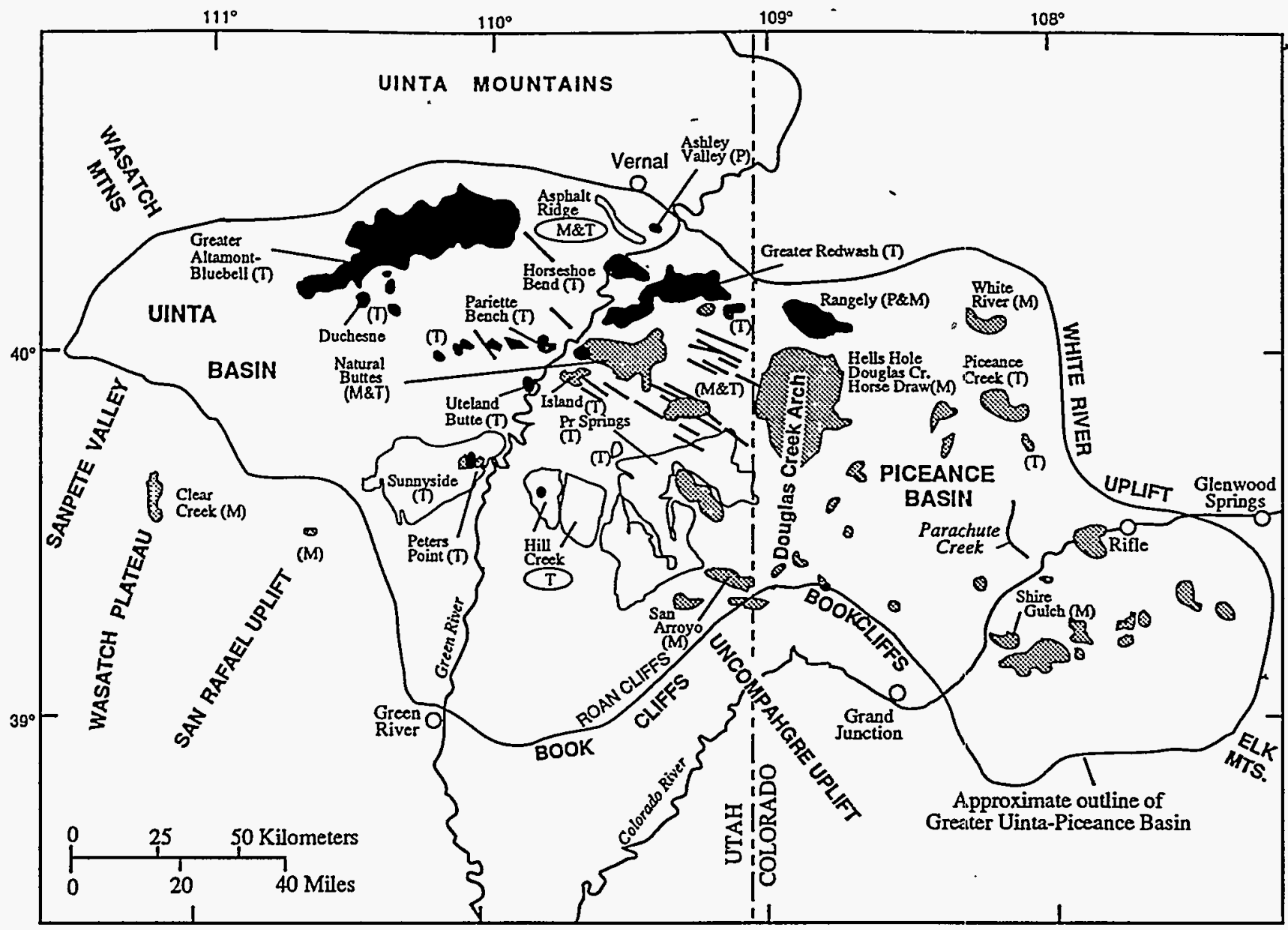

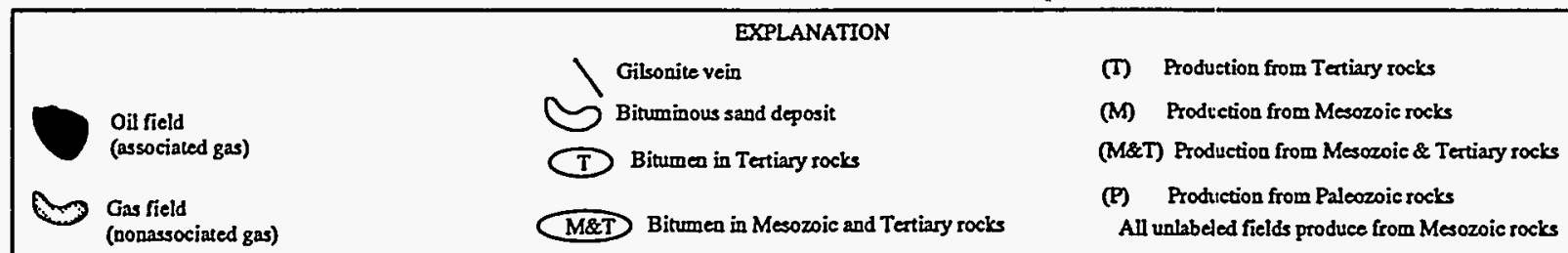

Figure 7. Index map of the Uinta and Piceance basins showing area of principal hydrocarbon accumulations in sedimentary rocks. Bitumen-bearing sandstones are abundant in surface exposures in l'egions between areas shown as tar sands.

discussion, a productive cell is one that contains at least one well for which production from the play is formally reported. A play with no productive cells is a hypothetical play. A nonproductive cell is one that contains one or more wells that evaluated the play, none of which was productive in the play. An untested cell is one that has not been evaluated by a well. The number of untested cells in a play equals the total number of cells minus the number of cells (productive - plus nonproductive) that have been evaluated.

Success ratio. The fraction (0-1.0) of untested cells in a play expected to be productive. The combination of success ratio and number of untested cells yields the number of productive, untested cells in a play.

Estimated ultimate recovery (EUR) probability distribution for productive, untested cells. A distribution that serves as a reference model for production from the productive, untested cells of a play. The EUR data of the distribution (barrels of oil or millions of cubic feet of gas) should be representative of productive cells yet to be drilled, rather than established production.

Play probability. The probability $(0-1.0)$ that untested cells of a play are capable of producing at least one million barrels of oil or six billion cubic feet 


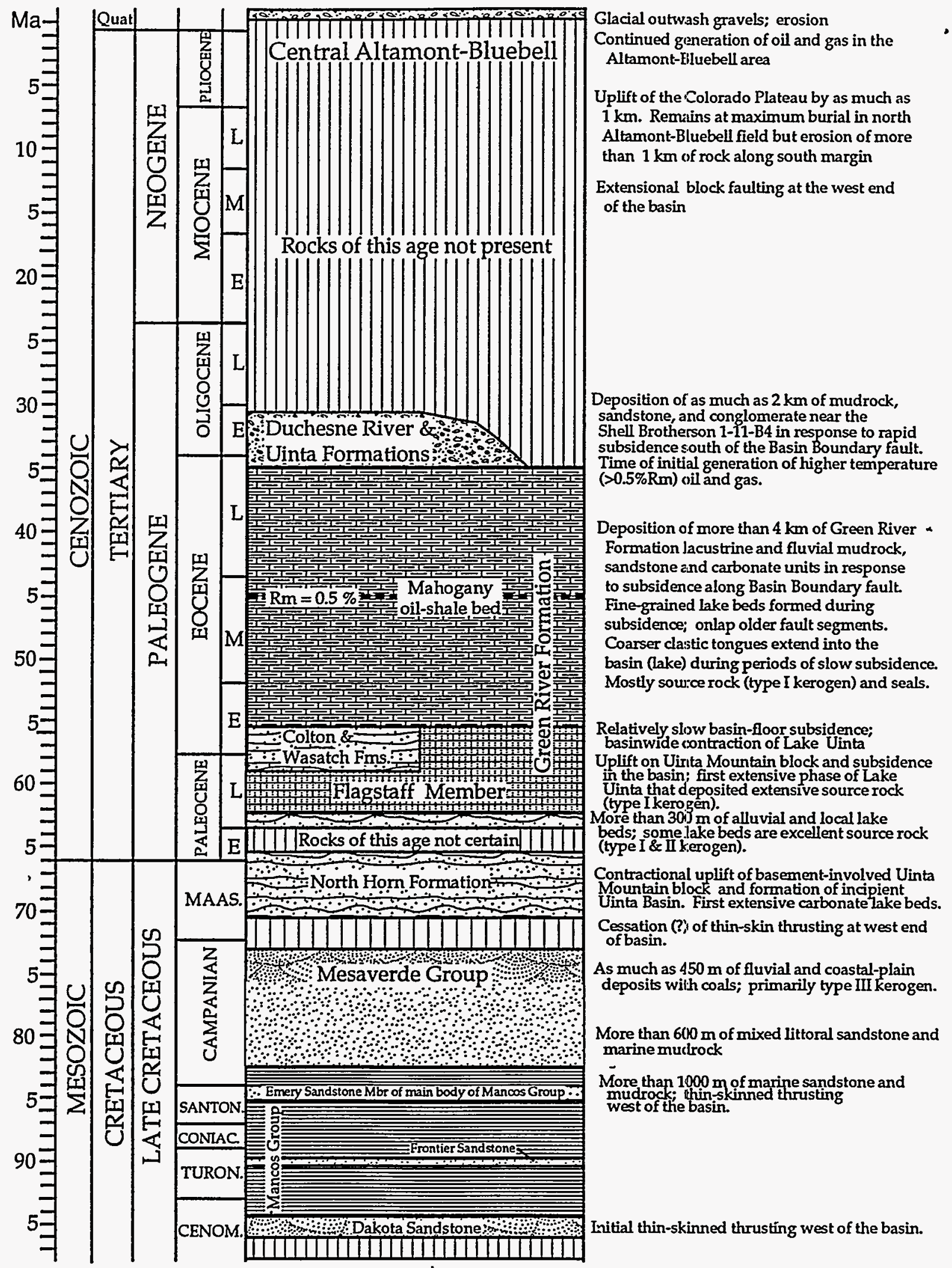

Figure 8. Diagram showing geologic column and a summary of geologic events for the area of the central part of the Uinta Basin, Utah. 


\section{SKEFCH OF CONTINUOUS-TYPPE

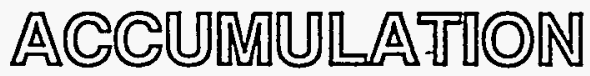

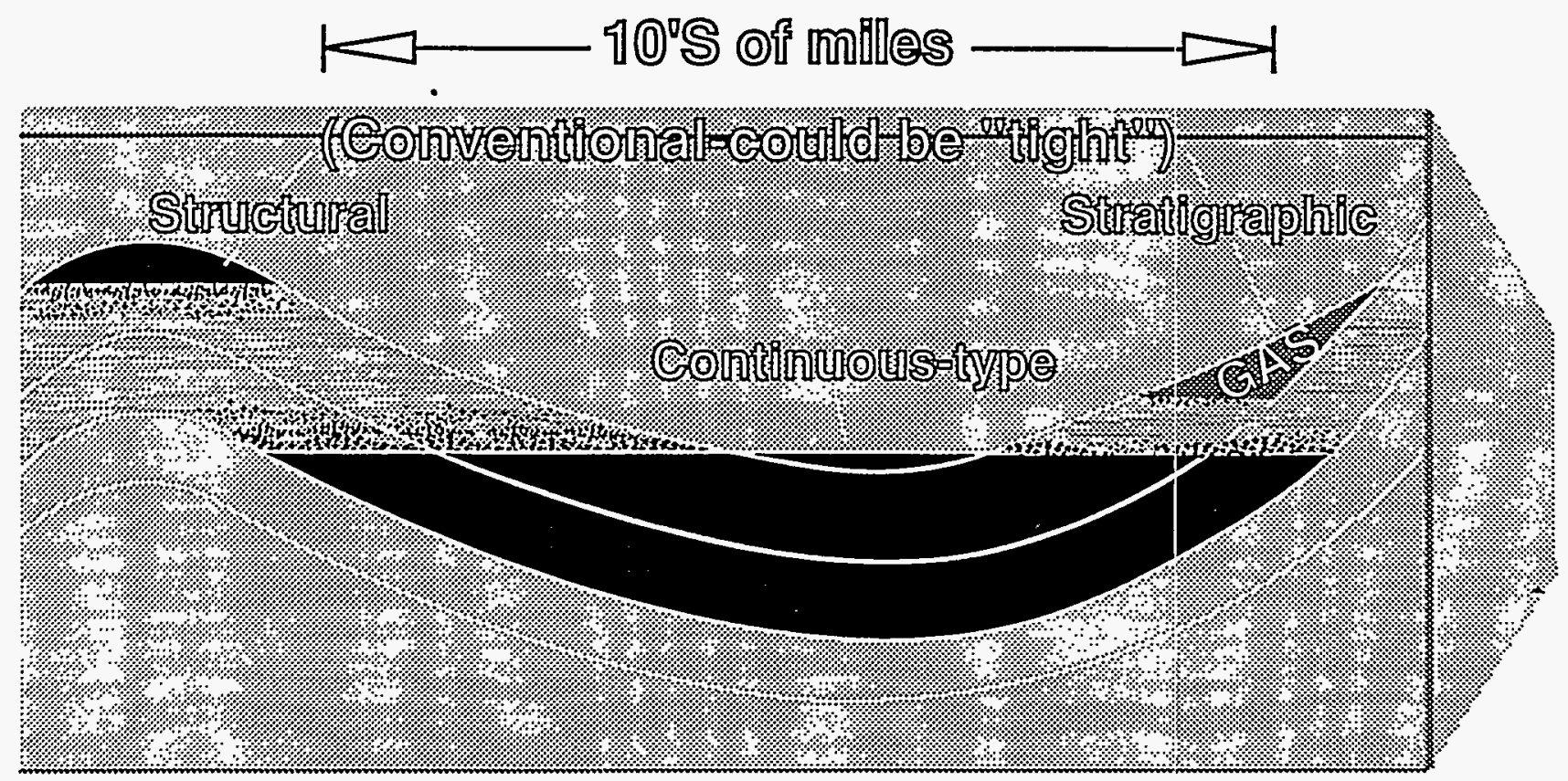

Figure 9. Geologic setting of continuous-type gas or oil accumulations relative to discrete accumulations in structural or stratigraphic traps.

of non-associated gas. These minimum production thresholds are the same as those that will be used by the U.S. Geological Survey for conventional plays (discrete accumulations) of their 1995 National Assessment.

\section{PROCEDURE}

\section{Overview}

The procedure outlined by the flow diagram of Figure 10 is straightforward in concept. A continuoustype accumulation is subdivided into plays, and geologic risk (play probability) is assigned to each play. A play is regarded as a collection of hydrocarbon-containing cells. The number of untested cells in a play and the fraction of untested cells expected to be productive (success ratio) are estimated using data from production studies or aspects of regional and local geology. The combination of success ratio and number of untested cells - yields the number of productive, untested cells in a play. Existing production is used as a reference model for potential production from productive cells yet to be drilled.

\section{Represent Continuous-Type Accumulations by Plays}

For the case of a continuous-type accumulation, the first step of the assessment (Fig. 10) is to represent the accumulation by a play or plays sufficiently homogeneous so that each play can be reasonably characterized by a single play probability, cell size, success ratio, and EUR probability distribution for productive, untested cells. Play boundaries must be concisely drawn because the assessment depends strongly on the area of the play. Each play is identified as either a gas play or an oil play. A gas to oil ratio of 20,000 cubic feet of gas per barrel of oil separates gas plays from oil plays.

\section{Assign Risk to Play}

A play probability is estimated for each play. Lower play probability equates to a greater geologic risk that untested cells are not capable of producing the minimum threshold volume; a play probability of 1.0 reflects geologic certainty that the minimum production 


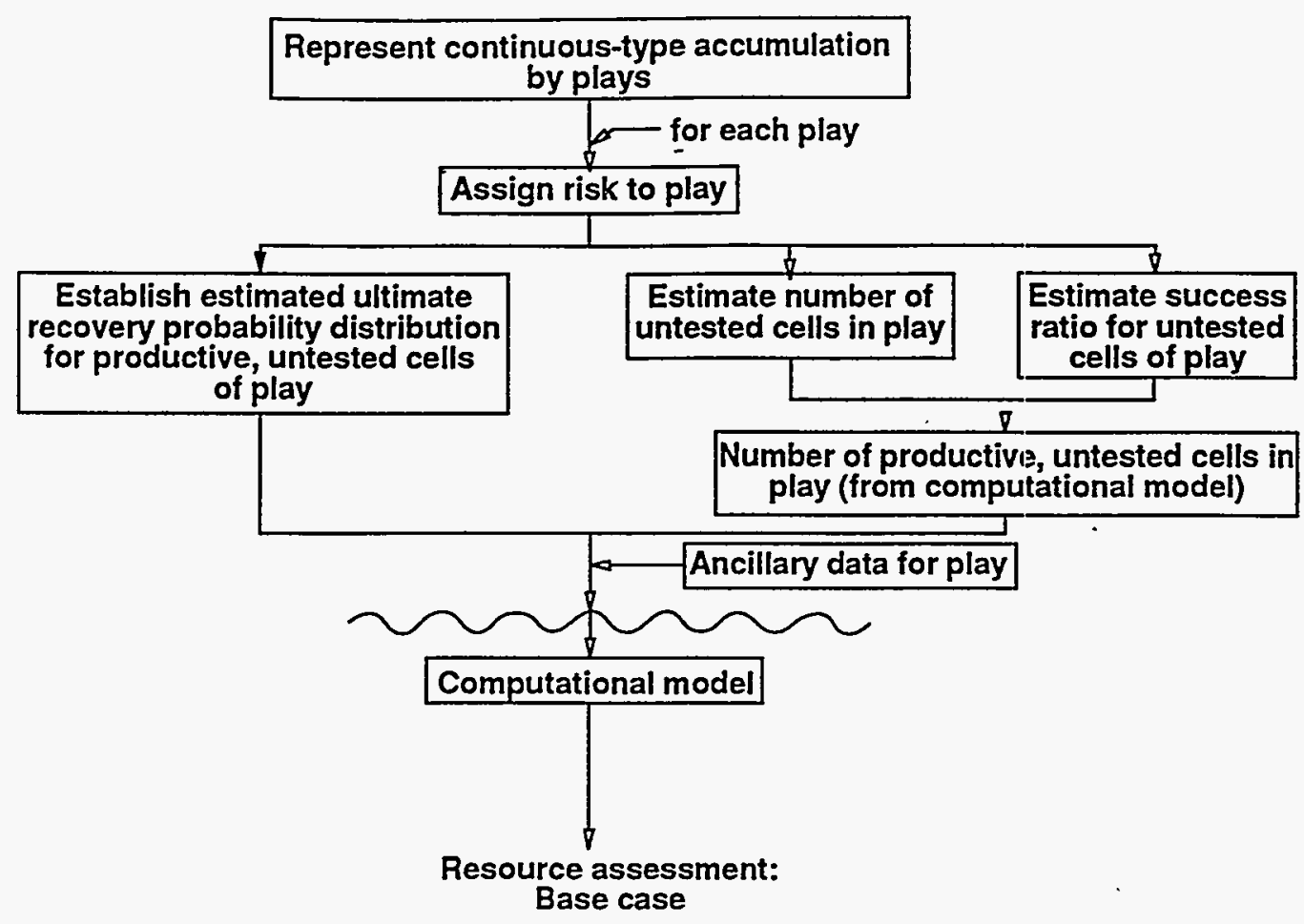

Figure 10. Flow diagram emphasizing geologically based portion of protocol (above wavy line) used to assess continuous-type gas and oil accumulations. The computational model is described in a separate section.

threshold can be met. The computational model (described in the following section) incorporates the play probability as a weighting factor in calculating unconditional play potential.

The possibility exists that a play is so speculative that an effort at quantitative assessment could not be defended. For such cases, we have adopted the convention that a continuous-type play will not be assessed if the play probability is less than 0.11 .

After assigning risk to a play, the assessment process can be regarded as proceeding along two parallel flow paths. The right branch of Figure 10 addresses the number of productive, untested cells in a play, and the left branch addresses the production expected from those cells.

\section{Estimate Number of Untested Cells in Play}

Forpurposes of resource assessment, it is convenient to envision the hydrocarbons of a continuous-type accumulation as residing in cells. A play is then regarded as a collection of cells of area or size equal to the typical spacing expected for wells of the play (Fig. 11). The total number of cells in a play equals the area of the play $\left(\mathrm{mi}^{2}\right)$ divided by the cell size $\left(\mathrm{mi}^{2}\right)$.

A cell is characterized as either evaluated or untested (Fig. 11). An evaluated cell is either productive or nonproductive. The number of untested cells in a play equals the total number of cells minus the productive and nonproductive cells.

Uncertainties in defining play boundaries, in the number of evaluated cells, and in the cell size lead to measurement error in the number of untested cells. This measurement error is expressed by estimating the minimum possible number and maximum possible number of untested cells in the play(see notes in Appendix A). For cases where measurement error in the number of untested cells is significant, provision is made in the computational model to treat the number of untested cells as a probability distribution.

\section{Estimate Success Ratio for Untested Cells of Play}

One approach to estimating success ratio is to extrapolate results of existing drilling in a play to the untested cells of the same play. Success ratio is then the number of productive cells divided by the number of cells evaluated (productive plus nonproductive).

If existing drilling results are not typical of the play as a whole, or the play is insufficiently drilled to establish a realistic success ratio, or the play has no productive cells (a hypothetical play), success ratio 


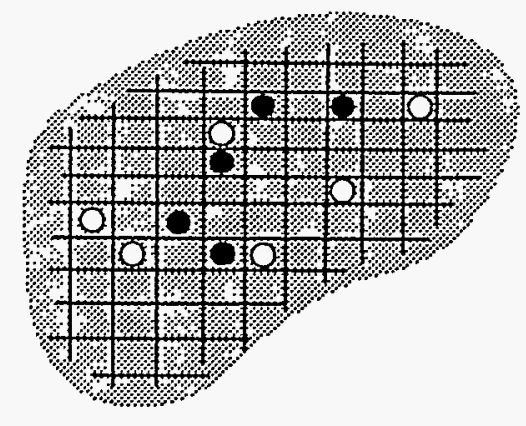

Figure 11. Sketch depicting a continuous-type play as a collection of cells of area equal to typical spacing expected for wells of the play. Circles represent cells that have been evaluated by wells; evaluated cells are either productive (solid circles) or nonproductive (open circles). Remaining cells are untested.

can be based upon drilling results from an analog play or upon concepts regarding geologic factors controlling production.

Success ratio is treated in the computational model as a single-valued parameter. As shown schematically in Figure 10 the combination of success ratio and number of untested cells yields the number of productive, untested cells expected for a play. However, the computational model provides no insight as to which untested cells are expected to be productive.

\section{Establish Estimated Ultimate Recovery (EUR) Probability Distribution for Productive, Untested Cells of Play}

The initial step in generating this EUR probability distribution is to selectagroup of wells that form a sample set representative of the productive, untested cells of the play. Wells from an analog play can be used if necessary.

The next step is to calculate EUR values for these wells (see section on acquisition and analysis of production data). Because the EUR probability distribution provides a reference model for productive, untested cells of the play, production data that are thought to be atypical of the productive, untested cells are not used. The assumption that the EUR probability distribution replicates future production from productive, untested cells is unlikely to be valid if the EUR values display a pronounced time or spatial dependence.
If a fully developed EUR probability distribution analogous to Figure 12 carı be generated, seven fractiles (the 100th, 95th, 75th, 50th, 25th, 5th, and 0th probabilities) are supplied to the computational model. The 100th, 50th, and 0th fractiles represent the minimum, median, and maxirnum EUR's of the distribution, respectively. In cases of poorer data, where details of the EUR probability distribution are uncertain, three fractiles (the 100th, 50th, and 0th probabilities) are supplied to the computational model and a log-normal probability distribution is assumed. In most cases, the minimum EUR is taken as zero, which is the value for which there is absolute certainty that a productive cell's EUR will be higher. In most cases, the EUR profile is drawn to a point of trunction that is equal to the maximum anticipated EUR at the Oth fractile.

At this point in the assessment procedure, the fundamental geologically based elements of the assessment are established. The computational model calculates the base-case assessment (Fig. 10) by combining the play probability, number of untested cells, success ratio, and EUR probability distribution.

\section{Ancillary Data for Play}

In order to assess co-products in a play (gas in an oil play or oil and condensate in a gas play) and to provide background data for a play, selected ancillary data are assembled. These: data are: 1) the ratio of total gas to oil (cubic feet of gas per barrel of oil) for an oil play, or the ratio of oil and natural-gas liquids to total gas (barrels of liquid per million cubic feet of gas) for a gas play; 2) the minimum, maximum, and median depths ( $\mathrm{ft}$ ) of untested cells; 3 ) the fraction (0-1.0) of untested cells expected to be evaluated by wells originally targeted for the play, for a deeper horizon, and for a shallower horizon; 4) the: API gravity (degrees) of oil and condensate in the play; 5) the fraction (0-1.0) of the play that carries a "tight" Federal Energy Regulatory Commission (FERC) designation; and 6) the fraction $(0-1.0)$ of the play that may be off-limits to drilling in the foreseeable future for reasons such as wilderness or park designations, environmental restrictions, Native American concerns, physical inaccessibility, etc.

\section{OPERATIONAL ASPECTS}

The information and attributes required for the assessment of continuous-type accumulations are supplied by earth scientists who are experts regarding the area under consideration. These regional experts 


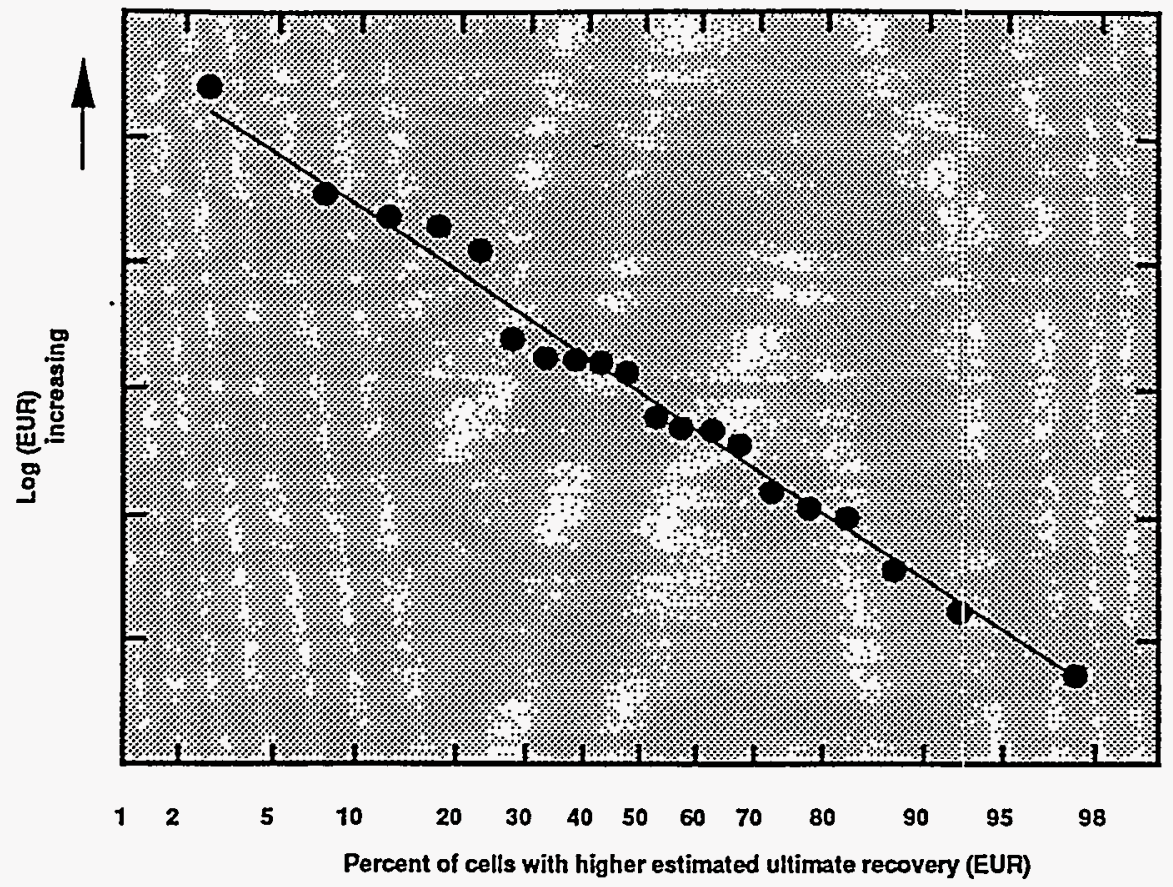

Figure 12. Illustration using hypothetical data of estimated ultimate recovery (EUR) probability distribution for productive, untested cells of a continuous-type play. Horizontal axis is that of arithmetic probability paper.

complete a form for each play, which is the source of the input data required for the computational model and also provides selected ancillary information. Completed data forms are included in this report in Appendix A.

To bridge the gap between the data form and the expanded explanation of the assessment model presented here, and to promote procedural uniformity among plays, a succinct outline (Appendix B) that provides guidelines for completing the data form is supplied to each regional expert.

In overview, experienced earth scientists supply the data required by the assessment model, and computer routines programmed to implement the assessment model execute the resource calculations. This arrangement combines the expertise of geologists, geophysicists, and petroleum engineers with the computer's facility for manipulation of numbers.

\section{Remarks}

A comprehensive assessment of the nonassociated gas resources of the Uinta Basin must consider unconventional hydrocarbon accumulations. To this end, we identify a category of unconventional accumulation that we call a continuous-type accumulation, and describe a model for assessing potential reserve additions from this type of oil or gas accumulation.

Our assessment model relies on existing production to characterize reserve additions expected from undrilled portions of continuous-type plays. The paradigm that in-place hydrocarbon volume is the foundation for unconventional-resource assessment is not endorsed. A consequence of using production histories from existing wells is that we do not rely upon projections of secondary parameters such as porosity, permeability, water saturation, and net pay. The integrated effect of all these factors is reflected in a well's production data.

Our assessment model projects past and present production patterns into the future. Therefore, the "base-case" assessment (Fig. 10) implicitly incorporates a continuation of historical technologic and economic trends. Although beyond the scope of the present work, it would be possible to modify the basecase assessment to reflect perceptions of future economic and technologic change.

\section{PROBABILISTIC METHODOLOGY FOR ASSESSMENT OF IPETROLEUM RESOURCES FROM CONTINUOUS-TYPE ACCUMULATIONS}

\section{Introduction}

A geostochastic system called UNCLE (unconventional energy) was developed for the assessment of oil and gas resources from continuoustype accumulations. UNCLE is an efficient appraisal 
system for petroleum play analysis that uses a geologic probability model and an analytic probabilistic methodology.

In play analysis, geologic plays are defined within a petroleum assessment area, and the individual plays are analyzed. The individual play estimates of oil and gas are aggregated, respectively, to estimate the petroleum potential of the entire assessment area. Therefore, UNCLE is comprised of two separate probabilistic methodologies: one for play analysis and another for play aggregation.

The geologic model for a play consisting of a continuous-type accumulation is basically a numbersize model in which the number and sizes of volumes of oil and gas from a continuous-type accumulation are modeled (Fouch et al., 1994).

The probabilistic methodologies that were developed to solve the play analysis model and the play aggregation problem are analytic methodologies derived from probability theory as opposed to Monte Carlo simulation. Resource estimates of undiscovered, recoverable unconventional oil and gas resources are calculated and expressed in terms of probability distributions.

There are many steps necessary to be able to go from the geologic probability model to the resource estimates. The complete quantitative procedure requires the following steps:

1. The geologic probability model defines an extremely complex probability problem.

2. The probability problem is essentially characterized by a data form.

3. The data form is solved by developing a probabilistic methodology.

4. The probabilistic methodology is based on analytic probability theory.

5. The analytic probability theory is used to derive numerous mathematical equations.

6. The mathematical equations are the basis for designing computer algorithms.

7. The computer algorithms are needed to write large, complicated computer programs.

8. The computer programs are run to perform the data processing.

9. The data processing results in the generation of the resource estimates.

10. The resource estimates are produced in the form of tables or graphs.

\section{GEOLOGIC PROBABILITY MODEL}

A geologic model for the quantity of undiscovered petroleum resources in a play involves uncertainty because of the incomplete or fragmentary geologic information generally available. The geologic probability model defines an extremely complex probability problem. The basic information required by the geologic probability model is put on a data form. The data form is filled out by the geologist who is assessing the play.

The geologic probability model consists of the following geologic and probabilistic descriptions and assumptions:

1. The play type is oil or gas.

2. The play probability is the probability thatuntested cells of a play are capable of producing at least a specified minimum quantity of resources, i.e., the play is favorable.

3. The number of untested cells in the play is"a discrete random variable that is characterized by three estimated values: median value, minimum value, and maximum value, which are also the fractiles $F 50, F 100$, and F0, respectively, where, for example, $F_{50}$ denotes the value where the probability of exceeding it is 0.50 . Four more fractiles $F_{95}, F_{75}, F_{25}$, and $F_{5}$ are calculated assuming a constructed probability distribution that is bell-shaped symmetric if $F_{s 0}$ is equal to the midpoint of $F_{100}$ and $F_{0}$, positively skewed if $F_{50}$ is to the left of the midpoint, and negatively skewed if $F_{50}$ is to the right of the midpoint.

4. The success ratio is the proportion of untested cells expected to be productive.

5. The estimated ultimate recovery (EUR) well size represents the production from productive untested cells. The EUR is a continuous random variable that is characterized by three estimated values: median value $\left(\mathrm{F}_{50}\right)$, minimum value $\left(F_{100}\right)$, and maximum value $\left(F_{0}\right)$; or by seven estimated fractiles: $F_{100}, F_{95}, F_{75}, F_{50}, F_{25}, F_{5}$, and $F_{0}$. In the case of only three given fractiles, the four remaining fracliles are calculated assuming a lognormal distribution.

6. If an oil piay, the expected ratio of total gas to oil (GOR) is estimated.

7. If a gas play, the expected ratio of oil and natural gas liquids to total gas is estimated. 
8. The depth of the untested cells is a continuous random variable that is characterized by three estimated values: median value, minimum value, and maximum value. The depth is not used in any of the calculations.

9. A subplay model is an option to estimate resources in a fraction of the play from estimates of the entire play.

10. An available economic model truncates distributions of the EUR using a minimum economic cut-off value.

Probability judgments concerning the play parameters and random variables are made by experts familiar with the geology of the area of interest. The experts review all available data relevant to the appraisal, identify the major plays within the assessment area (e.g., basin or province), and then assess each identified play. All of the geologic data required by this model for a play are entered on an oil and gas appraisal data form. Information from the data form is entered into computer data files as the input for a computer program based upon an analytic method.

\section{PROBABILISTIC METHODOLOGY}

\section{Play Analysis-UNCLE}

The analytic method was developed by the application of many laws of expectation and variance in conditional probability theory. It systematically tracks through the geologic probability model, computes all of the means and variances of the appropriate random variables, and calculates all of the probabilities of occurrence. In arriving at probability fractiles, the lognomal distribution is used as a model for the play resource distribution (Crovelli, 1984). Oil, nonassociated gas, associated-dissolved gas, gas, and liquids in nonassociated gas are possible resources assessed depending upon whether the type of play is oil or gas. A simplified flowchart for the method is presented in Figure $\mathrm{C} 1$.

The basic steps of the analytic method of play analysis (UNCLE) are:

1. Select the play.

2. Select the play type: oil or gas. For illustrative purposes, suppose the play type is oil.

3. Compute the mean and variance of the estimated ultimate recovery (EUR) well size of oil using the estimated seven fractiles and assuming a uniform distribution between fractiles, that is, a piecewise uniform probability density function (as is done in the case of a simulation method).

4. Compute the mean and variance of the number of untested cells from the estimated seven fractiles, assuming a uniform distribution between fractiles (as is also the case in a simulation method).

5. Compute the mean and variance of the number of productive, untested cells by applying the success ratio of oil to the mean and variance of the number of untested cells.

6. Compute the mean and variance of the conditional (A) play potential for oil-the quantity of oil in the play, given the play is favorable. These values are determined from the probability theory of the expectation and variance of a random (number of productive, untested cells) of random variables (estimated ultimate recovery well sizes).

7. Compute the conditional play probability of oilthe probability that a favorable play has at least one productive, untested cell. This probability is a function of the success ratio of oil and the number of untested cells distribution.

8. Compute the mean and variance of the conditional (B) play potential for oil - the quantity of oil in the play, given the play is favorable and there is at least one productive, untested cell within the play. These values are determined by applying the conditional play probability of oil to the mean and variance of the conditional (A) play potential for oil.

9. Compute the unconditional play probability of oil - the probability that the play has at least one productive, untested cell. This probability is the product of the conditional play probability of oil and the play probability.

10. Compute the mean and variance of the unconditional play potential for oil-the quantity of oil in the play. These values are determined by applying the unconditional play probability of oil to the mean and variance of the conditional (B) play potential for oil.

11. Model the probability distribution of the conditional (B) play potential for oil by using the lognormal distribution with mean and variance from step 8. Calculate various lognormal fractiles.

12. Compute various fractiles of the conditional $(A)$ play potential for oil by a transformation to appropriate 


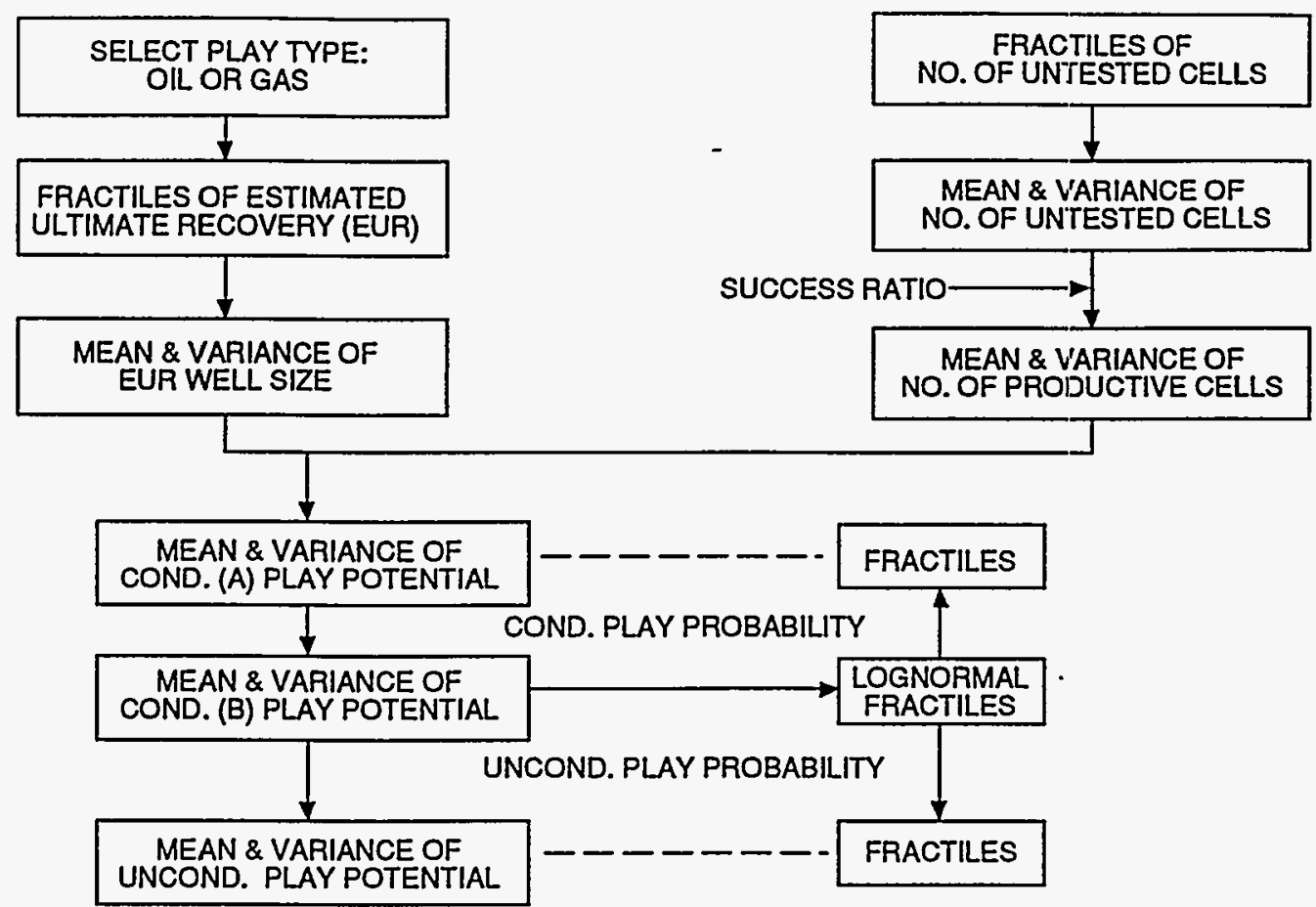

Figure C1. Flowchart for analytic method of play analysis (UNCLE).

lognormal fractiles of the conditional (B) play potential for oil using the conditional play probability of oil.

13. Compute various fractiles of the unconditional play potential for oil by a transformation to appropriate lognormal fractiles of the conditional (B) play potential for oil using the unconditional play probability of oil.

14. Process associated-dissolved gas as a second resource to be assessed. Repeat steps 3 through 13, substituting associated-dissolved gas for oil, with two basic modifications as follows. The estimated ultimate recovery (EUR) well size of oil is multiplied by the gas-oil ratio. The success ratio of associateddissolved gas is the same as the success ratio of oil.

15. Suppose nonassociated gas is the resource to be assessed, i.e., the play type is gas. Repeat steps 3 through 13 ,substituting nonassociated gas foroil and using the estimated ultimate recovery (EUR) well size of nonassociated gas and the success ratio of nonassociated gas.

16. Process liquids in nonassociated gas as a second resource to be assessed. Repeat steps 3 through 13, substituting liquids in nonassociated gas for oil, with two basic modifications as follows. The estimated ultimate recovery (EUR) well size of nonassociated gas is multiplied by the expected ratio of liquids to nonassociated gas. The success ratio of liquids in nonassociated gas is the same as the success ratio of nonassociated gas or zero if the liquids ratio is zero.

\section{Play Aggregation-UNCLE-AG}

A separate probabilistic methodology was developed to estimate the aggregation of a set of plays. The resource estimates of the individual plays from play analysis using the UNCLE program are aggregated using an analytic probability method. Oil, nonassociated gas, associated-dissolved gas, gas, and liquidsinnonassociated gas resources are each aggregated in tum. UNCLE-AG is also able to aggregate a set of plays under adependency assumption. A simplified flowchart of play aggregation is presented in Figure $\mathrm{C} 2$.

The basic steps of the analytic method of play aggregation are:

1. Select plays to aggregate.

2. Process oil as the first resource to be aggregated.

3. Compute the mean, variance and fractiles of the unconditional aggregate potential for oil in the 


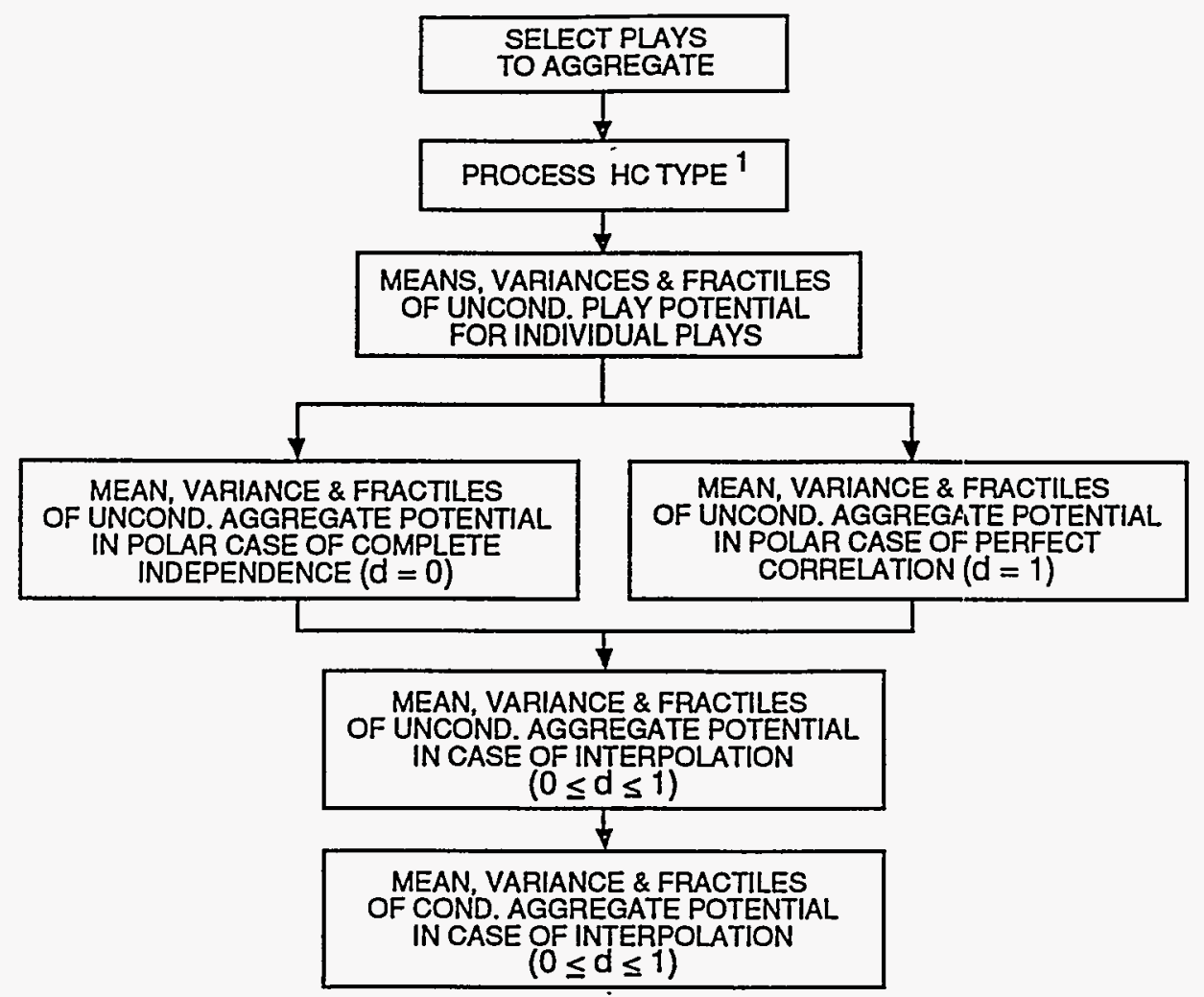

1 OIL, NONASSOCIATED GAS, ASSOCIATED-DISSOLVED GAS, GAS, AND LIQUIDS IN NONASSOCIATED GAS RESOURCES ARE EACH AGGREGATIED IN TURN.

Figure C2. Flowchart for analytic method of play aggregation (UNCLE-AG).

polar case of complete independence-the quantity of oil in the assessment area of the aggregated plays under independence.

(a) Determine the mean and variance by adding all the individual play means and variances of the unconditional play potential for oil, respectively.

(b) Calculate the unconditional aggregate probability of oil-the probability that the assessment area has at least one play with oil - from the individual unconditional play probabilities of oil under the assumption of independence.

(c) Compute the mean and variance of the conditional aggregate potential for oil-the quantity of oil in the assessment area, given the assessment area has at least one play with oil. These are determined by applying the unconditional aggregate probability of oil to the mean and variance of the unconditional aggregate potential for oil.

(d) Model the probability distribution of the conditional aggregate potential for oil by using the lognormal distribution with mean and variance from (c).

(e) Compute various fractiles of the unconditional aggregate potential for oil by a transformation to appropriate lognormal fractiles of the conditional aggregate potential for oil using the unconditional aggregate probability for oil.

4. Compute the mean, variance and fractiles of the unconditional aggregate potential for oil in the polar case of perfect positive correlation-the quantity of oil in the assessment area of the aggregated plays under perfect correlation.

(a) Determine the mean and standard deviation by adding all the individual play means and 
standard deviations of the unconditional play potential for oil, respectively.

(b) Calculate the unconditional aggregate probability of oil-the probability that the assessment area has at least one play with oil-from the individual unconditional play probabilities of oil under the assumption of perfect positive correlation.

(c) Compute various fractiles of the unconditional aggregate potential for oil by adding all the individual play fractiles of the unconditional play potential for oil, respectively.

5. Compute the mean, variance and fractiles of the unconditional aggregate potential foroil in the case of interpolation between the polarcase of complete independence $(d=0)$ and the polar case of perfect positive correlation $(d=1)$ - the quantity of oil in the assessment area of the aggregated plays under a degree of dependency, $d(0 \leq d \leq 1)$. Interpolate the mean, standard deviation, fractiles, and unconditional aggregate probability of oil between the two polar cases of steps 3 and 4.

6. Compute the mean, variance and fractiles of the conditional aggregate potential for oil in the case of interpolation-the quantity of oil in the assessment area, given the assessment area has at least one play with oil.

(a) Determine the mean and variance of the conditional aggregate potential foroil by applying the interpolated unconditional aggregateprobability of oil to the interpolated mean and variance of the unconditional aggregate potential for oil.

(b) Model the probability distribution of the conditional aggregate potential for oil by using the lognomal distribution with mean and variance from (a). Calculate various lognormal fractiles.

7. Process nonassociated gas as the second resource to be aggregated. Repeat steps 3 through 6 using play-analysis estimates of nonassociated gasnamely, the individual play means, variances and fractiles of the unconditional play potential for nonassociated gas, as well as the individual unconditional play probabilities of nonassociated gas.

8. Process associated-dissolved gas as the third resource to be aggregated. Repeatsteps 3 through 6 using play-analysis estimates of associated- dissolved gas-namely, the individual play means, variances and fractiles of the unconditional play potential for associated-dissolved gas, as well as the individual unconditional play probabilities of associated-dissolved gas.

9. Process gas as the fourth resource to be aggregated. Repeat steps 3 through 6 using play-analysis estimates of gas - namely, the individual play means, variances and fractiles of the unconditional play potential for gas, as well as the individual unconditional play probabilities of gas.

10. Process liquids in nonassociated gas as the fifth resource to be aggregated. Repeat steps 3 through 6 using play-analysis estimates of liquids in nonassociated gas-namely, the individual play means, variances and fractiles of the unconditional play potential for liquids in nonassociated gas, as well as the individual unconditional play probabilities of liquids in nonassociated gas.

\section{Relationship Between UNCLE and UNCLE-AG}

UNCLE-AG is related to UNCLE as follows. UNCLE not only generates a file of resource estimates for an individual play but also outputs a second file of results that consists of the inconditional play probability, cutoff, mean, standard deviation and fractiles of the unconditional play potential for each of the seven resources. The second file is needed for an aggregation of plays and forms an input file for UNCLE-AG. Therefore, after UNCLE is nun on each play in a set of plays, any subset of plays can be aggregated by running UNCLE-AG on the corresponding subset of aggregation input files. UNCLE-AG not only generates a file of resource estimates for an aggregation of plays but also outputs a second file of results needed for an aggregation of aggregations, which forms yet another input file for UNCLE-AG. Hence, after UNCLE-AG is run on each aggregation in a set of aggregations, any subset of aggregations can be aggregated at once. Compared to the simulation method, the application of UNCLE-AG can result in tremendous savings of time and cost, especially when analyzing many aggregations involving hundreds of plays.

\section{ACQUISITION AND ANALYSIS OF PRODUCTION DATA}

Data for the calculation of estimated ultimate recovery (EUR) for wells within a specified play are obtained 
from the Petroleum Information Corporation data base, or from other publically available data. Due to the absence of reservoir pressure data and reservoir fluid pressure-volume-temperature (PVT) analyses, plots of pressure versus cumulative gas produced ( $\mathrm{PZ}$ plots) for gas reservoir EUR determination cannot be generated. Therefore, an estimate of the ultimate recovery relies upon the production history and a decline curve analysis (DCA).

The wells selected to generate the EUR distribution must represent the range of productivities within the area. Production histories of insufficient duration (less than 30 months) or inconsistent behavior are excluded from the analysis due to the increased uncertainty imposed by the DCA approach. Inactive wells are included because these types of wells will be encountered in the drilling of the untested cells. A history of downtime was generally not included in forecasting the future productivity of the well.

This use of DCA assumes, in part, that there are no backpressure effects, gas flow into the wellbore is radial, the wells are producing in a stage of depletion and that the cumulative effects that have altered production in the past will continue to do so in the future. Segmented exponential declines are used to represent historical and forecasted production. A maximum producing life of 35 years or an economic limit of 10 MCFD is imposed. If the production rate is high at the end of the 35 year limit, a constant decline rate during the last five years of production forces productivity to the economic limit of $10 \mathrm{MCFD}$. Figure 13 is an illustration of the use of DCA for a Wasatch producer located in T $10 \mathrm{~S}$ and R $19 \mathrm{E}$ of the Uinta Basin, Utah.

The calculated EUR's for the specified play are arranged in descending order and are plotted on semilog probability paper (Fig. 14). This represents the EUR distribution of the untested cells of the play. In some cases we present two or more EUR profiles for a play that are based upon production from within the limits of the play or from plays selected as geologic analogues. Where more than EUR distribuation is available, we select that profile we believe most representative of the play in general (see EUR distributions in Appendix A).

\section{GEOLOGIC FRAMEWORK}

Most reservoirs are within lenticular fluvial sandstones that occur within two major sedimentary systems. Figure 15 illustrates these two systems in a chronostratigraphic cross section that extends from exposures in central Utah to those along the Book and
Roan Cliffs that mark the southem edge of the Uinta Basin. Figure 16 illustrates many of these same strata between Price Canyon and the Natural Buttes gas field. In the first sedimentary system, Upper Cretaceous impermeable fluvial rock reservoirs occur within the Blackhawk, Castlegate, Sego, Neslen, Farrer, Tuscher, and Price River Formations which are assigned to the Mesaverde Group. A second sedimentary system consists of Tertiary rocks that occur in the Maastrichtian to lower Eocene North Hom Formation, and in the Paleocene and Eocene Wasatch and Colton Formations. Locally, fluvial sandstones of the Eocene part of the Green River Formation are tight-gas reservoirs but many operators frequently group the fluvial Green River reservoirs with those of the Wasatch Formation when applying stratigraphic terminology.

\section{Upper Cretaceous Mesaverde Group and Associated Rocks}

Paleogeographic maps and cross sections characterize and portray the primary sedimentologic and stratigraphic composition of the basin's hydrocarbon-bearing strata. Figures 17, 18, 19, and 20 are paleogeographic maps that correspond to periods of Late Cretaceous time. The figures collectively indicate the stratigraphic and sedimentologic composition of Mesaverde rocks in the basin. The maps also display stratigraphic names frequently applied to these rocks. Mesaverde gas is being produced from these rocks but the system remains largely untested. Penetrations of the Mesaverde Group in regions other than at the margins of the basin are few. In addition, most Mesaverde tests lie east of the Green River. Successful completions in Cretaceous rocks are few and data sufficient for analysis of Cretaceous units are likewise sparse. Some operators are attempting to complete in Upper Cretaceous Mesaverde gas-bearing rocks where they underlie the productive Tertiary units and where gas from earh formation can be commingled. However, in general, most gas encountered in Uinta Basin tight sandstone of Cretaceous age has been in rocks deposited in braidplain and coastal-plain settings. A later discussion in this paper indicates that coastal plain units that contain abundant woody organic matter are a major source of gas in the basin.

\section{Paleocene and Eocene Wasatch Formation and Associated Rocks}

Marginal-lacustrine channel sandstones comprise the principal reservoirs for oil and gas in Tertiary 


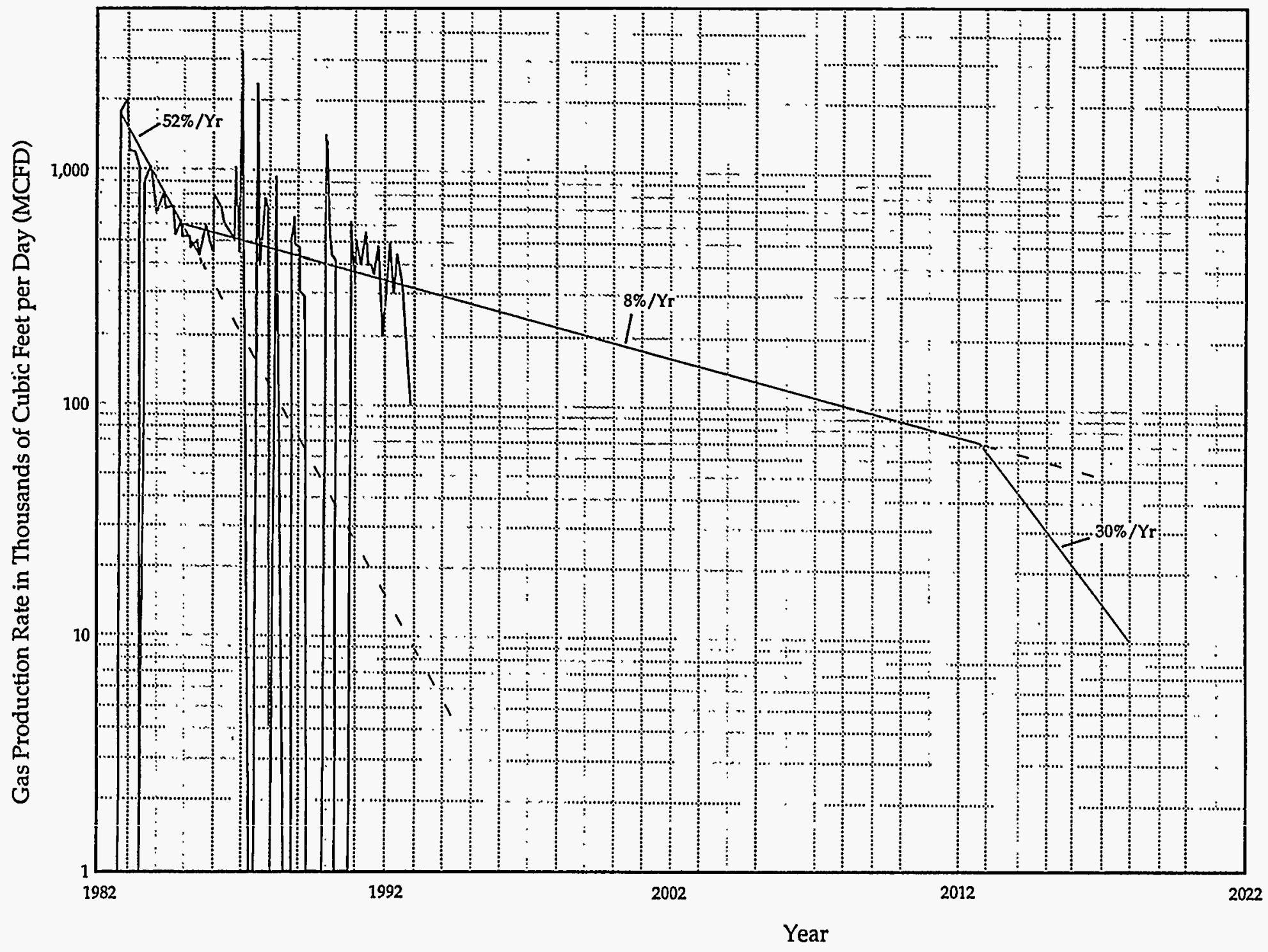

Figure 13. Production rate curve (thousands of cubic feet per day versus year) for a Wasatch producer located in the Uinta Basin, Utah. The straight solid lines show the exponential segments of the decline curve analysis (DCA) of the well. The area under the solid lines is the estimated ultimate recovery (EUR). The dashed lines are extrapolations of straight line segments of the initial and succeeding decline rates. To impose a 35 year well life, a constant decline rate is forecasted in year 30 to force the productivity to an economic limit of 10 MCFD in year 35. 


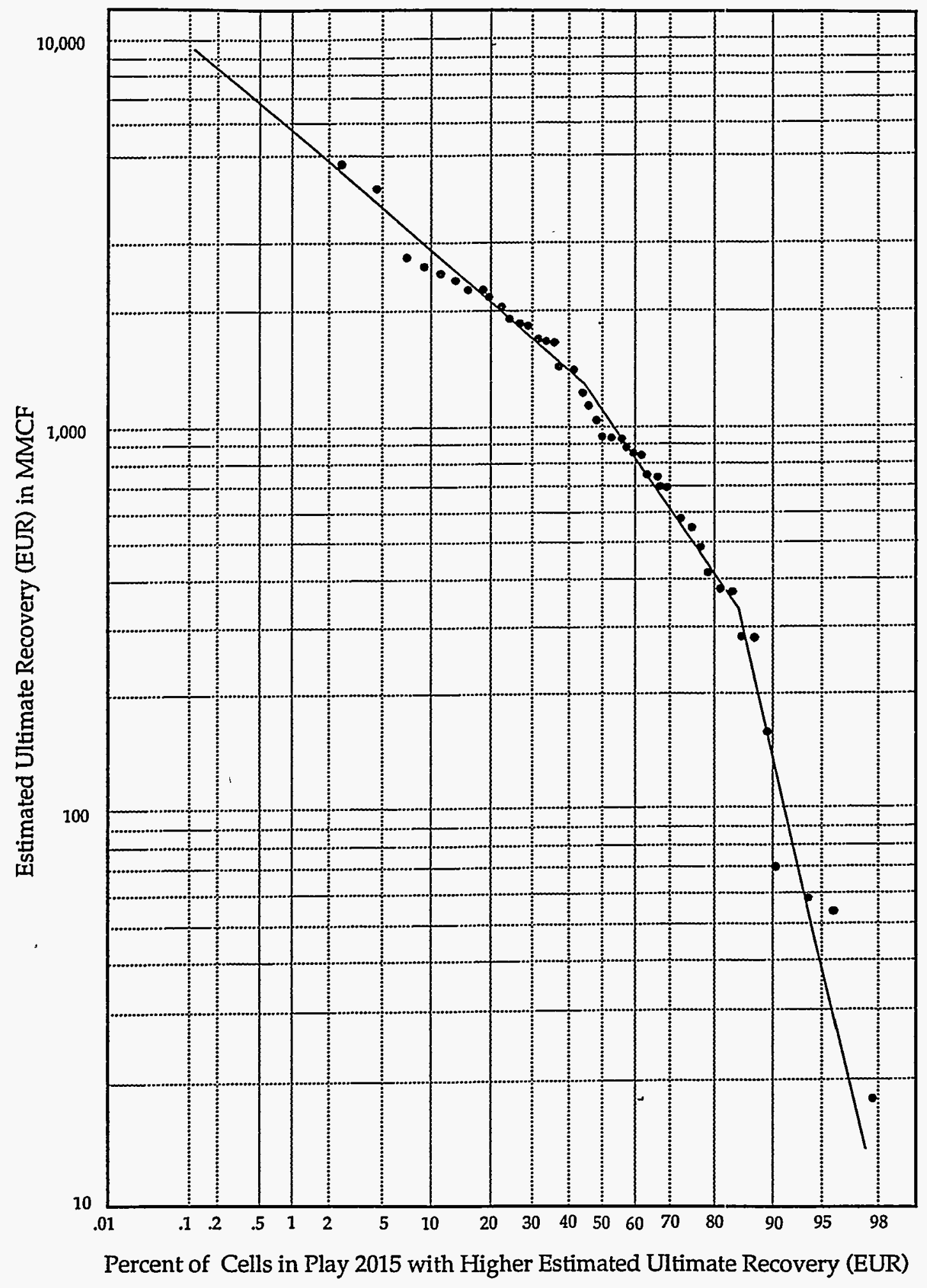

Figure 14. Estimated ultimate recovery (EUR) distribution of a 45 well sample set representing the untested cells in a Wasatch, Uinta Basin play. The log of the EUR in millions of cubic feet is plotted against an arithmetic probability scale. The EUR calculated for the well in figure 13 represents one point on this distribution. 


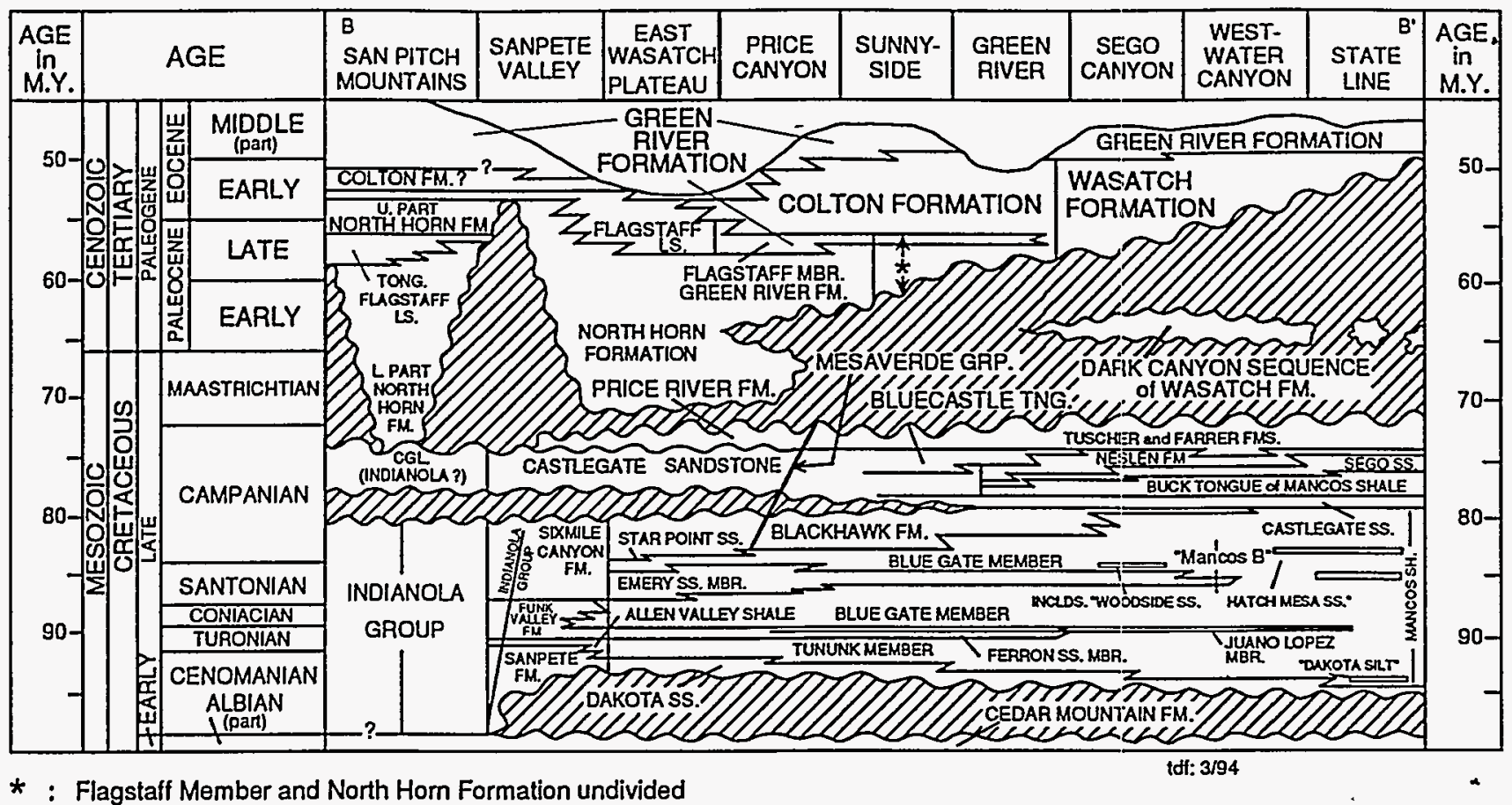

Figure 15. Albian to middle Eocene chronostratigraphic diagram along cross section line illustrating nomenclature and temporal relations of major strata from the Sanpete Valley of central Utah to the Book Cliffs of eastern Utah via the southern part of the Uinta Basin, Utah (modified from Fouch and others, 1983, and Franczyk and others, 1989; Fouch and others,1992). Vertical line through strata indicates a change in stratigraphic nomenclature. Quote marks indicates an informal name applied locally to stratigraphic unit.

strata, and alluvial channel sandstones are the basin's principal Tertiary (and Cretaceous) reservoirs for nonassociated gas.

The cyclic nature of the Tertiary units and the interbedding of mixed lake and alluvial rocks (Green River Formation) with red colored alluvial strata (Wasatch, Colton, and North Hom Formations) has resulted in some confusion in the application of stratigraphic names. Most formational names applied in the basin are representative of lithologic and depositional facies. As a result, several facies and formations can be preserved within a thin stratigraphic interval.

Figure 21,22, 23, 24, and 25 illustrate the paleogeographic distribution of depositional facies for three periods of geologic time in the Paleogene. The maps also display stratigraphic names frequently applied to these rocks. The sections and maps characterize units within $100 \mathrm{ft}$ of strata approximated by the Paleocene lower marker of the Flagstaff Member of the Green River Formation, the Paleocene-Eocene boundary, and the middle Eocene middle marker of the Green River Formation.

Lower marker rocks are the oldest Tertiary units in the basin that have yielded large volumes of oil or gas.
Both are produced from the region of the AltamontBluebell producing area along the north margin of the formerlake. In the southeastpart of the Uinta, beds of this age onlap Cretaceous units along the northwest margin of the Uncomphagre structural element thus their limits and potential as gas reservoirs do not extend far east of the Green River (Fouch and Cashion, 1979; Stone, 1977). However, several fields (Flat Rock, Agency Draw, Seep Ridge) in the southwest quadrant of the basin yield high pourpoint oil from the southeast extension of lower marker or adjacent rocks.

Oil and associated gas have been recovered from marginal-lacustrine rocks adjacent to the PaleoceneEocene boundary. Like those of the lower marker, the distribution of potential reservoirs and beds of this age are limited where they pinchout against the Uncomphagre structural elementashort distancesoutheast of thepresentday course of the Green River.

Middle marker reservoirs yield large volumes of oil and gas at the extreme east end of the basin in Utah in the region of the Red Wash producing complex. In addition, strata of themiddlemarkerzone and within a fewhundred feet of it yield gas derived from the maturation of organic matter that accumulated in open-lake sites. 

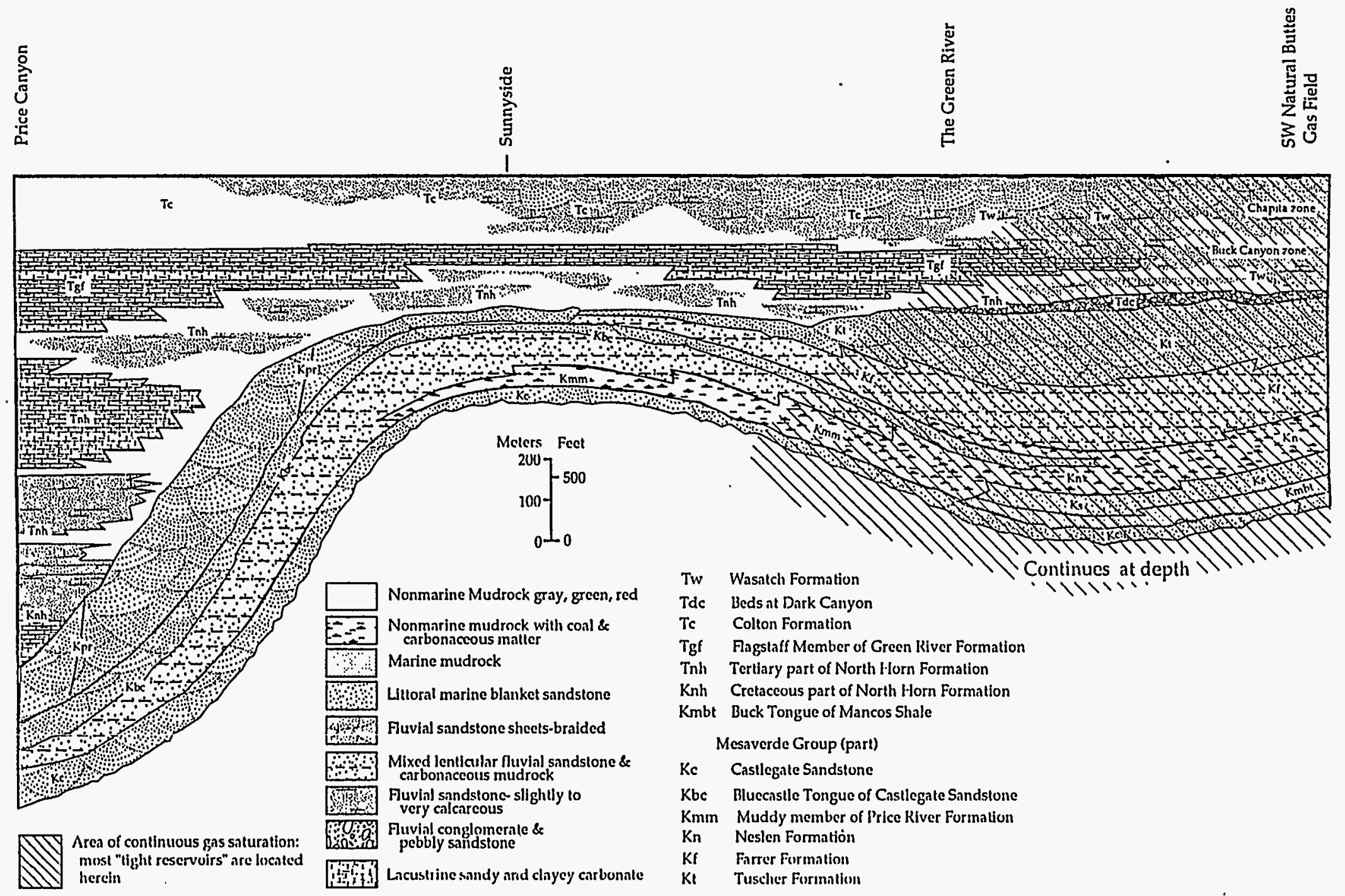

Figure 16. Stratigraphic cross section of upper Campanian through lowest Eocene rocks extending from Price Canyon to Natural Buttes area showing lithofacies and interpreted depositional environments (from Fouch and others, 1983). Rocks displayed on the right half of this section are the gas-bearing units in the eastern part of the Uinta Basin and the lithologic section is similar in composition to that penetwated in the gas fields of the eastern and central part uf the basin. The gas-bearing lower Campanian Blackhawk Formation underlies the Castlegate Sandstone over much of the region but is not shown on the diagram. Tertiary rocks of the left half of the diagram are similar to part of the oil-bearing section in the Altamont-Bluebell area of the north-central Uinta Basin. 


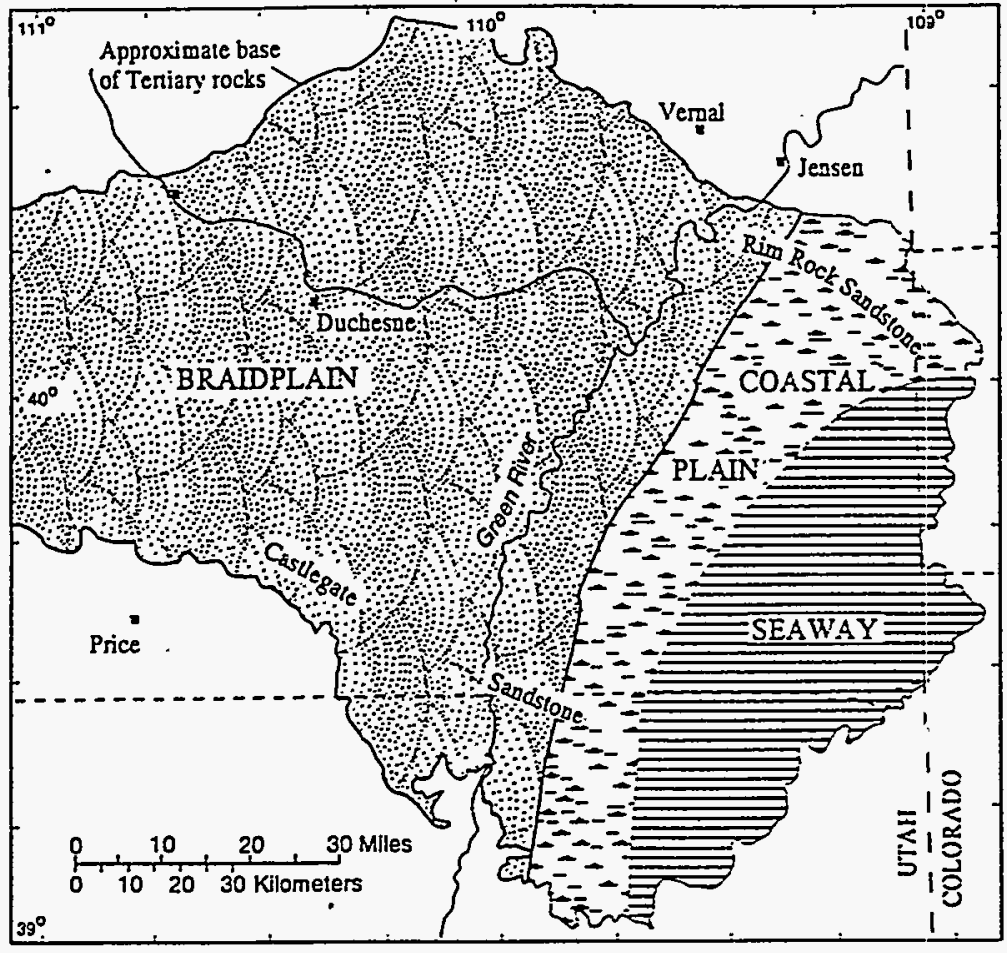

Figure 17. Paleogeographic map including Mesaverde Group depositional-facies at the time of the Campanian marine fossil zone of Baculites asperiformis and its nonmarine extensions (modified from Fouch and others, 1983).

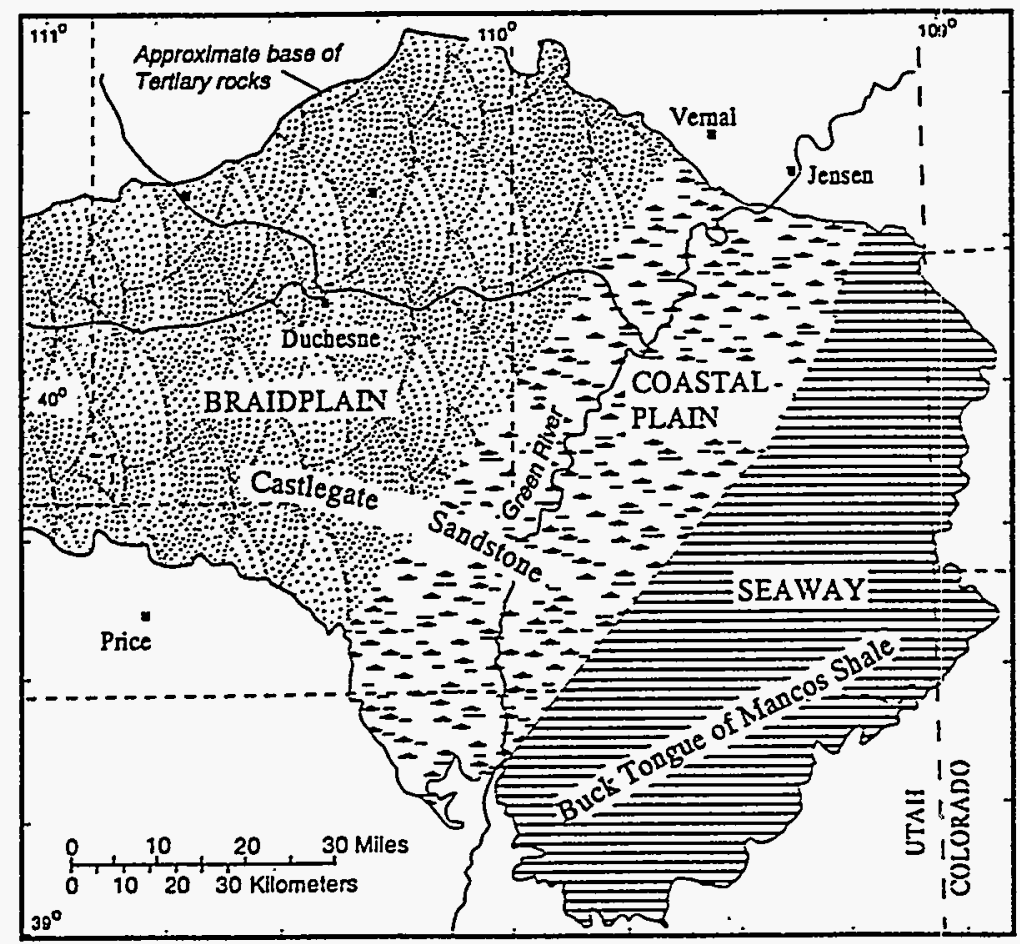

- Figure 18. Paleogeographic map including Mesaverde Group depositional-facies map at the time of the Campanian marine fossil zone of Baculites perplexus and its nonmarine extensions (modified from Fouch and others, 1983). Coastal-plain rocks east of the Green River have yielded numerous gas shows in subsuriace tests and organic matter within them is thought to be a major source of gas in the region. 


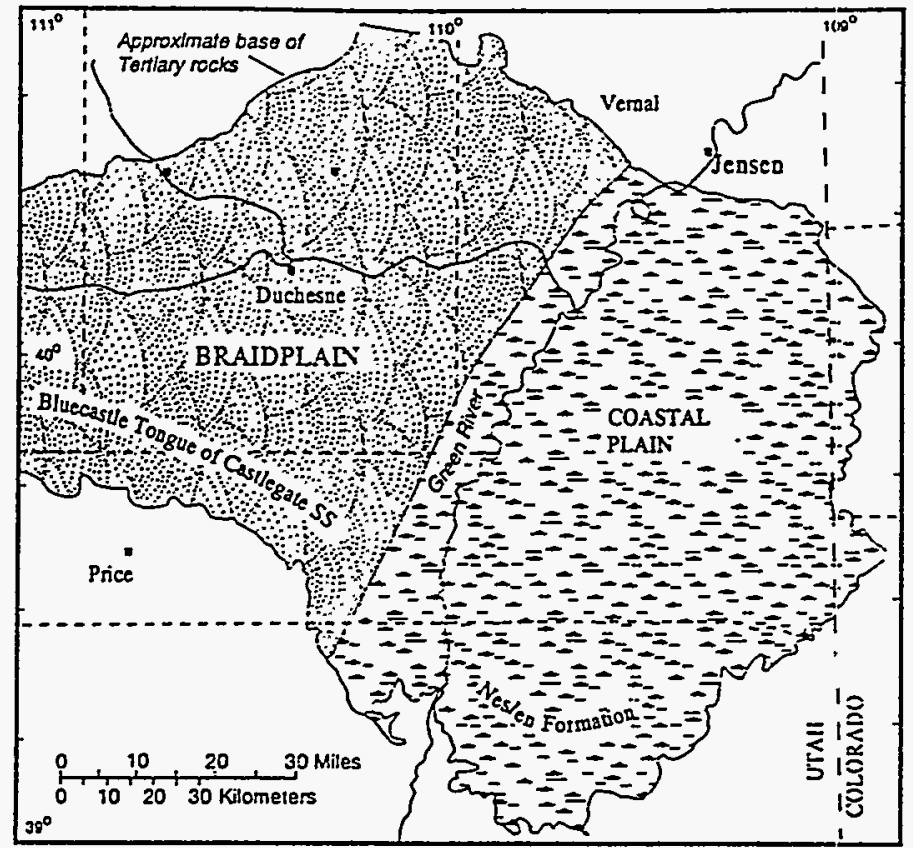

Figure 19. Paleogeographic map including Mesaverde Group depositional-facies at the time of the Campanian marine fossil zone of Didymoceras nebrascense and its nonmarine extensions (modified from Fouch and others, 1983). Coastal-plain rocks east of the Green River have yielded numerous gas showrs in subsurface tests and organic matter within them is thought to be a major source of gas in the region. Rocks of the braidplain facies have yielded gas shows in tests along the southern margin of the basin.

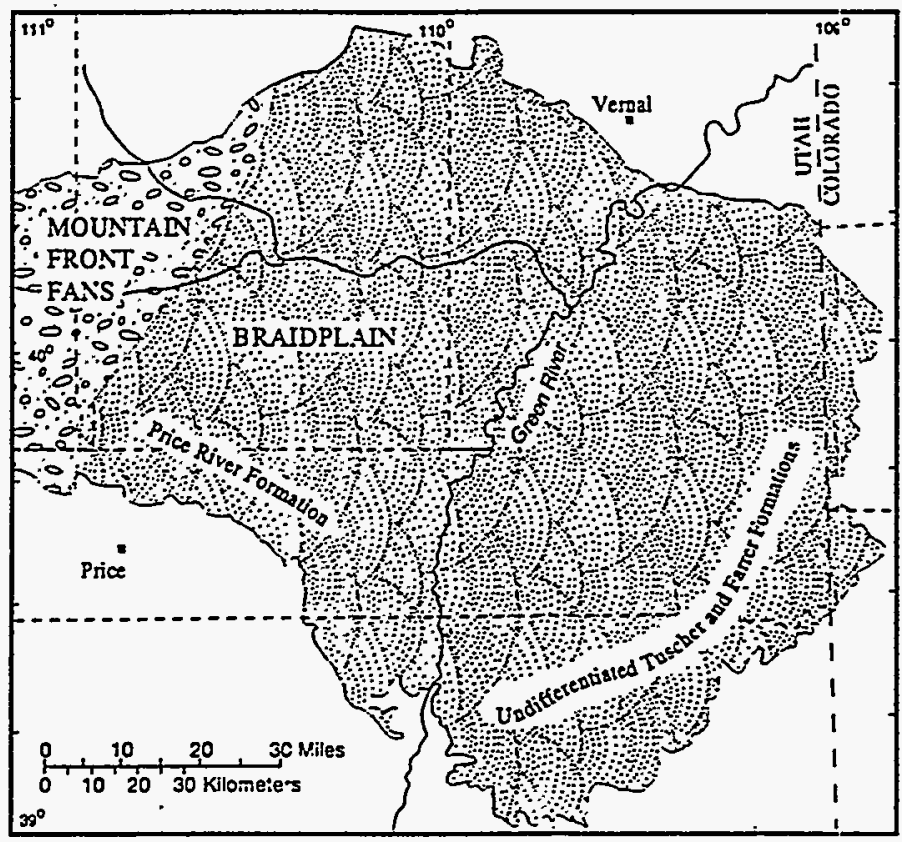

Figure 20. Paleogeographic map including Mesaverde Group depositional-facies at the time of the Campanian marine fossil zone of Baculites cuneatus and its nonmarine extensions (modified from Fouch and others, 1983). Rocks of the braidplain facies have yielded gas shows in tests along the southern margin of the basin and east of the Green River. Much of this zone has been eroded from the top of the Mesaverde in part of the Uinta Basin. Less than $300 \mathrm{ft}$ of younger Campanian and Maastrichtian rocks of the undifferentiated Price River, Tuscher and North Horn (Upper Cretaceous part) is preserved in some areas. 


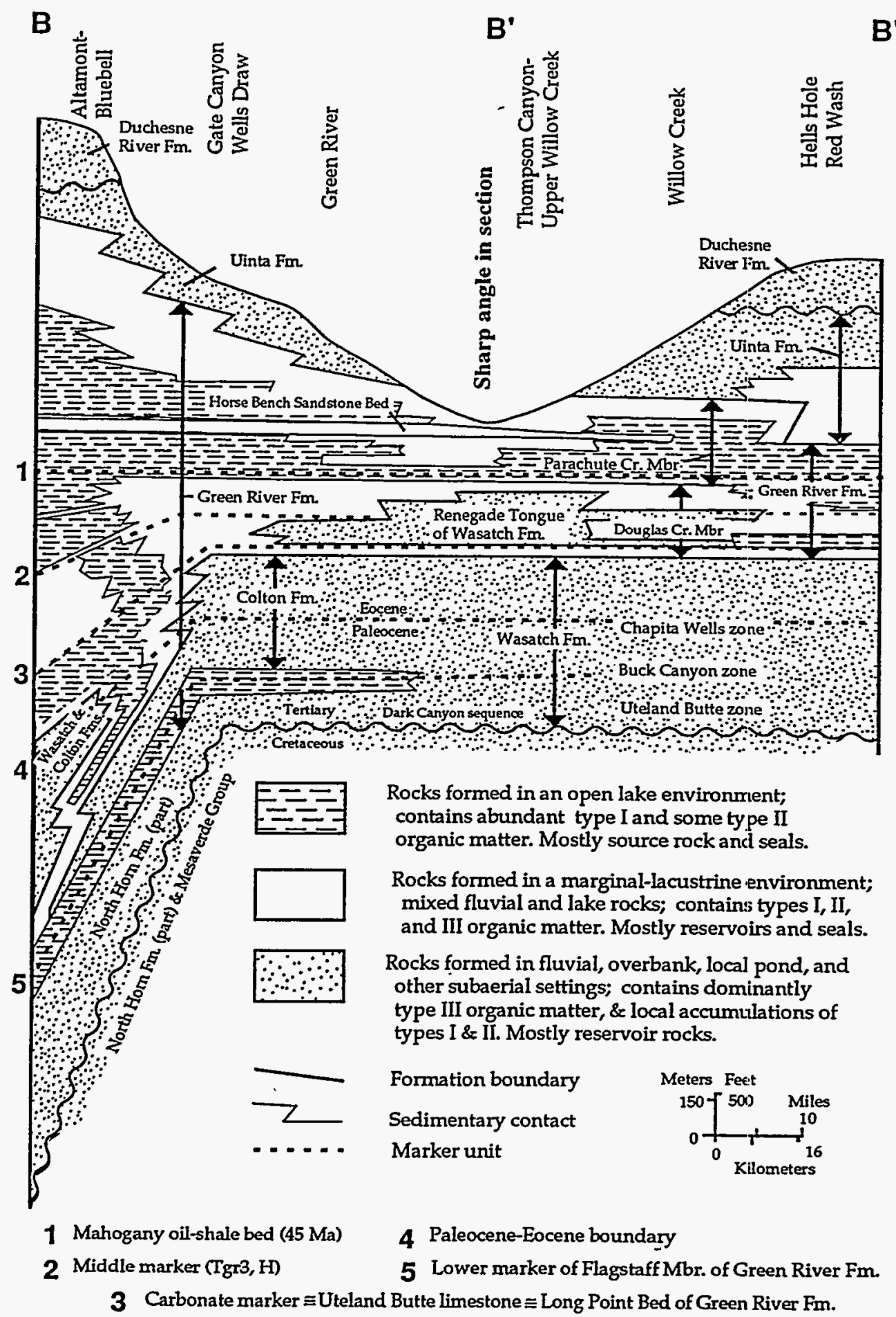

Figure 21. Stratigraphic diagram B-B' that extends east from the Altamont-Bluebell oil field to the Red Wash and Hells Hole areas of the east end of the basin by way of Gate Canyon and Thompson Canyon of the basin's south flank. The Chapita Wells, Buck Canyon, and Uteland Butte zones are local names for gas-producing intervals in the Wasatch Formation of the central and eastern part of the basin. The Uteland Butte limestone is a local name for units that approximate the lower marker of the Green River Formation. Tgr3 is the Shell Oil Company name for the middle marker of the Green River Formation; $H$ is the name for the middle marker commonly used by the Chevron Oil and other companies that operate in the eastern part of the basin. The Dark Canyon sequence is the siliceous pebble conglomerate at Dark Canyon of Fouch and Cashion (1979), and the Dark Canyon sequence of the Wasatch Formation of Franczyk et al (1992). 


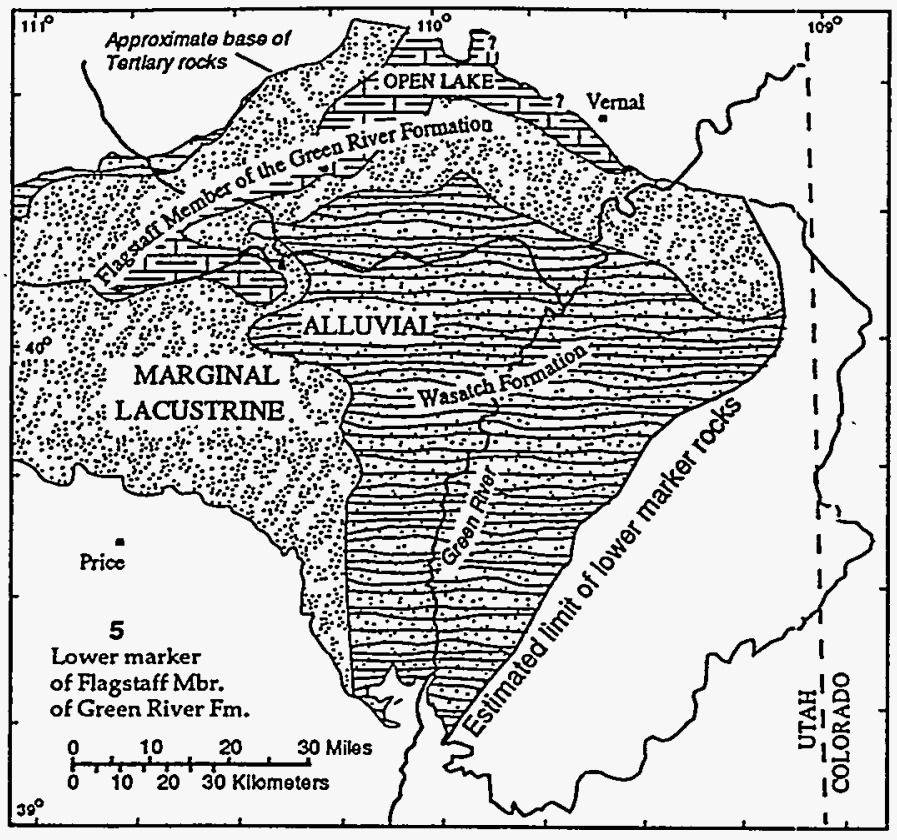

Figure 22. Paleogeographic map including depositional-facies of a zone consisting of beds adjacent and laterally equivalent to the lower marker of the Paleocene and Eocene Flagstaff Member of the Green River Formation (modified from Fouch, 1975, and Fouch, Nuccio et al, 1992). Oil and gas are produced from the Altamont-Bluebell area along the north margin of the lake. In the southeast part of the Uinta Basin, beds of this age onlap Cretaceous units along the northwest margin of the Uncompahgre uplift thus limiting their potential as gas reservoirs east of the Green River (Fouch and Cashion, 1979; Stone, 1977).

Marginal-lacustrine units within this sequence contain gas in much of the eastern and northem parts of the basin. Beds from this stratigraphic sequence also contain tight alluvial sandstone reservoirs of the Wasatch and Colton Formations in the greater Natural Buttes producing area. In this region, the gas is believed to have been derived from woody plant material in the underlying carbonaceous beds of the Mesaverde Group.

\section{THERMAL HISTORY OF ORGANIC MATTER}

\section{Rm Map at Base of the Mesaverde Group.}

Figure 26 is an $\mathrm{R}_{\mathrm{m}}$ map at the base of the Mesaverde Group. The map shows a general trend of increasing maturity from south to north. This trend generally follows the structural configuration on the base of the Mesaverde which indicates that maturity was set prior to (at maximum burial) or during early stages of structural movement. In some areas, however, the $R_{m}$ lines cut across structure indicating that maturity continued during or for some time after structural movement. It is likely that toward the deepest part of the basin, maturation at the base of the Mesaverde continued to increase during or after uplift and erosion that began $10 \mathrm{Ma}$ (Miocene). On the flanks of the basin, however, maturity patterns may have been achieved prior to uplift.

Four $R_{m}$ lines and three zones of hydrocarbon generation are shown. The 0.65 percent $R_{m}$ line is for reference, and shows the maturity of the base of the Mesaverde around the edge of the basin. The areas of the basin which have not achieved a maturity of 0.75 percent, not mature enough for significant gas generation, are shown by the light stipple pattern. The 0.75 percent $R_{m}$ line indicates the onset of significant gas generation from type III kerogen at the base of the Mesaverde. The area between 0.75 percent and 1.10 percent $R_{m}$ (darker stipple) is where one would expect to begin encountering gas generation and accumulation in Mesaverde reservoirs. The area north of 1.10 percent $R_{m}$ (darkest pattern) is the zone of maximum gas generation and expulsion. The upper limit of gas generation in the northem and deepest, undrilled part of the basin is unknown at this time. The 1.50 percent $R_{m}$ line is for reference only. 


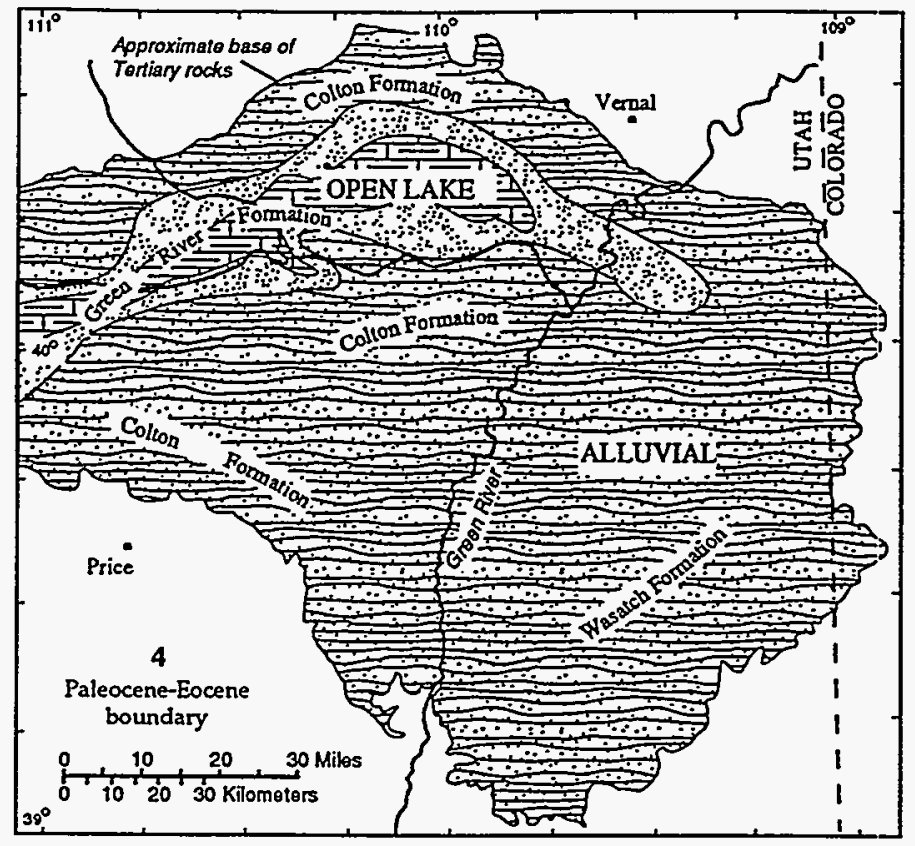

Figure 23. Paleogeographic map including depositional-facies in a zone consisting of beds adjacent and laterally equivalent to the Paleocene-Eocene boundary (modified from Fouch, 1975). The distrilution of potential reservoirs and beds of this age are limited where they pinchout against the Uncompahgre upliit a short distance southeast of the present-day course of the Green River.

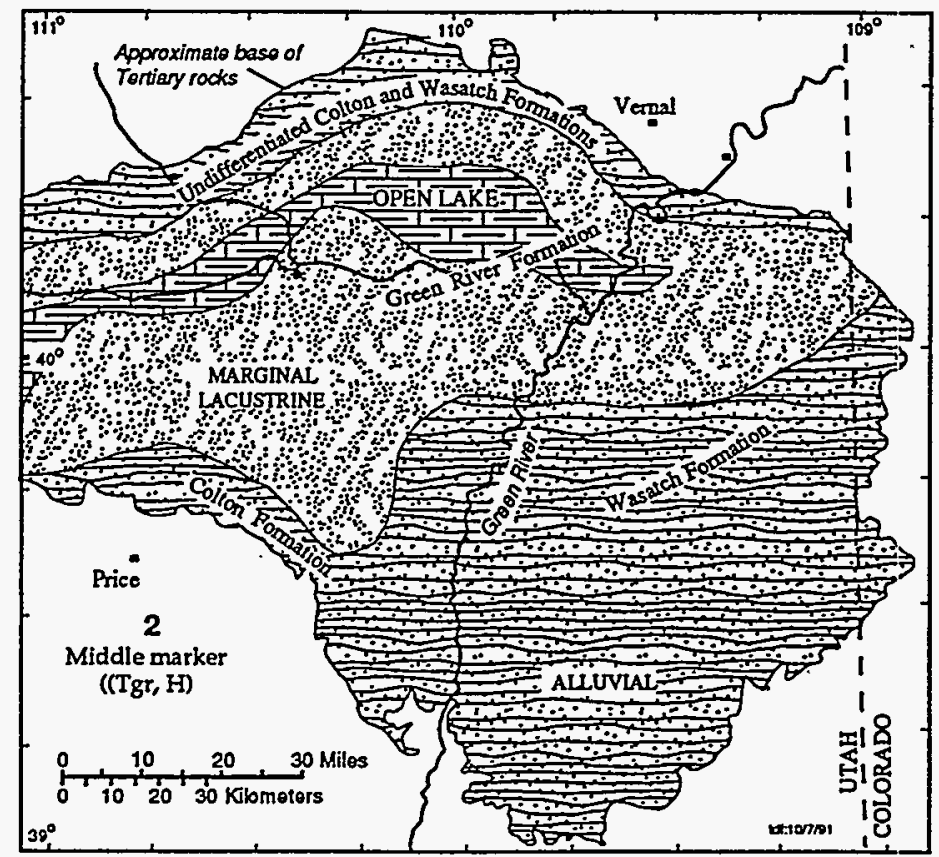

Figure 24. Paleogeographic map including depositional-facies in a zone consisting of beds adjacent and laterally equivalent to the middle marker of the Green River Formation (modified from Fouch, 1975). Middle marker - reservoirs yield large volumes of oil and gas at the extreme east end of the basin in the region of the Red Wash producing complex. Marginal-lacustrine units within this sequence contain gas in many of the eastern and northern parts of the basin. In addition, beds from this stratigraphic sequence contain tight alluvial sandstone reservoirs of the Wasatch and Colton Formations in the greater Natural Buttes producing area. 


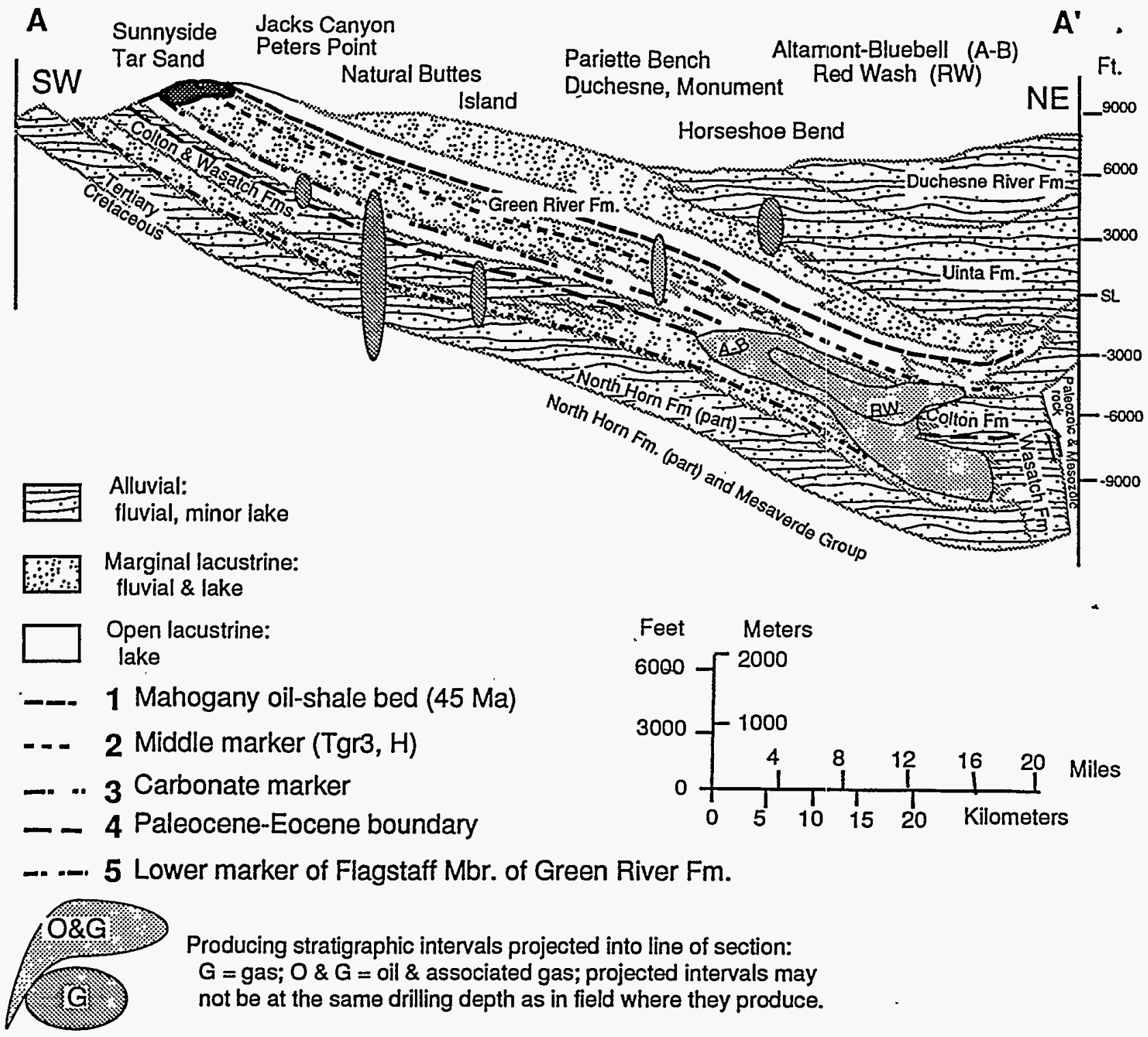

Figure 25. Cross section $A-A^{\prime}$ which extends from outcrops on the southwest flank of the Uinta Basin, through Duchesne and Altamont-Bluebell oil fields, to the north-central part of the basin (modified from Fouch, 1975). Section shows producing intervals for many of the basin's fields projected into the line of section. Stratigraphic markers are those commonly assigned to the units and follow the usage of Fouch, (1975), Fouch (1976), Ryder and others (1976), and Fouch(1981). Stratigraphic names projected into the line of section are those commonly assigned to the units and follow the usage of fouch (1976), Ryder and others (1976), Bryant (1991), and Bryant and others (1989).

The base of the Mesaverde is greater than 0.75 percent $R_{m}$ over a large area of the Uinta Basin. Except for the margins of the basin, where subsidence and burial depths were less, gas was probably being generated as Tertiary sediments were being deposited, in Paleocene or early Eocene time, and this generation continued until at least $10 \mathrm{Ma}$ when uplift and erosion began part of the basin accompanied by a regional cooling. In the deepest part of the basin, where the effect of uplift and erosion are not as great, if temperatures were still high enough, and kerogen was available (not "cooked out"), gas generation may have continued after $10 \mathrm{Ma}$ and may be continuing today. It is likely that this gas was trapped in "tight reservoirs" throughout the generation history of the Mesaverde, and the pods of high fluid pressures $(>0.5 \mathrm{psi})$ found in the basin today may mark the areas of active generation. 


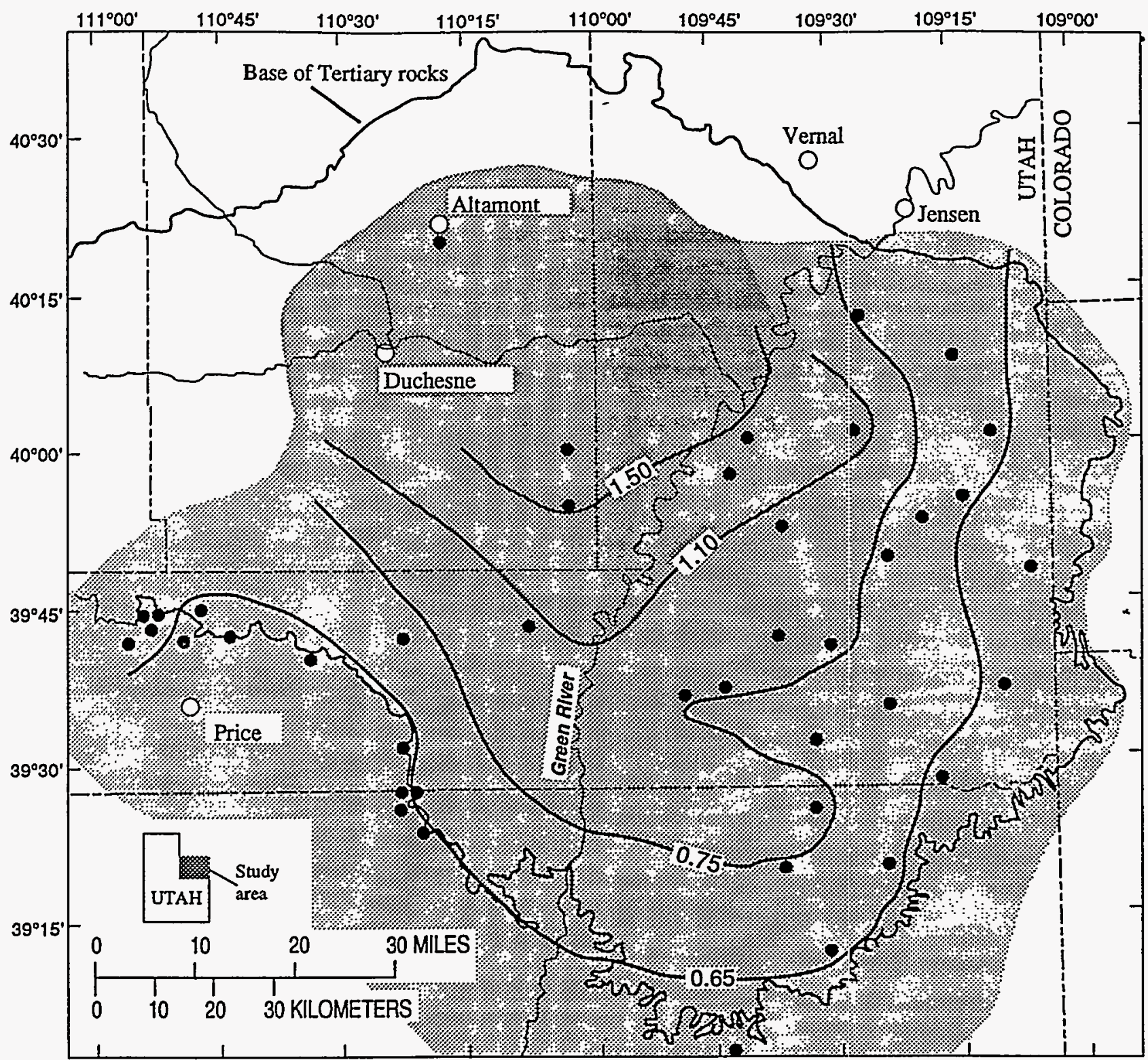

Figure 26. Vitrinite reflectance $\left(R_{f}\right)$ map showing thermal maturity on the base of the Mlesaverde Group, Uinta Basin, $U$ tah. The map indicates areas of no gas generation (light stipple pattem), onset of significant gas generation ( 0.75 percent $R_{m}$ line, and darker stipple pattern), and maximum gas generation and expulsion (1.10 percent $R_{m}$ line and darkest pattern). It is very important to note that the line described by thesurface projection of the vitrinite reflectance value $\left(R_{m}\right)>1.10$ at the base of the Mesaverde in the Uinta Basin indicates that the Tertiary and Cretaceous stratigraphic section below $3,000 \mathrm{ft} \pm$ separates those fields with hydrocarbon contacts from those without. For strataand areas whose $R_{m}<1.10$, the fields will have hydrocarbon/water contacts. We have measured $R_{m}$ values for strata over much of the basin and through much of the buried stratigraphic section as a basis for prediction.

It is very important to note that the line described by the surface projection of the vitrinite reflectance value $(\mathrm{Rm})>1.10$ at the base of the Mesaverde in the Uinta Basin indicates that the Tertiary and Cretaceous stratigraphic section below 3,000 ftt separates those fields with hydrocarbon contacts from those without. For strata and areas whose $R_{m}<1.10$, the fields will have hydrocarbon/water contacts. We have measured
$R_{m}$ values for strata over much of the basin and through much of the buried stratigraphic section as a basis for prediction.

\section{CLOSING COMMENTS}

It is important to remember that many of the steps involved in this study required the assignment of strata 
to plays and that assumptions be made in the assessment of these plays. These assignments and assumptions could be varied from that used herein. For example our definition of a play requires that the geologist group hydrocarbon accumulations in the region into geologically-based plays, that is, hydrocarbon accumulations with common characteristics. This grouping requires that we draw boundaries between plays and project those boundaries to unexplored areas using some combination of geologic parameters that can be associated with production in the fields and that can be measured in unexplored areas. For this study we have chosen to draw boundaries and measure production indices using conservation limits. However these conservative limits may serve to lower the relative resources in a play.

In this report we have used a vitrinite reflectance value $\left(R_{m}\right)$ of $1.1 \%$ as a threshold measure to draw a line between plays characterized among gas-saturated and transitional plays. For purposes of illustration and calculation, these boundaries are regarded as sharp lines even though we know that the boundaries between plays, and therefore calculated production indices, are probably gradational throughout the area of the play. Indices used to approximate play characteristics (i.e. cell success ration, EUR distribution) are probably commonly gradational from play to play. For example, one could select a value between $R_{m}$ $0.75 \%$ and $1.10 \%$ to distinguish among gas-saturated and transitional plays. In this study use of a lower threshold value of $R_{m}$ to separate plays would have the effect of increasing the area of potential higher resources because it would serve to increase the area characterized by gas-saturated rocks. However, the use of a lower value of $R_{m}$ would probably also serve to lower the cell success ration and EUR distribution for the play because it would result in the inclusion of an increased number of wells that produce water and that have lower values of ultimate recovery.

We have used past performance (i.e., cell success ratio, EUR distribution) as our primary indicator of the capacity of the strata to yield gas in the future. The EUR distribution for a play is correct for that spacing determined to be correct for the accumulation, i.e., wells recover all gas but do not drain gas in communication with another. However, in this analysis we found that spacing for play varied from area to area and only through a history of extensive drilling and production has an appropriate spacing been defined. Our EUR analysis for plays made use of data from wells that were drilled over a number of years and to fill a variety of spacing requirements. Due to the limitations of the study we did not attempt to determine separate EUR distributions for each spacing although to do so would have provided a refined basis for assessment.

For the most part, plays (or segments thereof) analyzed as a part of this study have a history of production dating back as much as 25 years. The record of production from these plays includes not only gas produced from zones completed during early periods of the fields (wells) development but also a continued addition of gas from zones or pays that were not initially discovened or connected to the wellbore and were behind-the-pipe during the formative years of production. Behind-the-pipe reserves are those determined by operators to represent discovered reserves that could be produced economically when and if they are connected to the well bore. Their recognition is based upon geophysical and petrophysical measures of secondary parameters believed by the operator to be indicators of gas that could be produced economically. Normal development of a play results in the production from both initial reserves and the addition of "behind the pipe" reserves from subsequently completed zones, and the EUR distribution for the play reflects this growth.

In this analysis we found the geologic and production information for some plays to be particularly uncertain. As a result, for these plays we accommodate these uncertainties by presenting two estimates of potential additions to reserves based upon one or more anticipated well spacings for the play and by varying parameters that reflect the uncertain factors. The uncertainties are accommodated by varying 1 ) the cell success ratio from that calculated using wells in the play, and 2) the overall limits of the play from the illustrated play boundaries (minimum and maximum number of untested cells). In some cases we have compared two or more EUR distributions for a play that are based upon wells representing such populations as all productive wells in a play, only those representing the core productive area, or in some cases a distribution selected from a geologically analogous accumulation in another area. Where more than one EUR distribution is available, we used that distribution believed by us to be most representative appropriate for this assessment. These distributions, data, assumptions, and bases for variations are provided for each play in Appendix A. 


\section{ACKNOWLEDGMENTS}

We would like to express our gratitude to the many individuals who contributed to the success of this endeavor. The U.S. Geological Survey at the request of the Karl Frohne of the U.S. Department of Energy was asked to characterize the petroleum geology of Upper Cretaceous and Tertiary strata in the Uinta Basin and to assess gas resources in their impermeable reservoirs. This report was prepared for the U.S. Department of Energy who cofunded much of this research in conjunction with the U.S. Geological Survey's Evolution of Sedimentary Basins, and Onshore Oil and Gas Programs. We are especially indebted to John Osmond and Logan MacMillan, independents, Tom Chidsey, Jr., Utah Geological Survey, and Vito Nuccio, Bill Cashion, Dudley Rice, Janet K. Pitman, and Ronald C. Johnson of the USGS who shared their expertise with us. We also wish to acknowledge the assistance of Richard Mast, Lois Williams, and Bill Beeman of the USGS in the determination of cell success ratios for each play, and Charles Spencer of the USGS for his help in identifying key petroleum plays and drawing their boundaries.

\section{REFERENCES}

Boardman, C.R., and C.F. Knutson, 1980, Reservoir characteristics in Uinta basin gas wells, U.S. Department of Energy Report DOE/ET/11399-1, p. 89 p., 26 tables, 36 figures.

Boardman, C.R., and C.F. Knutson, 1981, Uinta basin lenticular sandstone reservoir characteristics, SPE/ DOE Paper 9849, SPE/DOE Low Permeability Symposium, p. 217-222.

Crovelli, R.A., 1984, Procedures for petroleum resource assessment used by the U.S. Geological Surveystatistical and probabilistic methodology; in Masters, C.D., ed., Petroleum resource assessment: International Union of Geological Sciences, pub. no. 17, p. $24-38$.

Crovelli, R.A., 1987, Probability theory versus simulation of petroleum potential in play analysis, in Albin, S.L., and Harris, C.M., eds., Statistical and computational issues in probability modeling, Part 1: Annals of Operations Research, v. 8, p. 363-381.

Crovelli, R.A., 1988a, Multi-model approach to petroleum resource appraisal using analytic methodologies for probabilistic systems: Joumal of Mathematical Geology, v. 20, no. 8, p. 955-972.
Crovelli, R.A., 1988b, U.S. Geological Survey assessment methodology for estimation of undiscovered petroleum resources in play analysis of the Arctic National Wildlife Refuge, in Chung, C.F., Fabbri, A.G., and Sinding-Larsen, R., eds., Quantitative Analysis of Mineral and Energy Resources: Dordrecht, Holland, D. Reidel Publishing, NATO ASI Series C: Mathematical and Physical Sciences, v. 223, p. 145-160.

Crovelli, R.A., and Balay, R.H., 1986, FASP, An analytic resource appraisal program for petroleum play analysis: Computers and Geosciences, v. 12, no. 4B, p. 423-475.

Crovelli,R.A., and Balay, F..H., 1988, A microcomputer program foroil and gasiesource appraisal: Computer Oriented Geological Society, COGS Computer Contributions, v. 4, no. 3, p. 108-122.

Crovelli, R.A., and Balay, R.H., 1990a, FASPU English and metric version-Analytic petroleum resource appraisal microcomputer programs for play analysis using areservoir-engineering model: U.S. Geological SurveyOpen-File Report90-509-A, Documentation (paper copy) 25 p.; Open-File Report 90-509-B, Executable program (5.25" diskette).

Crovelli, R.A., and Balay, R.H., 1990b, PROBDIST: Probability distributions for modeling and simulation in the absence of data: U.S. Geological Survey Open-File Report 90-446-A, Documentation (paper copy) 51 p.; Open-File Report 90-446-B, Executable program (5.25" diskette).

Crovelli, R.A., and Balay, R.H., 1992, APRASAnalytic petroleum resource appraisal systemMicrocomputer programs for play analysis using a field-size model: U.'S. Geological Survey OpenFile Report 92-21-A, Documentation (paper copy) 28 p.; Open-File Report 92-21-B , Executable program (5.25" diskette).

Crovelli, R.A., and Balay, R.H., 1993, LOGRAFLognormal graph for resource assessment forecast: U.S. Geological Survey Open-File Report 92-679A, Documentation (paper copy) 30 p; Open-File Report 92-679-B, Executable program (5.25" diskette).

Fouch, T.D., Wandrey, C.J., Taylor, D.J., Butler, W.C., Miller, J.J., Prensky, S.E., Boone, L.E., Schmoker, J.W., Crovelli, R.A., and Beeman, W.R., 1994, Oil and Gas Resources of U.S. Naval Oil Shale Reserves 1 and 3, Colorado, and Reserve 2, Utah: U.S. Geological Survey Open-File Report 94-427, 158 p. 
Fouch, T.D., Nuccio, V.F., and Chidsey, T.C., Jr., eds., 1992a, Hydrocarbon and Mineral Resources of the Uinta Basin, Utah and Colorado, Utah Geological Association Guidebook 20: Salt Lake City, Utah, U.S.A., Utah Geological Association, hardbound, $366 \mathrm{p}$.

Fouch, T.D., Nuccio, V.F., Anders, D.E., Rice, D.D., Pitman, J.K., and Mast, R.F., [in press], The Green River Petroleum System, Uinta Basin, Utah, USA, in Magoon, L.B., and Dow, W.C., eds., The Petroleum System-From Source to Trap: American Association of Petroleum Geologists Memoir 60, Chapter 25,

Fouch,T.D., Nuccio, V.F., Osmond,J.C., MacMillan,L., Cashion, W.B., and Wandrey, C.J., 1992b, Oil and Gas in uppermost Cretaceous and Tertiary rock, Uinta Basin, Utah, in Fouch, T.D., Nuccio, V.F., and Chidsey, T.C., Jr., eds., Hydrocarbon and Mineral Resources of the Uinta Basin, Utah and Colorado, Utah Geological Association Guidebook 20: Salt Lake City, Utah, U.S.A., Utah Geological Association, p. 9-47.

Fouch, T.D., Wandrey, C.J., Pitman, J.K., Nuccio, V.F., Schmoker, J.W., Rice, D.D., Johnson, R.C., and Dolton, G., L., 1992c, Natural gas accumulations in low-permeability Tertiary and Cretaceous (Maastrichtian-Campanian) rock, Uinta Basin, Utah: U.S. Department of Energy Report DOE/MC/20422-3051 (DE92001132), 81 p.

Franczyk, K. J., Fouch, T. D., Johnson, R. C., and Molenaar, C. M., in press, Cretaceous and Tertiary paleogeographic reconstructions for the UintaPiceance study area: U.S. Geological Survey Bulletin 1787-Q, $37 \mathrm{p}$.

Franczyk, K.J., Pitman, J.K., Cashion, W.B., Dyni, J.R., Fouch, T.D., Johnson, R.C., Chan, M.A., Donnell, J.R., Lawton, T.F., and Remy, R.R., 1989, Evolution of resource-rich foreland and intermontane basins in eastem Utah and westem Colorado, 28th Intemational Geologic Congress Field Trip Guidebook T-324, 53 p.

Hartmann, D.J., and MacMillan, L., 1992, Petrophysics of the Wasatch Formation and Mesaverde Group, Natural Buttes producing area, Uinta Basin, Utah, in Fouch, T.D., Nuccio, V.F., and Chidsey, T.C., ed., Hydrocarbon and Mineral Resources of the Uinta Basin, Utah and Colorado, Utah Geological Association Guidebook 21: Salt Lake City, Utah U.S.A., Utah Geological Association, p. 175-192.
Hodges, L.T., and Knutson, C.F., 1981, Tight gas sandstone channel continuity and directivity, Upper Cretaceous Lance and Paleocene, Greater Green River Basin, Wyoming, in Proceedings of the 1981 SPE/DOE Symposium on Low Permeability Gas Reservoirs,: Society of Petroleum Engineers and U.S. Department of Energy, SPE/DOE paper 9844, p. $165-176$.

Johnson R.C., and Rice, D.D., 1990, Occurrence and Geochemistry of natural gases, Piceance basin, northwest Coloraido: American Association of Petroleum Geologists Bulletin, v. 74, p. 805-829.

Johnson, R.C., and Nuccio, V.F., 1986, Structural and thermal history of the Piceance Creek basin, westem Colorado, in relation to hydrocarbon occurrence in the Mesaverde Group, in Spencer, C.W., and Mast, R.F., eds., Geology of tight gas reservoirs: American Association of Petroleum Geologists Studies in Geology No. 24, p. 165-205.

Johnson, R.C., and Nuccio, V.F., in press, A surface vitrinite reflectancesstudy of the Uinta-Piceance basin area, westem Colorado and eastem Utah and its implications for the developmentofLaramide basins and uplifts: U.S: Geological Survey Bulletin, 48 p., 24 figures, 1 plate.

Johnson, R.C., Crovelli, R.A., Spencer, C.W., and Mast, R.F., 1987, An assessment of gas resources in lowpermeability sandstones of the Upper Cretaceous Mesaverde Group, Piceance basin, Colorado: U.S. Geological Survey Open-File Report 87-357, 165 p.

Johnson, Ronald C., 1987, Geologic history and hydrocarbon potential of Late Cretaceous-age, low-permeability reservoirs, Piceance basin, western Coloraclo, v. DOE/MC/20422-2337 (DE87006476), n. Distribution Category UC-132, $97 \mathrm{p}$.

Keighin, C.W., and Fouch, T.D., 1981, Depositional environments and diagenesis of some nonmarine Upper Cretaceous reservoir rocks, Uinta basin, Utah, in .Ethridge, F.G., and Flores, R.M., eds., Recent and Ancient Nonmarine Depositional Environments: Models for Exploration: Society of Economic Paleontologists and Mineralogists Special Publication No. 31, p. 109-125.

Knutson, C.F., and L. T. Hodges, 1981, Development of techniques for optimizing selection and completion of western tight gas sands, comparison of core, geophysical $\mathrm{log}$, and outcrop information, phase III report, U.S. Department of Energy Report DOE/BC10005-3, 54 p., 14 figs, 7 plates. 
Knutson, C.T., Hodges, L.T., and Righter, S.B., 1981, Permeability, petrography and small scale structural element analysis of Upper Cretaceous channel sandstone from the Rock Springs Uplift and Wind River Basin, Wyoming, in Proceedings of the 1981 SPE/DOE Symposium on Low Permeability Gas Reservoirs,: Society of Petroleum Engineers and U.S. Department of Energy, v. SPE/DOE paper 9874, p. $427-436$.

MacMillan, L., 1992, A heuristic method for reserve analysis in the greater Natural Buttes producing area, Uinta Basin, Utah, in Fouch, T.D., Nuccio, V.F., and Chidsey, T.C., ed., Hydrocarbon and Mineral Resources of the Uinta Basin, Utah and Colorado: Utah Geological Association Guidebook 20: Salt Lake City, Utah U.S.A., Utah Geological Association, p. $165-174$

Nuccio, V.F., and Fouch, T.D., 1992, Thermal maturity of the Mesaverde Group, Uinta Basin, Utah: in Magoon, L.B., ed., The Petroleum System-Status of Research and Methods 1992: U.S. Geological Survey Bulletin 2007, p. 70-78.

Nuccio, V.F., and Johnson, R.C., 1986, Thermal maturity map of the Lower part of the Upper Cretaceous Mesaverde Group, Uinta Basin, Utah: U.S. Geological Survey Miscellaneous Field Studies Map MF-1842, one plate.

Nuccio, V.F., and Johnson, R.C., 1988, Surface vitrinite reflectance map of the Uinta, Piceance, and Eagle basins area, Utah and Colorado: U.S. Geological Survey Miscellaneous Field Studies Map MF2008-B, 21 p., one plate.

Nuccio, V.F., Schmoker, J.W., and Fouch, T.D., 1992, Thermal maturity, porosity, and lithofacies relationship applied to gas generation and production in Tertiary and Cretaceous low-permeability (tight) sandstones, Uinta Basin, Utah, in Fouch, T.D., Nuccio, V.F., and Chidsey, T.C., Jr., eds., Hydrocarbon and Mineral Resources of the Uinta Basin, Utah and Colorado: Utah Geological Association Guidebook 20: Salt Lake, City, Utah, U.S.A., Utah Geological Association, p. 77-94.

Osmond, J.C., 1992, Greater Natural Buttes gas field, Uintah County, Utah, in Fouch, T.D., Nuccio, V.F., and Chidsey, T.C., ed., Hydrocarbon and Mineral Resources of the Uinta Basin, Utah and Colorado: Utah Geological Association Guidebook 21: Salt Lake City, Utah U.S.A., Utah Geological Association, p.143-163.

Pitman, J.K., Anders, D.E., Fouch, T.D., and Nichols, D.J., 1986, Hydrocarbon potential of nonmarine Upper Cretaceous and Lower Tertiary rocks, eastem
Uinta basin, Utah, in Spencer, C.W., and Mast, R.F., eds., Geology of Tight: Gas Reservoirs: American Association of Petroleum Geologists Studies in Geology No. 24, p. 235-252.

Pitman, J.K, Fouch, T.D., and Goldhaber, M.B., 1982, Depositional setting and diagenetic evolution of some Tertiary unconventional. reservoir rocks, Uinta basin, Utah: American Association of Petroleum Geologists Bulletin, v. 66 , no. 10, p. 1581-1596.

Pitman, J.K., Franczyk, K.J., and Anders, DE., 1987, Marine and nonmarine gas-bearing rocks in Upper Cretaceous Blackhawk and Neslen Formations, eastemUinta Basin, Utah: Sedimentology, diagenesis, and source rock potential: AmericanAssaciationofPetroleum Geologists Bulletin, v. 71, no. 1, p. 76-94.

Pitman, J.K., Franczyk, K.J., and Anders, D.E., 1988, Diagenesis and burial history of nonmarine Upper Cretaceous rocks in the central Uinta basin, Utah: U.S. Geological Survey Bulletin 1787-D, 24 p.

Rice, D.D., Fouch, T.D., and Johnson, R.C., 1992, Influence of source rock type, thermal maturity, and migration on composition and distribution of natural gases, Uinta Basin, Utah, in Fouch, T.D., Nuccio, V.F., and Chidsey, T.C., Jr., eds., Hydrocarbon and Mineral Resources of the Uinta Basin, Utah and Colorado: Utah Geological Association Guidebook 20: Salt Lake City, Utah, U.S.A., Utah Geological Association, p. 95-110

Schmoker, J.W., Nuccio, VF., and Pitman, J.K., 1992 , Porosity trends in predominantly nonmarine sandstones of the Upper Cretaceous Mesaverde Group, Uinta and Picearice basins, Utah and Colorado, in Fouch, T.D., Nuccio, V.F., and Chidsey, T.C., eds., Hydrocarbon and Mineral Resources of the Uinta Basin, Utah and Colorado: Utah Geological Association Guidebook 21: Salt Lake, City, Utah, U.S.A., Utah Geological Association, p. 111-122.

Spencer, C.W., and Wilson, R.J., 1988, Petroleum geology and principal exploration plays in the Uinta-Piceance-Eagle basins province, Utah and Colorado, U.S. Geological Survey Open-File Report 88-450, 35 p.

Spencer, Charies W., 1987, Hydrocarbon generation as a mechanism for overpressuring in Rocky Mountain region, American Association of Petroleum Geologists Bulletin, v. 71, n. 4, p. 368-388, 17 Figs. Wesley, J.B., Wandrey, C.J., and Fouch, T.D., 1993, Principal drill stem test database (UBDST) and documentation: analysis of Uinta Basin, Utah gas-bearing Cretaceous and Tertiary strata: U.S. Geological Survey Open-file Report 93-193, 19 pages, $1-31 / 2$ inch diskette. 


\section{APPENDIX A}

\section{PLAY DEFINITIONS, STRATIGRAPHIC COMPONENTS, EUR DISTRIBUTIONS, AND ANCILLARY DATA}

Plays in italics frequently contain reservoirs whose values of matrix permeability frequently are $0.1 \mathrm{md}$ or below when extrapolated to subsurface conditions.

Stratigraphic succession of plays in the USGS-DOE Tight Gas Assessment

$\begin{array}{lllllll}\text { Play } 2015 & 2016 & 2017 & 2018 & & 2019 & 2020 \\ \text { Play } 2018 & 2018 & 2019 & \text { none } & \text { none } & \text { none }\end{array}$


This page intentionally left blank. 
Plays 2015 \& $2016 \quad$ Lower Tertiary Wasatch Formation Gas-Saturated

North Horn, Ohio Creek, Paleocene Series, Wasatch, Wasatch A, Wasatch Tongue, Uteland Buttes, Chapita, Colton, Buck Canyon

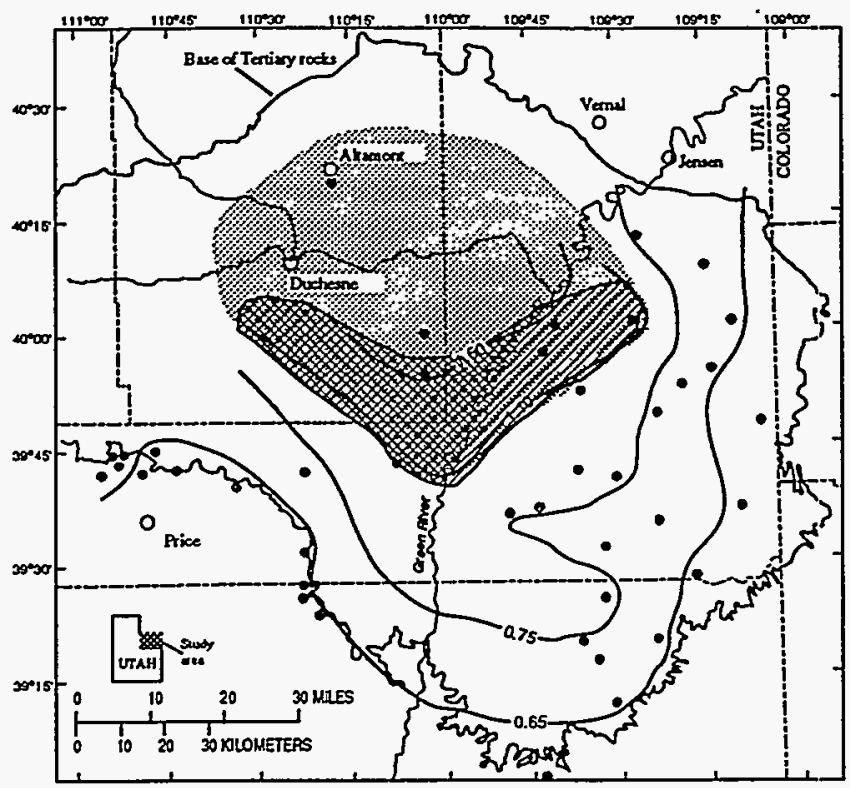

Plays 2015 \& 2016: Gas-Saturated Wasatch Formation

Area of Play 2015: Wasatch Production (includes Uteland Butte, Chapita, \&. Buck Canyon zones) from this area:

Area of Play 2016: Wasatch Production (includes Utaland Butto, Chapita, 2. Buck Canyon zones) from this area:

Area of maximum gas generation from Type III orgainic matter near the base of the Mesaverde Group (Ro $>1.10 \%$ ).

- Control point for measures of vitrinite rellectanco

\section{Considerations for Play 2015 (Wasatch saturated east)}

* Includes the main producing area of the greater Natural Buttes field.

* The accumulation is part of a displacement bubble in which free water has been displaced from the gassaturated accumulation. Most of the gas is being generated within the underlying coal-bearing part of the Cretaceous Mesaverde Group and migrating to Wasatch strata. Some gas near the northern limits of the play originated as gas associated with Green River Formation source rocks.

* Updip limit of the continuous-gas accumulation is coincident with the thermal maturity of the underlying coal-bearing part of the Cretaceous Mesaverde Group $\left(R_{0}=1.1\right)$. Downdip limit is determined by the transition to the oil-bearing Green River Formation. A continuous-gas accumulation is not maintained at depths less than $3000 \mathrm{ft}$.

* Minimum number of untested cells excludes 1) area south of T. 10 S., 2) restricts downdip limit of play

* Maximum number of untested cells includes 1) all of the area of play 2016,2) some area east of Natural Buttes now assumed to contained Green River Formation associated gas in accumulations with gas/water contacts.

* Sandstone reservoir bodies on outcrop consistent with 80 acre or less spacing 


\section{USGS-DOE TIGHT GAS ASSESSMENT \\ DATA FORM FOR ASSESSMENT OF CONTINUOUS-TYPE ACCUMULATIONS}

Province Geologist:_Fouch/Schmoker Province Name, No.: Uinta-Piceance (20)

Date: $7 / 18 / 94$ Play Name, No.: Tertiary (Wasatch Fm) gas-east(Uinta) (2015)

Scenario: cells $=160$ acres; .60 weight; uniform cell \# distribution

Play Probability (0-1.0) (II A): 1.0

Stop here if play does not exceed 0.10 (II B)

Cells (III)

Cell Size (III A1): 160 acres;

Area of Play (III A2): $310 \mathrm{mi}^{2}$

No. of productive cells (III B): 433

No. of untested cells (III D): 748

Minimum possible number of untested cells (III E1): 290

$0.25 \mathrm{mi}^{2}$ (acres $\left./ 540\right)$

Total no. of cells (III A3): 1240

No. of nonproductive cells (III C): 59 50 th fractile

Maximum possible number of untesed cell (III) $\frac{290}{1927}$ 100th fractile

Success ratio $(0-1.0)$ (IV): .88

0) (IV):

EUR probability distribution $\left(\mathrm{V}^{*}\right)$ :

Fractile: $\quad \begin{gathered}\text { Minimum } \\ \text { 100th }\end{gathered}$ (95th)

EUR (BO or

MMCF)

$0 \quad(32)$

(75th)

Median

50th

(25th)

(5th)

$\operatorname{Max}$

$(520)$

$1100(1900)(3300)$

6500

\section{USGS-DOE TIGHT GAS ASSESSMENT}

\section{DATA FORM FOR ASSESSMENT OF CONTINUOUS-TYPE ACCUMULATIONS}

Province Geologist: Fouch/Schmoker

Province Name, No.: Uinta-Piceance (20)

Date:_7/18/94_Play Name, No.:_Tertiary (Wasatch Fm) gas-east(Uinta) (2015)

Scenario: cells $=80$ acres; .40 weight; uniform cell \# distribution

Play Probability (0-1.0) (II A): 1.0

Stop here if play does not exceed 0.10 (II B)

Cells (III)

Cell Size (III A1): $80 \quad$ acres;

Area of Play (III A2): $\frac{310}{\mathrm{mi}^{2}}$

No. of untested cells (III D): $\frac{1945}{1945}$

$.125 \mathrm{mi}^{2}$ (acres/640)

Total no. of cells (II A3): 2480

No. of nonproductive cells (II C): 62

Minimum possible number of untested cells (III E1): 989

100 th fractile

Maximum possible number of untested cells (III E2): 4388 0th fractile

Success ratio (0-1.0) (IV): .88

EUR probability distribution $\left(\mathrm{V}^{*}\right)$ :

Fractile: Minimum

EUR (BO or

100 th $\quad(95$ th $)$

(75th) Median

50th

(25th)

(5th)

$\operatorname{Max}$

MMCF)

$0 \quad(32)$

(520) 1100

$(1900)(3300) \quad 6500$ 
Plausible scenarios for Wasatch play 2015

\begin{tabular}{llllllll}
\hline Mean & F95 & F75 & F50 & F25 & F05 & $\begin{array}{c}\text { EUR/cell } \\
\text { (mean) }\end{array}$ \\
\hline \multicolumn{7}{l}{ Wasatch Play } \\
2015 & without Gas/Water Contacts \\
3.31 & 1.74 & 2.45 & 3.11 & 3.95 & 5.56 & 1.41 & 0.4 probability, 80 acres \\
1.34 & 0.64 & 0.95 & 1.25 & 1.65 & 2.46 & 1.4 & 0.6 probability, 160 acres \\
\hline
\end{tabular}

Source for well data:

Notes:

Screen Data:
226

$45(20 \%)$

Total number of wells used in EUR distribution:

No pressure data available. Plot of EUR vs. Production date indicated no learning curve over time. EUR calculations reflect current spacing

Wasatch Formation $>3,000 \mathrm{ft}$ depth to top of perforations

< 1991 production start date, drilling history 1976-1990

Wells were selected at random taking into account above

Inactive wells included

Total number of wells that meet screening criteria:

Decline curve analysis (DCA)

Calculation of EUR:

Assumptions:

No backpressure effects, radial flow, producing in depletion stage, cumulative effects o factors altering production in history $=$ cumulative effects in future, etc.,

Segmented exponential declines are used.

Life of a well is assumed to be 35 years maximum or will produce until an economic limit of $10 \mathrm{MCFD}$ is reached. If necessary, a constant decline rate is imposed during the last five years to force the production rate to the economic limit of 10 MCFD in year 35.

Inactive wells do no resume production in this analysis.

A consistent history of downtime for a given well was reflected in the production forecast for that well (play 2015 only). 


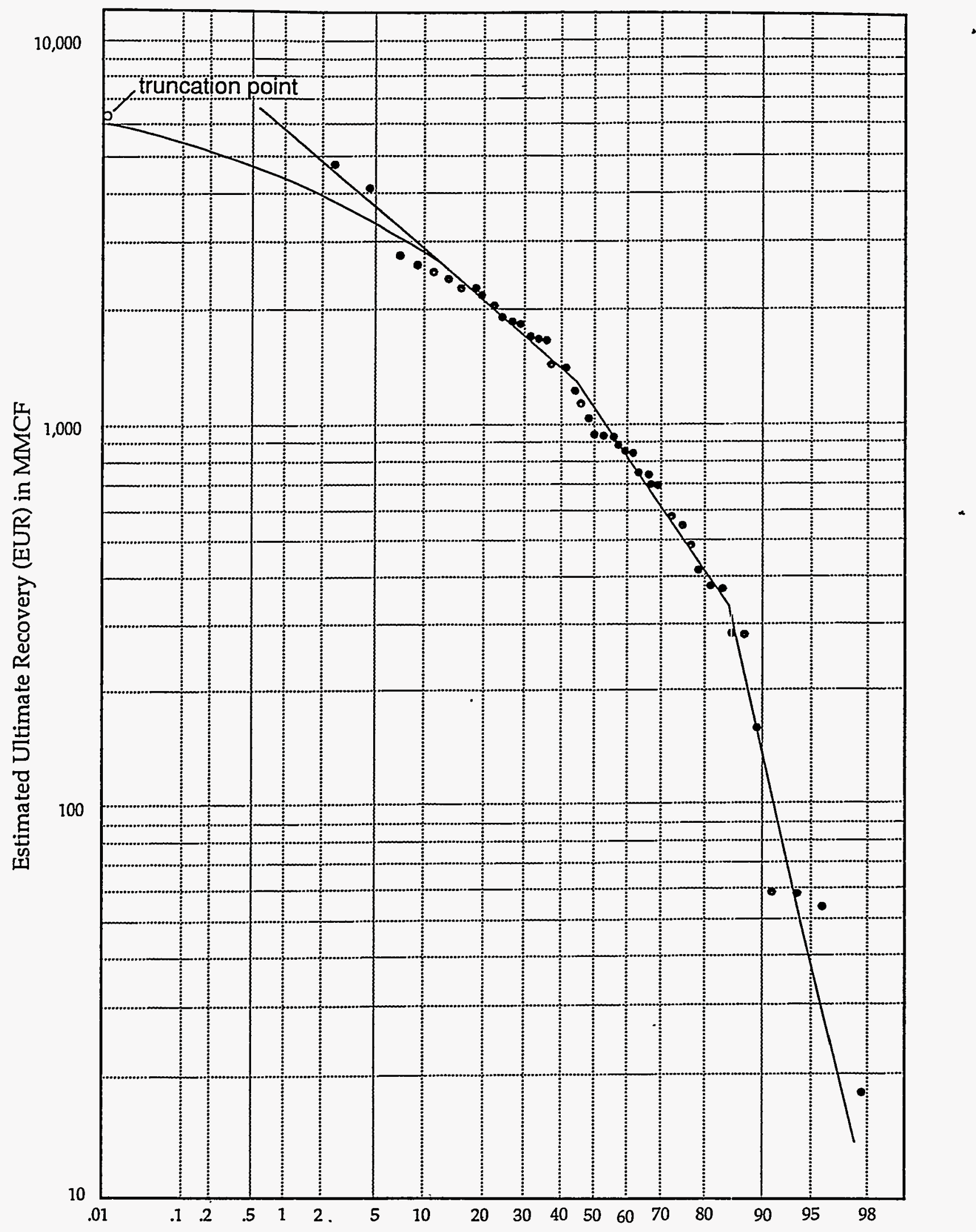

Percent of Cells in Play 2015 (Wasatch east) with Higher Estimated Ultimate Recovery (EUR) 


\section{Considerations for Play 2016 (Wasatch saturated west)}

* Includes the Wasatch, Colton, and North Horn Formations west of the Green River.

* Geologic scenario differs from that of play 2015 (Wasatch east) in that sandstone (reservoir) thickness and number decreases to the west and north, and a northwest-thickening wedge of lower Tertiary strata separates Tertiary reservoir beds from primary source rocks in the Cretaceous Mesaverde Group. These differences are primarily expressed in the success ratios of the two plays with the values being gradational between them.

* Updip limit of the continuous-gas accumulation is coincident with the thermal maturity of the underlying coal-bearing part of the Cretaceous Mesaverde Group $\left(R_{0}=1.1\right)$. Downdip limit is determined by the transition to the oil-bearing Green River Formation. A continuous-gas accumulation is not maintained at depths less than $3000 \mathrm{ft}$.

* Minimum number of untested cells assumes that play will only be valid near the Natural Buttes field

* Maximum number of untested cells assumes that the margins of the play are expanded due to uncertainty in mapping $\mathrm{R}_{0}$.

\section{USGS-DOE TIGHT GAS ASSESSMENT}

\section{DATA FORM FOR ASSESSMENT OF CONTINUOUS-TYPE ACCUMULATIONS}

Province Geologist:_Fouch/Schmoker

Province Name, No.: Uinta-Piceance (20)

Date:_ $7 / 18 / 94$ Play Name, No.: Tertiarv (Wasatch Fm) gas-west (Uinta) (2010)

(codes in parenthesis, such as IV B, refer to the procedure outline)

Scenario: cells $=160$ acres; .60 weight; uniform cell\# distribution

Play Probability (0-1.0) (II A): $1.0 \quad$ Stop here if play does not exceed 0.10 (II B)

Cells (III)

Cell Size (III A1): $160 \quad$ acres;

Area of Play (III A2): $283 \mathrm{mi}^{2}$

No. of productive cells (III B): 8

No. of untested cells (III D): $\frac{1102}{10}$

Minimum possible number of untested cells (III E1): 90 100th fractile

Maximum possible number of untested cells (III E2): 1704 Oth fractile

Success ratio (0-1.0) (IV): 30

EUR probability distribution $\left(\mathrm{V}^{*}\right)$ :

\begin{tabular}{|c|c|c|c|c|c|c|c|}
\hline & Minimum & & & Median & & & $\operatorname{Max}$ \\
\hline $\begin{array}{l}\text { Fractile: } \\
\text { EUR (BO or }\end{array}$ & 100 th & (95th) & (75th) & 50 th & (25th) & (5th) & 0th \\
\hline MMCF) & 0 & $(230)$ & (670) & 1080 & $(2050)$ & $(2650)$ & 4500 \\
\hline
\end{tabular}




\section{USGS-DOE TIGHT GAS ASSESSMENT \\ DATA FORM FOR ASSESSMENT OF CONTINUOUS-TYPE ACCUMULATIONS}

Province Geologist: Fouch/Schmoker

Province Name, No.: Uinta-Piceance (20)

Date: $7 / 18 / 94$

Play Name, No.: Tertiary (Wasatch Fm) gas-west(Uinta) (2016)

(codes in parenthesis, such as IV B, refer to the procedure outline)

Scenario: cells $=80$ acres; .40 weight; uniform cell \# distribution

Play Probability (0-1.0) (II A): 1.0

Stop here if play does not exceed 0.10 (II B)

Cells (III)

Cell Size (III A1): $80 \quad$ acres;

Area of Play (III A2): $283 \mathrm{mi}^{2}$

No. of productive cells (III B): $\underline{8}$

$.125 \mathrm{mi} 2$ (acres/640)

No. of untested cells (III D): 2234

Total no. of cells (III A3): _2264

No. of nonproductive cells (.II C): 22

Minimum possible number of untested cells (III E1): 190 100th fraclile

Maximum possible number of untested cells (III E2): $\quad 3452$ 0th fractile

Success ratio (0-1.0) (IV): .30

EUR probability distribution $\left(\mathrm{V}^{*}\right)$ :

\begin{tabular}{|c|c|c|c|c|c|c|c|}
\hline & Minimum & & & Median & & & $\operatorname{MLax}$ \\
\hline $\begin{array}{l}\text { Fractile: } \\
\text { EUR (BO or }\end{array}$ & 100 th & (95th) & (75th) & 50th & (25th) & (5th) & 0:h \\
\hline MMCF) & 0 & $(230)$ & (670) & 1080 & $(2050)$ & (2650) & $4: 500$ \\
\hline
\end{tabular}

Plausible scenarios for Wasatch play 2016

\begin{tabular}{|c|c|c|c|c|c|c|c|}
\hline Mean & F95 & F75 & F50 & F25 & F05 & $\begin{array}{r}\text { EUR/c } \\
\text { (mea }\end{array}$ & \\
\hline \multicolumn{8}{|c|}{ Wasatch Play 2016 without Gas/Water Contacts } \\
\hline $\begin{array}{l}0.74 \\
0.36\end{array}$ & $\begin{array}{l}0.38 \\
0.14\end{array}$ & $\begin{array}{l}0.47 \\
0.23\end{array}$ & $\begin{array}{l}0.66 \\
0.32\end{array}$ & $\begin{array}{l}0.91 \\
0.45\end{array}$ & $\begin{array}{l}1.47 \\
0.73\end{array}$ & $\begin{array}{l}1.35 \\
1.35\end{array}$ & $\begin{array}{l}0.4 \text { probability, } 80 \text { acres } \\
0.6 \text { probability, } 160 \text { acres }\end{array}$ \\
\hline
\end{tabular}

Notes: See play 2015

Total number of wells that meet screening criteria: One well in play area in the PI database. Analog production area is T1OS, R. 19E, the westernmost Wasatch production from Play 2015, east of the Green River. Fifty wells meet criteria.

Total number of wells used in the EUR Distribution: 41 (erratic production history and excessive downtime prevented DCA of some wells)

Calculation of EUR: see play 2015. 


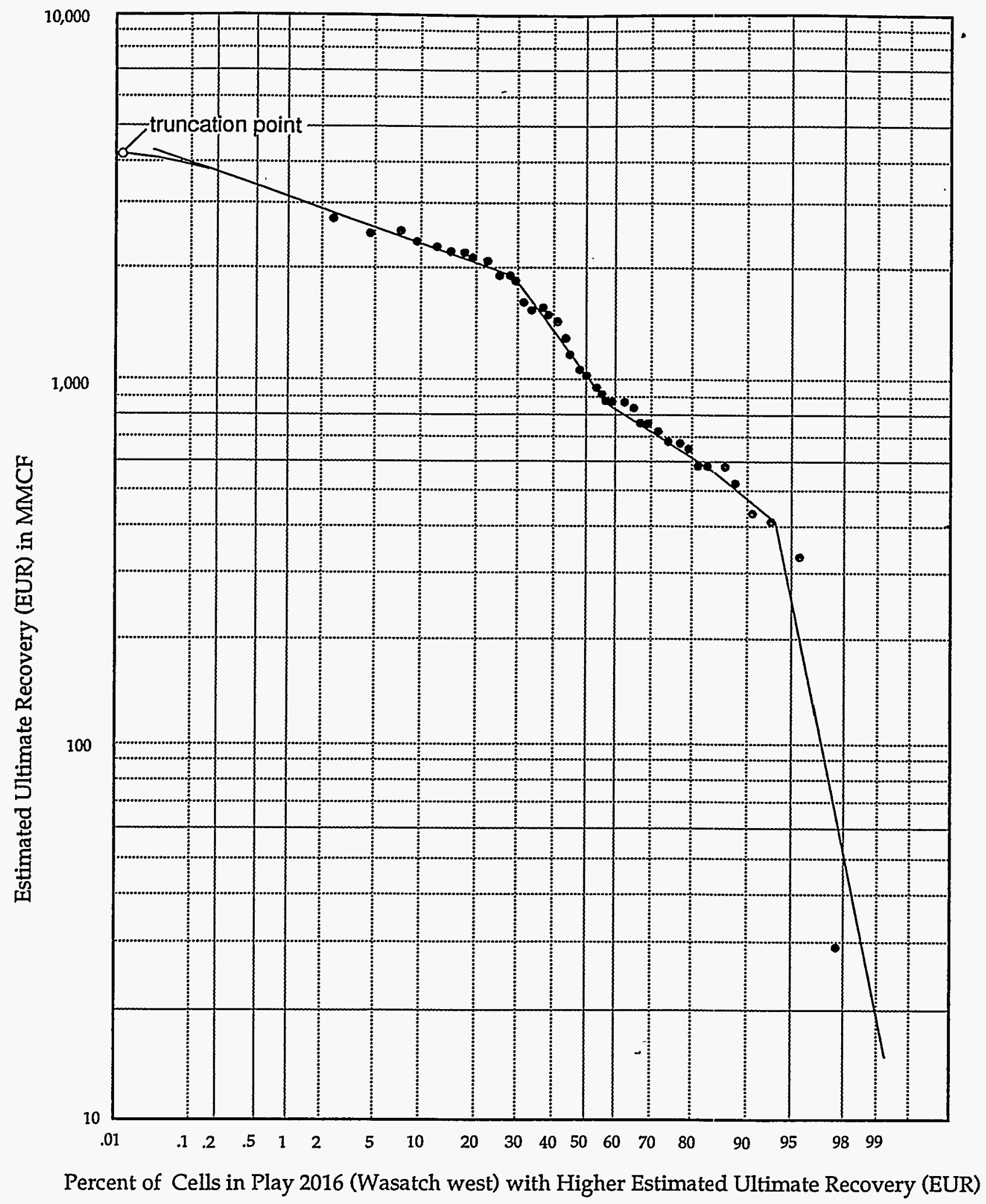


Play 2017: Lower Tertiary Wasatch Formation: Gas with water contacts

North Horn, Ohio Creek, Paleocene Series, Wasatch, Wasatch A, Wasatch Tongue, Uteland Buttes, Chapita, Colton, Buck Canyon -

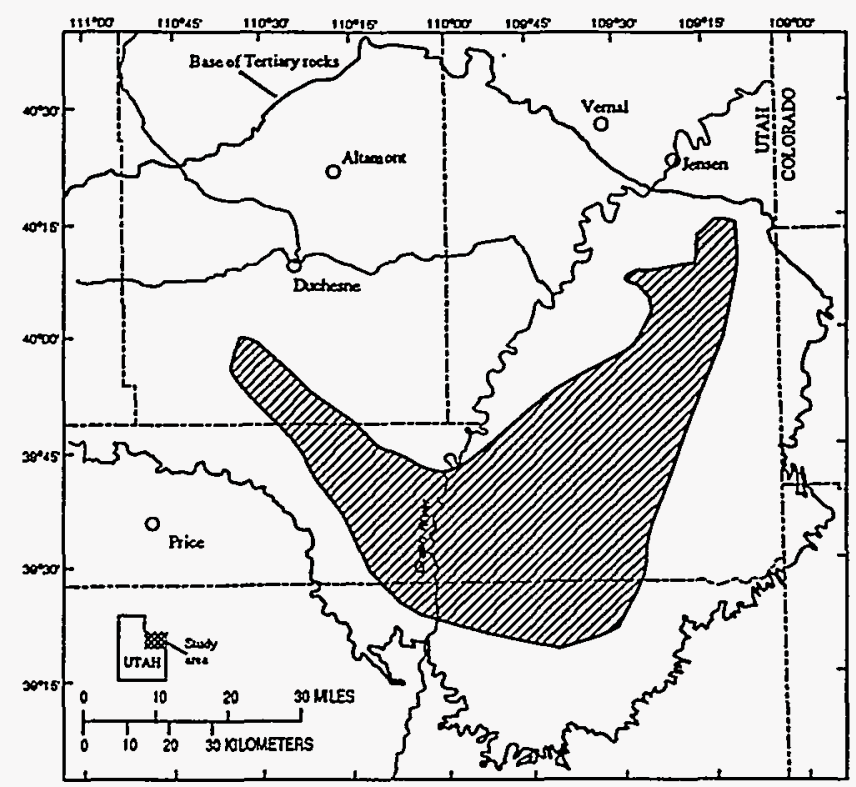

Play 2017: Gas with water contacts: Wasatch Formation

Area of Play 2017: Wasatch Production (includes Uteland Butte, Chapita, \& Buck Canyon zonos).

\section{Considerations for Play 2017 (Wasatch transition)}

* Play is located at the updip margin of a classic basin-centered gas in the Mesaverde Group. The plays consists of mixed stratigraphic and structural accumulations of gas in sandstone reservoirs of the lower Tertiary section.

* Free water seems to coexists with zones of continuous gas saturation. Over much of area gas is found on structural highs and strata are water-bearing in lows. However, toward the northem and lower limits of the play, gas-saturated strata are found locally in structural high and low positions.

* Play contains reservoirs whose matrix permeability commonly exceeds 0.1 md (tight:) but other potential saturated reservoirs may be less permeable $(<0.1 \mathrm{md}=$ tight $)$. Most of the reservoirs are not tight.

* Few wells in play area.

* Areal extent of sandstone reservoir bodies on outcrop is consistent with 80 acre or less spacing

* EUR distribution for play is difficult to determine because of the transition from continuous-phase to mixed types of accumulations. In this study we use a distribution and success ratio drawn from wells across the study area as a suitable approximation of the mixed population.

* Assessment methodology described in this report for continuous saturation accumulations is used for this play even though some areas and strata of play consists of mixed stratigraphic and structural accumulations. As a result spacing for play will vary by field and spacing variations are used to establish maximum and minimum numbers of untested cells.

* Minimum number of untested cells assumes that most of the accumulations in the play will utilize 640 -acre spacing but that most of the play is saturated.

* Maximum number of untested cells assumes that most of the accumulations in the play will utilize 40-acre spacing and that most of the play is saturated. 


\section{USGS-DOE TIGHT GAS ASSESSMENT' \\ DATA FORM FOR ASSESSMENT OF CONTINUOUS-TYPE' ACCUMULATIONS}

Province Geologist: Tom Fouch

Province Name, No.:_Uinta-Piceance

Date: $2 / 25 / 94$

Play Name, No.: Wasatch Gas/Water Contacts, 2017

(codes in parenthesis, such as IV B, refer to the procedure outline)

368 records at cell size of 160 acres $=$ cells tested-most successful near sat gas so degraded for other area

Play Probability (0-1.0) (II A): 1 Stop here if play does not exceed: 0.10 (II B)

Cells (III) Cell Size (III A1): $160(640-40) \quad$ acres;

Area of Play (III A2): $1434 \mathrm{mi}^{2}$

$\mathrm{mi}^{2}$ (acres/640)

No. of productive cells (III B): 162

Total no. of cells (III A3): 5736

No. of untested cells (III D): 5368 50th fractile

Minimum possible number of untested cells (III E1): 1342 100th fractile

Maximum possible number of untested cells (III E2): 21,472 Oth fiactile

Success ratio (0-1.0) (IV): .30

EUR probability distribution $\left(\mathrm{V}^{*}\right)$ :

\begin{tabular}{|c|c|c|c|c|c|c|c|}
\hline & Minimum & & & Median & & & $\operatorname{Max}$ \\
\hline $\begin{array}{l}\text { Fractile: } \\
\text { EUR (BO or }\end{array}$ & 100 th & (95th) & (75th) & 50th & (25th) & (5th) & Oth \\
\hline MMCF) & 0 & (11) & $(90)$ & 300 & $(1000)$ & $(2550)$ & 4000 \\
\hline
\end{tabular}

Notes: Divided area into 21 segments; spanning the drilling history, $40 \%$ of wells in each area were randomly selected for analysis; inactive wells included. Repetitive downtime is not in forecast.

Total number of wells that meet screening criteria:

Total wells used in EUR Distribution:

$51(40 \%)$

Calculation of EUR: See play 2015. 


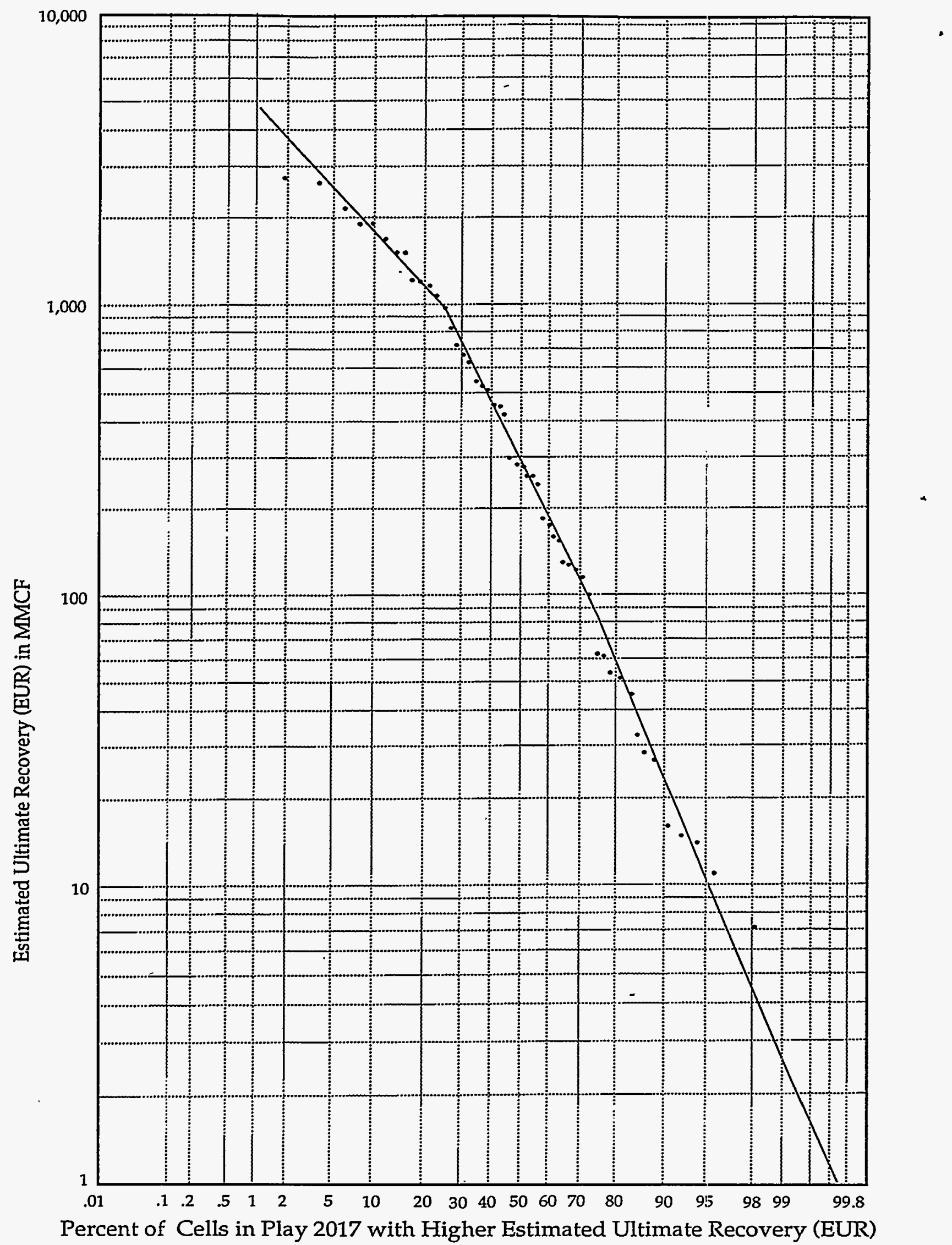


Mesaverde, Castlegate, Rim Rock, Sego, Tuscher, Farrer, Buck Tongue, Blackhawk, Price River, Cretaceous undifferentiated, Neslen, Bluecastle

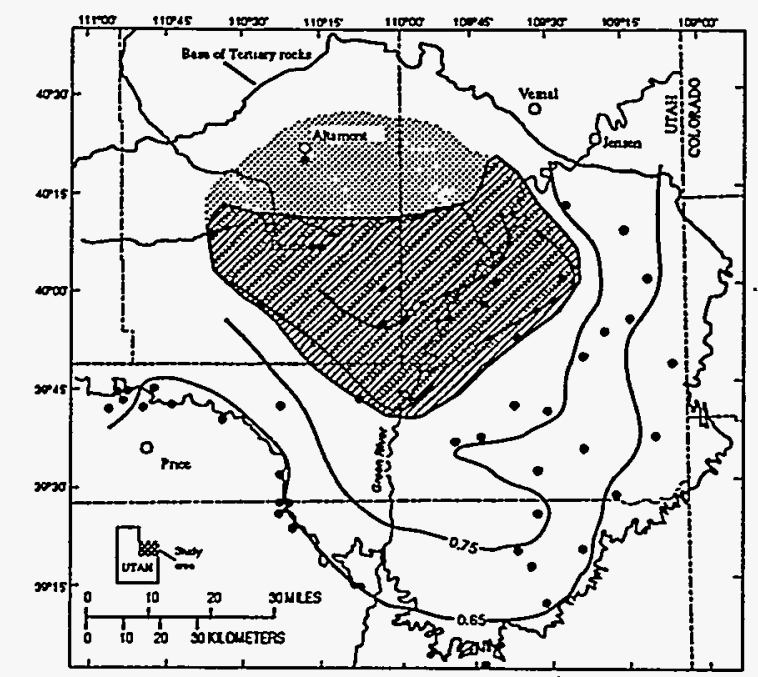

Play 2018: Basin flank Gas-Saturated Mesaverde $15,000 \mathrm{ft}$

D Aros o Play 2018: Mosavado Group gav-caluratod rocorvoizs al diling dophe noar and loss than 15,000 A. Mosaverde Group straba hdude ho Rim Rock, Castegate, and Sego Sends bones, and the Bleckhawk, Tusctier, Farrer, Prike Piver, and Host on Formsitions.

Area of maxdmum gas goneraston trom Typo ill orgahie matter noar tho base $\alpha$ ho Hozeverdo Group (Ros $1.10 \%$.

- contrd poht for mescarros of vitinite reloctance that tolato wo tis play

\section{Considerations for Play 2018 (Mesaverde flank)}

* Part of a classic basin-centered gas-saturated accumulation with current gas generation in the basal part of the Mesaverde Group. There are few wells. Most wells penetrate upper the Mesaverde only but some reach underlying strata. Economic viability of play is likely to be very dependent upon permeability in natural open fractures systems.

* A continuous-gas accumulation is not maintained at depths less than $3000 \mathrm{ft}$.

* Areal extent of sandstone reservoir bodies on outcrop consistent with 80 acre or less spacing

* Likely to be overpressured over much of the play area but nature and extent of fluid-pressure regime is not well constrained. Part of play is in major generation envelope and gas is migrating away from source strata but at a rate slower than recharge.

* Updip limit is coincident with thermal maturity $\left(R_{0}=1.1\right)$ in the lower part of the Cretaceous Mesaverde Group. Downdip limit is arbitrary and is drawn at $15,000 \mathrm{ft}$ where the quality of source and reservoir rocks in less certain but likely to be lower.

* Existing EUR distribution may not reflect full potential of section. EUR distributions for 1) the general area of Mesaverde continuous-phase gas accumulations in the Piceance basin, and 2) the Mesaverde continuous-phase gas accumulations in the Piceance basin near Naval Oil Shale Reserves $1 \& 3$ are used to form a composite Mesaverde EUR distribution for plays 2018 (Mesaverde flank) and 2020 (deep basin center Mesaverde).

* Success ratio of 0.66 is increased from 0.25 determined primarily from uppermost strata to reflect entire section

* Minimum number of untested cells assumes that reservoir quality will be limited to shallower, less thermally mature, and fractured reservoirs directly under the existing Natural Buttes gas field.

* Maximum number of untested cells includes much of the area of the play 2020 (deep basin-centered Mesaverde $>15,000$ $\mathrm{ft}$ ) on the basis that its attributes may not be worse than Mesaverde $<15,000 \mathrm{ft}$. Also, play may extend south into area of play 1019 (Mesaverde transition). 


\section{USGS-DOE TIGHT GAS ASSESSMENT}

\section{DATA FORM FOR ASSESSMENT OF CONTINUOUS-TYPE ACCUMULATIONS}

Province Geologist: Fouch/Schmoker

Province Name, No.: Uinta-Piceance (20)

Date: 7/18/94_Play Name, No.:_Basin Flank Mesayerde (Uinta) (2018)

Play Probability (0-1.0) (II A): 1.0

Stop here if play does not exceed 0.10 (II B)

Cells (III) $\quad$ Cell Size (III A1): $160 \quad$ acres;
Area of Play (III A2): $1533 \mathrm{mi}^{2}$

$.25 \mathrm{mi}^{2}($ acres/640)

No. of productive cells (III B): 25

Total no. of cells (III A3): 6132

No. of untested cells (III D): 6019 50th fractile

Minimum possible number of untested cells (III E1): $\quad 334$ 100th fractile

Maximum possible number of untested cells (III E2): 11458 Oth fractile

Success ratio (0-1.0) (IV): .60

EUR probability distribution $\left(\mathrm{V}^{*}\right)$ :

Minimum

Fractile: $\quad 100$ th $\quad(95$ th $)$

EUR (BO or

MMCF)

$0 \quad(76)$

(75th)

Median

50th

(25th)

(5th)

N.ax

$\begin{array}{llll}200 & 900 \quad(1600) & (2600) & 4000\end{array}$

Notes: See play 2015

Total number of wells that meet screening criteria:

Total number of wells used in the EUR Distribution:

Calculation of EUR: See discussion for play 2015. 


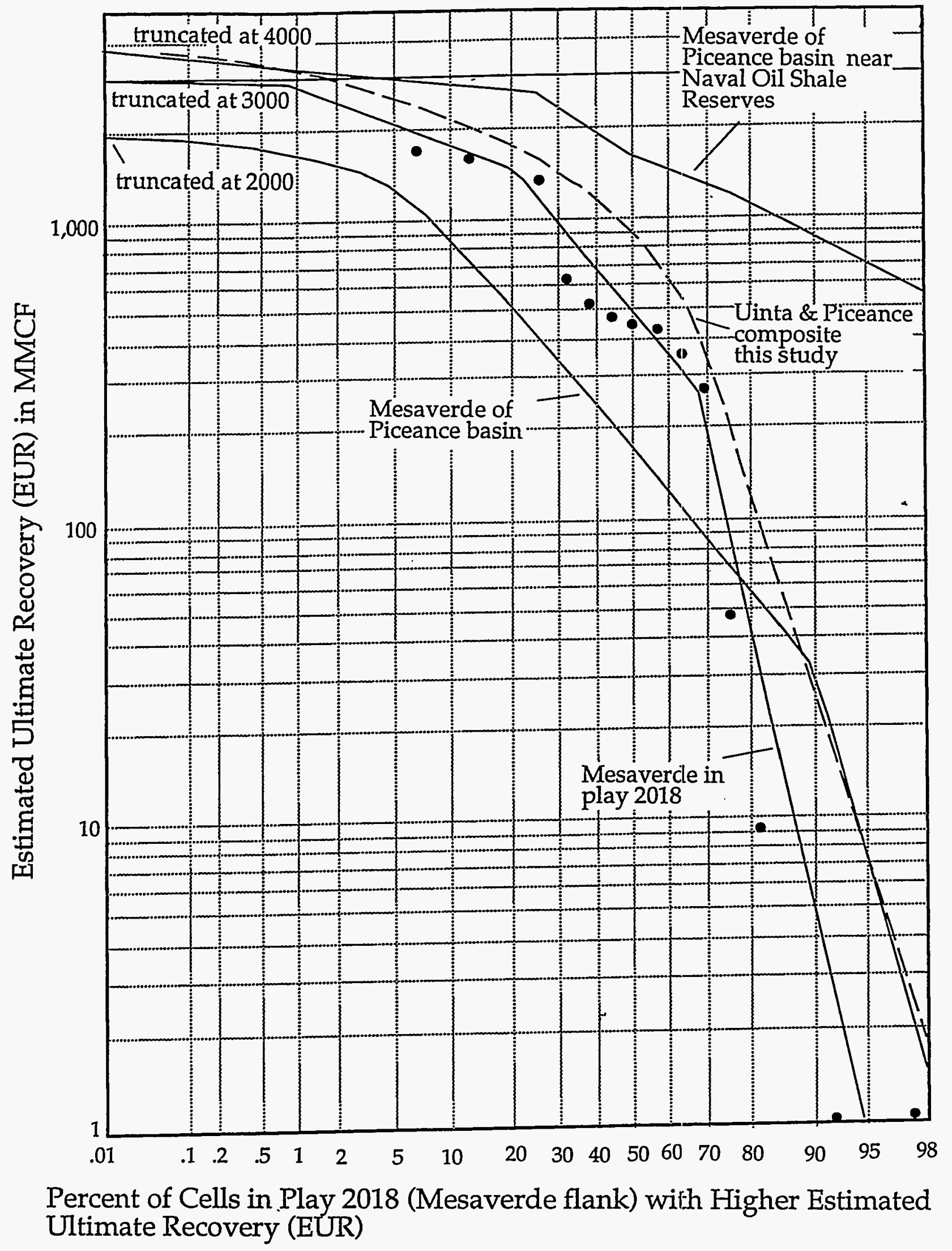


Play 2019 Upper Cretaceous Mesaverde Group Gas/Water Transitional (mixed gas-saturated and some zones with gas/water contacts

Mesaverde, Castlegate, Rim Rock, Sego, Tuscher, Farrer, Buck Tongue, Blackhawk, Price River, Cretaceous undifferentiated, Neslen, Bluecastle

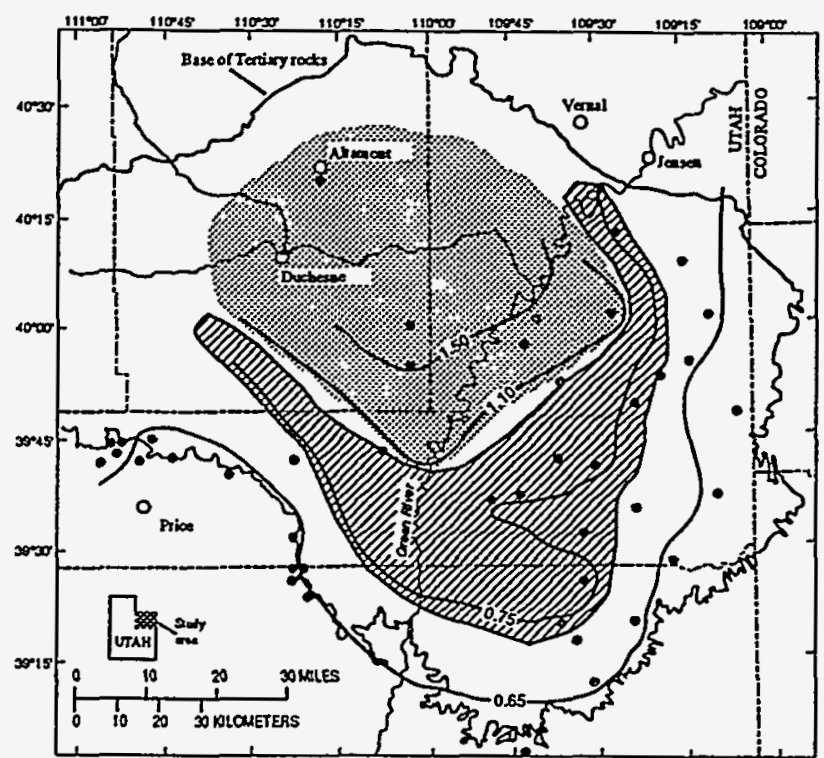

Play 2019: Cretaceous Mesaverde Gas-Water Transitional

Dea of Play 2019 : Mesaverde Group reservols at drilling depths near and less than 15,000n. Mosaverde Group strata heiude the Rim Rock, Castiogate, and Sego Sandstones, and the Elackhakk. Tuscher, Farrer, Prico River, and Nesion Formations. Contains mbed water and gasboaring strata.

Area of maximum gas generation from Type III orgainke matter near the base of the Mesaverdo Group (Ro > 1.10\%)

- Control point for measures of vitrinire renoctance that relate to this play

\section{Considerations for Play 2019 (Mesaverde transition)}

* Play is located at the updip margin of a classic basin-centered gas in the MesaverdeGroup. The plays consists of mixed stratigraphic and structural accumulations of gas in sandstone reservoirs of the Upper Cretaceous Mesaverde Group.

* Free water seems to coexists with zones of continuous gas saturation. Over much of area gas is found on structural highs and strata are water-bearing in lows. However, toward the northern and lower limits of the play, gas-saturated strata are found in structural high and low positions.

* Play contains reservoirs whose matrix permeability commonly exceeds $0.1 \mathrm{md}$. (tight) but other potential saturated reservoirs are much less permeable $(<0.1 \mathrm{md}=$ tight). Economic viability of play is likely to be very dependent upon permeability in natural open fractures systems.

* Likely to beoverpressured over much of the play area butnature and extent of fluid-pressure regime is largely uncertain.

* Updip limit is arbitrary and is drawn at $R_{m} 0.7$ where much of the section is water-bearing.

* Few wells in play area and they tend to penetrate only the uppermost Mesaverde strata. Stratigraphy and sedimentology of reservoir and source rock units largely inferred from sparse seismic data and from subsurface and surface control points outside play area. Existing EUR distribution may not reflect full potential of section. EUR distributions for 1) the general area of Mesaverde continuous-phase gas accumulations in the Piceance basin, and 2) the Mesaverde continuous-phase gas accumulations in the Piceance basin near Naval Oil Shale Reserves 1 \& 3 are used to form a composite Mesaverde EUF distribution for plays 2018 (Mesaverde flank) and 2020 (deep basin center Mesaverde). 
* Areal extent of sandstone reservoir bodies on outcrop is consistent with 80 acre or less spacing

* EUR distribution for play is difficult to determine because of the transition from continuous-phase to mixed types of accumulations. In this study we use a distribution drawn from wells across the study area as a suitable approximation of the mixed population.

* Assessment methodology described in this report for continuous saturation accumulations is used for this play even though some areas and strata of play consists of mixed stratigraphic and structural accumulations that are both water and gas bearing. As a result spacing for play will vary by field and spacing variations are used to establish maximum and minimum numbers of untested cells.

* Minimum number of untested cells assumes that most of the accumulations in the play will utilize 640-acre spacing but that most of the play is saturated.

* Maximum number of untested cells assumes that most of the accumulations in the play will utilize 40-acre spacing and that most of the play is saturated.

\section{USGS-DOE TIGHT GAS ASSESSMENT \\ DATA FORM FOR ASSESSMENT OF CONTINUOUS-TYPE ACCUMULATIONS}

Province Geologist:_Tom Fouch

Province Name, No.: Uinta-Piceance

Date:_2/25/94

Play Name, No.: Mesayerde Gas-Water Transitional, 2019

(codes in parenthesis, such as IV B, refer to the procedure outline)

160 records at $1 \mathrm{t} 160$ acre spacing $=160$ cells tested

Play Probability (0-1.0) (II A): 1

Stop here if play does not exceed 0.10 (II B)

Cells (III)

Cell Size (III A1): $160(640-40)$ acres; $\mathrm{mi}^{2}$ (acres/640)

Area of Play (III A2): $1761 \mathrm{mi}^{2}$

Total no. of cells (III A3): 7044

No. of productive cells (III B): 41

No. of untested cells (III D): $\frac{6884}{60 \text { th fractile }}$

Minimum possible number of untested cells (III E1): 1721 100th fractile

Maximum possible number of untested cells (III E2): 27.536 Oth fractile

Success ratio (0-1.0) (IV): $\quad .27$

EUR probability distribution $\left(\mathrm{V}^{*}\right)$ :

\begin{tabular}{|c|c|c|c|c|c|c|c|}
\hline & Minimum & & & Median & & & $\operatorname{Max}$ \\
\hline O or & & (95th) & (75th) & & (25th) & (5th) & \\
\hline $\mathbb{M}$ & 0 & $(0)$ & $(25)$ & 380 & $(750)$ & (1950) & 3000 \\
\hline
\end{tabular}

Notes: See notes for play 2015.

Total number of wells that meet screening criteria: $\quad 30$

Total number of wells used in the EUR Distribution: 25

Calculation of EUR: See play 2015. 


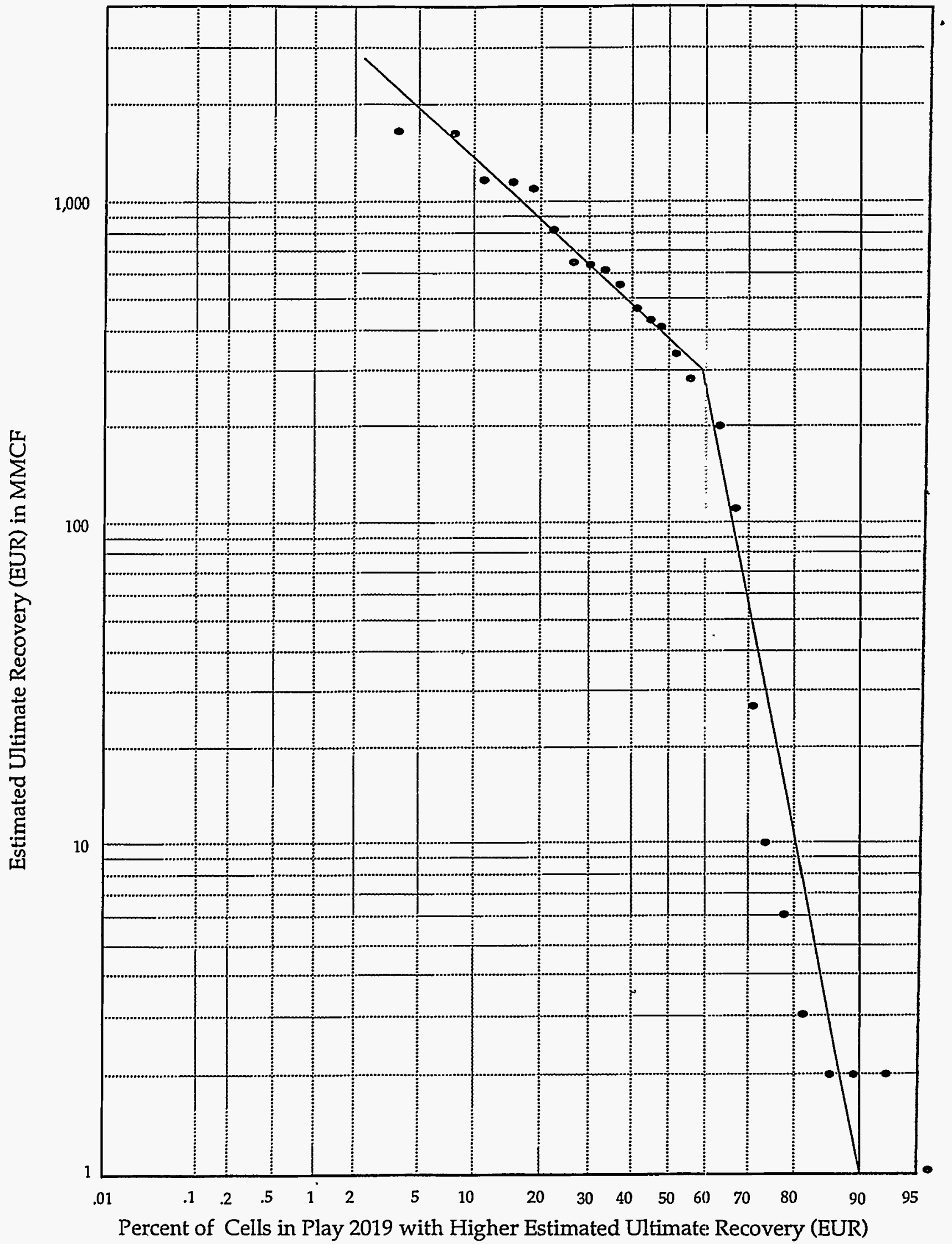




\section{Deep Basin Synclinal Axis Upper Cretaceous Mesaverde Group: Gas Saturated > , $15,000 \mathrm{ft}$}

Mesaverde, Castlegate, Rim Rock, Sego, Tuscher, Farrer, Buck Tongue, Blackhawk, Price River, Cretaceous undifferentiated, Neslen, Bluecastle

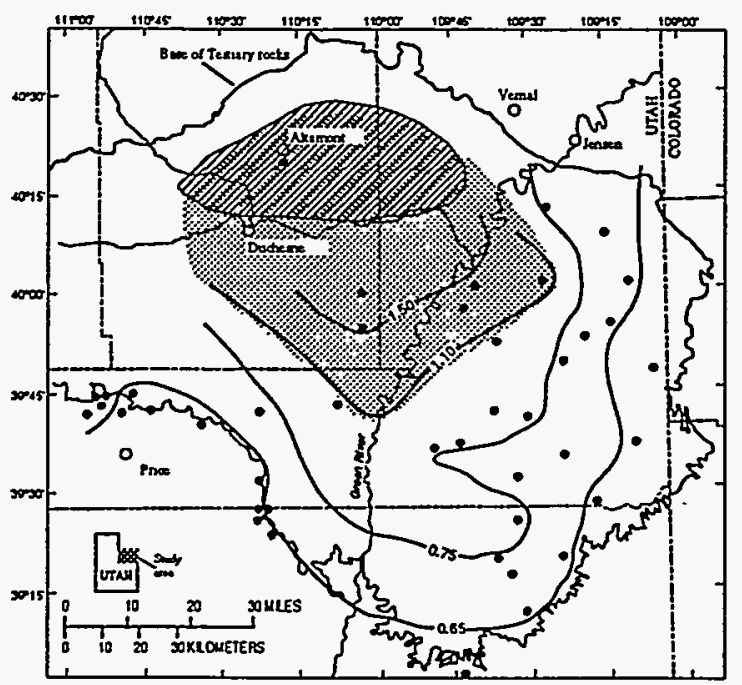

Play 2020: Gas-Saturated Deep Synclinal Low: Cretaceous Mesaverde

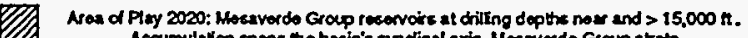

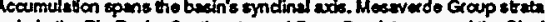

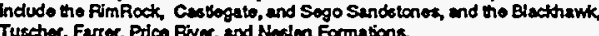

Noa $\alpha$ maxdmum gat generation forn Typo III orgainic mator near the base

of tho Mtoteverdo Grop $($ Ro $>1.10 \%)$.

- Contol polnt for mosecur es of vitinito redectenco that rolate bo tis play

\section{Considerations for Play 2020 (deep basin-centered Mesaverde $>15,000 \mathrm{ft}$ )}

* Part of a classic basin-centered gas-saturated accumulation with current gas generation in the Mesaverde Group. Play is in generation envelope and gas is migrating away from source but at a rale slower than recharge. Economic viability of play is likely to be very dependent upon permeability in natural open fractures systems.

* A continuous-gas accumulation is not maintained at depths less than $3000 \mathrm{ft}$.

* Likely to be overpressured over much of the play area but nature and extent of fluid-pressure regime is largely speculative.

* Southern updip limit is arbitrary and is drawn at $15,000 \mathrm{ft}$ where the quality of source and reservoir rocks in less certain than in play 2018 (Mesaverde flank $<15,000 \mathrm{ft}$ ). Western boundary of play is very uncertain. Northern and eastern limits are established near steeply dipping beds at the basin's flanks.

* The play is essentially untested and there are few wells in play area. Of those, they tend to penetrate only the uppermost Mesaverde strata. Stratigraphy and sedimentology of reservoir and source-rock units largely inferred from sparse seismic data and from subsurface and surface control points outside the play area.

* Existing EUR distribution may not reflect full potential of section. EUR distributions for 1) the general area of Mesaverde continuous-phase gas accumulations in the Piceance basin, and 2) the Mesaverde continuous-phase gas accumulations in the Piceance basin near Naval Oil Shale Reserves 1 \& 3 are used to form a composite Mesaverde EUR distribution for plays 2018 (Mesaverde flank) and 2020 (deep basin centers Mesaverde).

* Areal extent of sandstone reservoir bodies on outcrop consistent with 80 acre or less spacing but primary cell size of 160 acres used in play 2018 is applied due to lack of any information on reservoir and fracture distribution.

* Success ratio of 0.2 was deterrmined primarily from the few deep wells in basin. It is lower than the 0.6 ratio used for play 2018 on the basis that reservoir quality and fractures will deteriorate below $15,000 \mathrm{ft}$ so that many more tests will be very poor producers. 
* Minimum number of untested cells assumes that reservoir quality will be limited to shallower strata near the 15,000, ft level.

* Maximum number of untested cells assumes that the plays poor success ratio (0.2) will extend updip into the basin-flank play 2018.

\section{USGS-DOE TIGHT GAS ASSESSMENT \\ DATA FORM FOR ASSESSMENT OF CONTINUOUS-TYPE ACCUMULATIONS}

Province Geologist:_ Fouch/Schmoker

Province Name, No.: Uinta-Piceance (20)

Date: 7/25/94_Play Name, No.:Deen sunclinal Mesaverde (Uinta) (2020)

(codes in parenthesis, such as IV B, refer to the procedure outline)

Play Probability (0-1.0) (II A): 1.0

Stop here if play does not exceed 0.10 (II B)

Cells (III)

Cell Size (III A1): $160 \quad$ acres;

Area of Play (III A2): $805 \mathrm{mi}^{2}$

$.25 \quad \mathrm{mi}^{2}(\operatorname{acres} / 640)$

Total no. of cells (III A3): 3220

No. of productive cells (III B): 1

No. of untested cells (III D): $\frac{1}{3213}$ 50th fractile

Minimum possible number of untested cells (IIIE1): 528 100th fractile

Maximum possible number of untested cells (III E2): 4913 0th fractile:

(.14)

Success ratio (0-1.0) (IV): 0.20

EUR probability distribution $\left(\mathrm{V}^{*}\right)$ :

\begin{tabular}{|c|c|c|c|c|c|c|c|}
\hline & Minimum & & & Median & & & $\operatorname{Max}$ \\
\hline $\begin{array}{l}\text { Fractile: } \\
\text { EUR (BO or }\end{array}$ & 100 th & (95th) & (75th) & 50 th & (25th) & (5th) & Oth \\
\hline MMCF) & 0 & $(76)$ & $(200)$ & 900 & $(1600)$ & $(2600)$ & 4000 \\
\hline
\end{tabular}

Notes: Petroleum Information lists one well for the Mesaverde Group $>15,000$ in the play area. We used wells from play 2018-ie Mesaverde wells deeper than $15,000 \mathrm{ft}$.

Total number of wells that meet screening criteria:

Total number of wells used in the EUR Distribution:

6

Calculation of EUR: See play 2018 


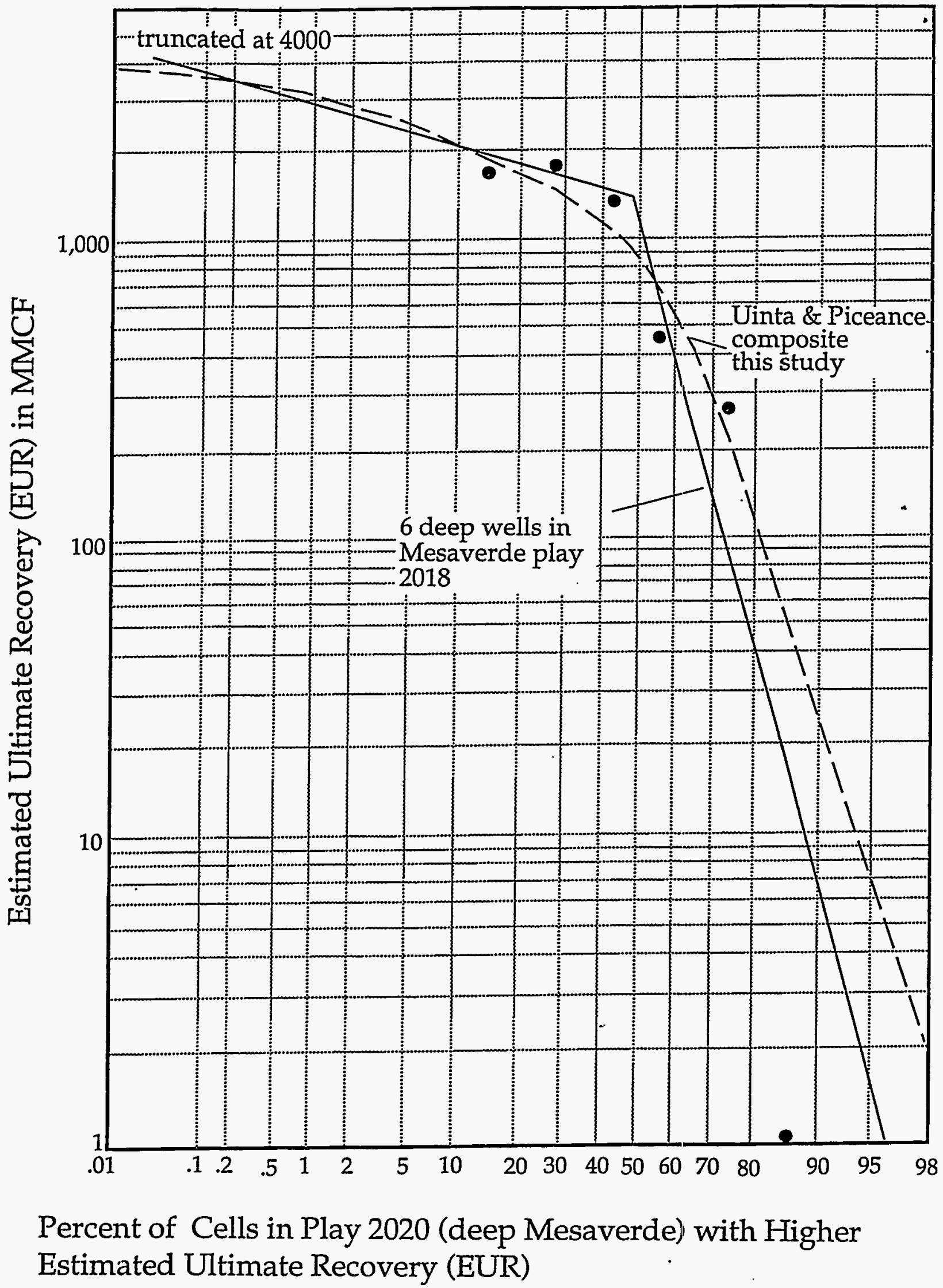


This page intentionally left blank. 
APPENDIX B

GUIDELINES FOR COMPLETING DATA FORM FOR ASSESSMENT OF . CONTINUOUS-TYPE ACCUMULATIOINS 
This page intentionally left blank. 


\section{Objective}

To estimate potential additions to gas and oil reserves in unconventional hydrocarbon accumulations defined as "continuous-type" gas or oil accumulations, not significantly affected by hydrodynamic influences, for which assessment methodologies based on sizes and numbers of fields are not appropriate.

\section{Selected Definitions}

cell-a subdivision of a play with an area or size (acres, or $\mathrm{mi}^{2}=$ acres $/ 640$ ) equal to the typical spacing expected for wells of the play.

play probability-the probability (0-1.0) that untested cells of a play are capable of producing at least $1 \mathrm{MMBO}$ or $6 \mathrm{BCF}$ non-associated gas.

\section{Procedure}

I. Represent the continuous-type accumulation by plays.

A. Define a play or plays sufficiently homogeneous so that each play can be reasonably characterized by a single play probability, cell size, success ratio, and estimated ultimate recovery (EUR) probability distribution for productive cells.

B. Map each play. Play boundaries must be concisely drawn because the assessment will depend strongly on the area of the play.

C. Identify each play as either a gas play or an oil play. A cutoff of $20,000 \mathrm{CF} / \mathrm{BO}$ is used to distinguish gas plays from oil plays.

II. Risk each play.

A. Estimate the play probability (see definition above).

B. If play probability does not exceed 0.10 , the play will not be assessed and following items do not need to be evaluated.

III. Estimate number of untested cells in play. (\# untested cells = \# total cells - \# productive cells \# nonproductive cells)

A. Determine total number of cells.

1. Estimate cell size (see definition on previous page), using data from an analog play if necessary.

2. Measure area of play $\left(\mathrm{mi}^{2}\right)$.

3. Total number of cells $=$ area of play $\left(\mathrm{mi}^{2}\right) / \operatorname{cell}$ size $\left(\mathrm{mi}^{2}\right)$

B. Count number of productive cells. A productive cell contains one or more wells for which production from the play is reported. Because a cell can contain several wells, the number of productive cells might be less than the number of productive wells.

C. Count number of nonproductive cells. A nonproductive cell contains one or more wells that evaluated the play, none of which was productive in the play. Analogous to III B, the number of nonproductive cells might be less than the number of nonproductive wells.

D. Calculate number of untested cells using above formula.

E. Estimate uncertainty associated with number of untested cells in the play. Assuming the calculation of IIID represents a median value:

1. What is the minimum possible number of untested cells?

2. What is the maximum possible number of untested cells? 
IV. Estimate success ratio for untested cells of play. (Success ratio = fraction of untested cells (0-1.0), expected to be productive.)

A. One approach is to calculate success ratio based on existing drilling, as the number of productive cells (IIIB) divided by the total number of cells evaluated (productive plus nonproductive(IIIC)).

B. If play has no productive cells (a hypothetical play), or play is insufficiently tested to establish a realistic success ratio, or existing drilling results do not represent the play as a whole:

1. Estimate success ratio using data from an analog play.

2. Or, estimate success ratio from geologic concepts regarding the play.

Explanatory note - the combination of success ratio and number of untested cells yields the number of productive, untested cells in the play.

V. Establish an estimated ultimate recovery (EUR) probability distribution for productive, untested cells of play. (Units are BO or MMCF.)

A. Select wells that form a sample set representative of productive, untested cells of the play. Use wells from an analog play if necessary.

B. Examine production data from wells of the sample set. These data constitute a reference model for production from productive, untested cells. Be wary of production data that are atypical of the productive, untested cells of the play (unusual engineering, periods of curtailment, spacing less than cell size, sweet spot not likely to occur elsewhere, etc.).

C. Based on B (above), supply estimates to establish anEUR probability distribution for productive, untested cells of the play:

1. What is the median EUR?

2. What is the maximum EUR? (Remember that a sample set of relatively few cells may not include the maximum EUR of the play.)

3. The minimum EUR is usually taken as zero, for which then is $100 \%$ probability that a cell's EUR will be higher.

At this point, fundamental elements of the assessment are established. Potential reserve additions are calculated by combining the play probability, number of untested cells, success ratio, and EUR probability distribution.

VI. Ancillary data for play.

A. Information needed to assess co-products:

1. If an oil play, what is the expected ratio of total gas to oil (GOR) (CF/BO)?

2. If a gas play, what is the expected ratio of oil and natural gas liquids to total gas (BO/ MMCF)?

B. Estimate depths ( $\mathrm{ft}$ ) of untested cells:

1. What is the median depth?

2. What is the minimum depth?

3. What is the maximum depth?

C. What fraction (0-1.0) of untested cells will be tested by wells originally targeted:

1. For the play?

2. For a deeper horizon?

3. For a shallower horizon?

D. Estimate API gravity (degrees) of oil and/or condensate in the play.

E. If a gas play, approximately what fraction of the play (0-1.0) carries a "tight" FERC designation?

F. Approximately what fraction of the play (0-1.0) consists of lands off-limits to drilling (wildemess areas, national parks, cities, etc.)? 